i)as 2hicues

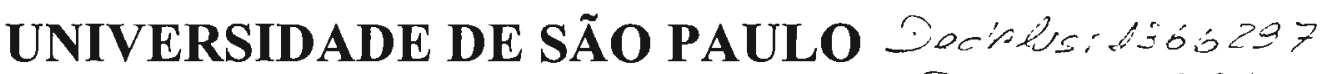 DEDC: 263?: INSTITUTO DE QUÍMICA Tonminsi o.
}

\section{POLIMORFISMO DO CÓDON 72 DO GENE $p 53$ E RISCO DE INFECÇÕES PERSISTENTES POR PAPILOMAVÍRUS HUMANO (HPV) E NEOPLASIA DO COLO UTERINO}

\author{
Tatiana Rabachini \\ Dissertação de Mestrado
}

Orientadora: Dra. Luisa Lina Villa

SÃO PAULO

20 de dezembro de 2002 


\section{INSTITUTO DE QUIMICA \\ Universidade de Săo Paulo 20675 \\ UNIVERSIDADE DE SÃO PAULO \\ INSTITUTO DE QUÍMICA}

\section{POLIMORFISMO DO CÓDON 72 DO GENE $p 53$ E RISCO DE INFECÇÕES PERSISTENTES POR PAPILOMAVÍRUS HUMANO (HPV) E NEOPLASIA DO COLO UTERINO}

Tatiana Rabachini

Dissertação de Mestrado

Orientadora: Dra. Luisa Lina Villa

SÃO PAULO

20 de dezembro de 2002 


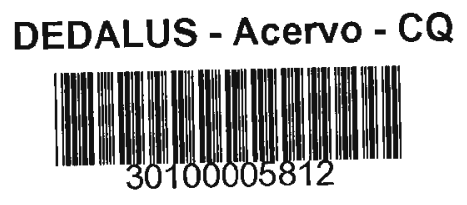

Ficha Catalográfica

Elaborada pela Divisão de Biblioteca e

Documentação do Conjunto das Químicas da USP.

Rabachini, Tatiana
Polimorfismo do códon 72 do gene p53 e risco de infecções
persistentes por papilomavírus humano (HPV) e neoplasia do
colo uterino / Tatiana Rabachini. -- São Paulo, 2002.
$120 p$. 


\section{"Polimorfismo do Códon 72 do Gene p53 e Risco de Infecções Persistentes por Papilomavírus Humano (HPV) e Neoplasia do Colo Uterino"}

\section{TATIANA RABACHINI}

Dissertação de Mestrade submetida ao Instituto de Química da Universidade de Săo Paulo como parte dos requisitos necessários à obtenção do grau de Mestre em Ciências - Área: Bioquímica.

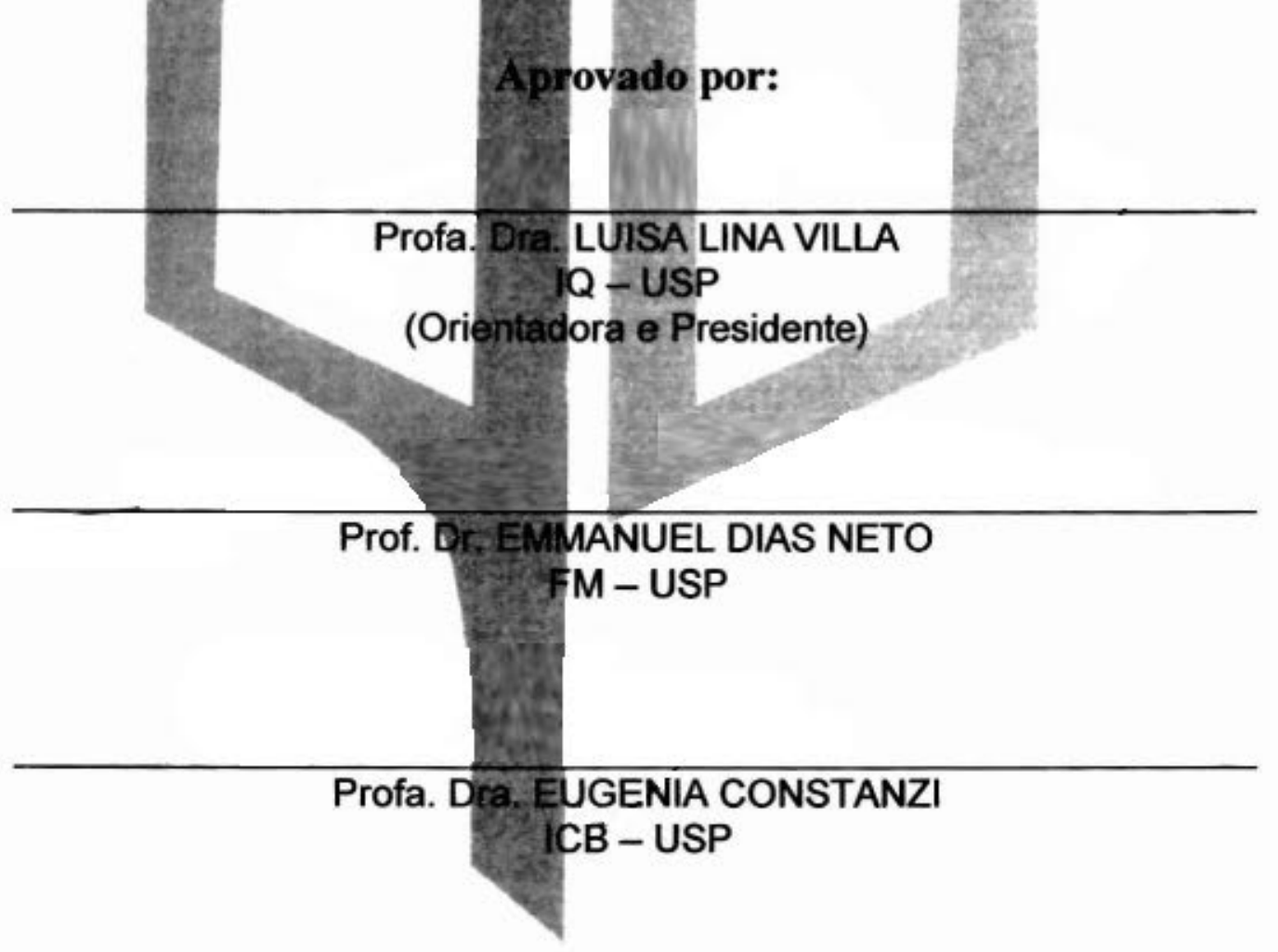


$O$ verdadeiro ato da descoberta não consiste em encontrar novas terras, mas sim, em vê-las com novos olhos. (Marcel Proust) 


\section{DEDICATÓRIA}

Aos meus pais,

Terezinha e Luiz,

por me ensinarem que quem tem AMOR, tem TUDO! 


\section{AGRADECIMENTOS}

A Deus, por tudo!

Aos meus pais, Terezinha e Luiz, por serem os meus maiores professores. Vocês me ensinaram não só os primeiros passos, as primeiras palavras...vocês me deram exemplos de que com coragem e força de vontade eu poderia e conseguiria chegar lá. Obrigada pelo seu exemplo de vida, obrigada pela nossa família, obrigada pela nossa união e, principalmente, por todo amor que vocês me deram. Vocês são a minha maior riqueza.

Ao meu querido Rogério, por fazer de sua vida a nossa vida. Como eu posso agradecer toda a felicidade que você me trouxe. Obrigada por ser meu melhor amigo. Obrigada por ser meu maior companheiro. Obrigada pela compreensão e respeito e principalmente, obrigada por me deixar fazer da minha vida a nossa vida.

À minha orientadora Dra. Luisa Lina Villa, por quem eu cultivo uma extensa admiração. Sua alegria contagiante e seu árduo profissionalismo a fazem não só um ser humano maravilhoso, mas um exemplo para todos aqueles que tem a ciência como paixão. Querida Dra. Luisa, obrigada por me deixar fazer parte da "nossa família". Obrigada por ter sido a minha orientadora perfeita.

Aos meus queridos irmãos: Wagner (Wá), Tarcísio (Ci), Régis (Ré) e Taís, minha segunda irmã (cunhada) Eliane, meu quarto irmão ("cunhado") Giovani e minhas sobrinhas: Bruna, Tamíris e Gabriela por fazerem minha vida mais alegre. Apesar da distância, nossa maravilhosa convivência ocupa um lugar especial nas minhas mais doces memórias. Obrigada por simplesmente existirem, vocês são essenciais. 
Ao Instituto Ludwig de Pesquisa sobre o Câncer, na pessoa do diretor desta Instituição Prof. Dr. Ricardo Renzo Brentani, pela oportunidade de poder dispor do apoio desta instituição para realizar este trabalho.

Ao Dr. Eduardo Franco e à Anita Koushik pelas análises estatísticas que constam neste trabalho.

A minha grande família virologia, por serem mais do que grandes amigos. Cada um de vocês tem um significado especial na minha vida e tenho certeza de que as lembranças desses maravilhosos anos de convivência irão permanecer no meu coração e na minha memória para sempre. Agradeço à Adriana, pela sua maneira tão doce de ser tão prestativa; à Andréa, por ser a minha companheira de "taurinisses"; à Carol, que mesmo longe consegue deixar a nossa vida mais divertida; ao Enrique, por me ensinar sempre, mesmo que sejam meigas palavrinhas em castelhano; à Isa, pelo seu carisma; a Jane, pela herança do $p 53$; ao Joãozinho, pelas empadinhas e comidinhas fora de hora; à Katy, pela sua inocência tão divertida; à Lara, por ser a minha irmãzinha; à Laura, pelo seu hilário exagero; a Lenice, pelo seu sorriso tão doce; à Maria Cecília, pela sua simpatia; à Mônica, por estar sempre torcendo; à Neide, por ser tão bem humorada; à Paty Sávio, discípula do menino "Poul", companheira de HLA e de boas risadas; a Paty Thomann, por ter sempre a palavra certa na hora certa; ao meu "companheiro" Paulinho, que embora longe, deixou a sua marca nos nossos corações; a Raquel, pela paciência ao receber minhas intermináveis listas; ao Rodrigo, por ser o "menino" Rodrigo de sempre; ao Rômulo, pela extração de "só mais um" DNA e ao Zé, por contar histórias hilárias, como a do satanás no rádio. A todos vocês, meu muito obrigado. 
Á nossa querida Stella, que através da sua imensa simpatia faz tudo parecer mais simples.

À Dra. Otávia Caballero e ao Ricardo Moura, pelo grande carinho e atenção numa das principais etapas deste trabalho.

À Anna Christina e à Elis, pela inestimável ajuda no seqüenciamento.

Ao Alex, por ser sempre tão prestativo, principalmente numa das etapas deste trabalho.

À toda grande "família Ludwigiana" pelas ajudas constantes e maravilhosa convivência.

A todos os funcionários do Instituto Ludwig, pela efíciência e alegria.

A todos os funcionários da secretaria de pós-graduação do Instituto de Química, por serem tão prestativos.

Ao pessoal da Triaton informática, por nos socorrerem em momentos de pânico.

À minha madrinha Jisélia e meu padrinho Nivaldo por sempre estarem torcendo.

Às minhas grandes amigas e companheiras de aluguel: Inês e Maria Fernanda, que sabem que a amizade é mais importante do que qualquer outra coisa. À Dalva por sempre trazer alegria para o nosso lar.

À FAPESP e NIH-USA pelo apoio financeiro. 


\section{ÍNDICE}

INTRODUÇÃ

1. O CARCINOMA DO COLO UTERINO . . . . . . . . . . . . . . 1

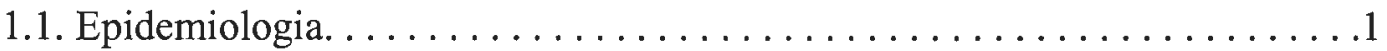

1.2. Histopatologia. . . . . . . . . . . . . . .

1.3. Fatores de Risco. . . . . . . . . . . . . . . . . . . . . . . 3

2. O PAPILOMAVÍRUS HUMANO ................... 5

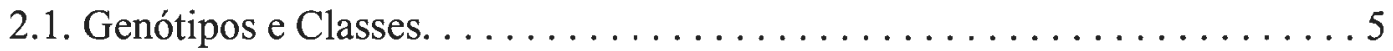

2.2. Associação com Carcinoma do Colo Uterino. . . . . . . . . . . . . . 5

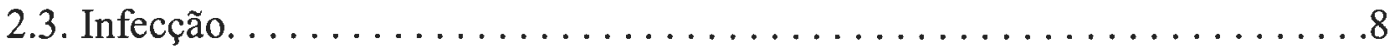

2.4. História Natural. . . . . . . . . . . . . . . . . . . . . .9

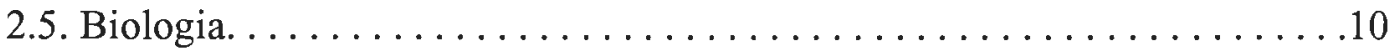

2.6. Proteínas Virais. . . . . . . . . . . . . . . . . . . . . . . . . 12

2.7. Potencial Oncogênico. . . . . . . . . . . . . . . . . . . . . . . . 16

2.8. Fatores que Afetam a Progressão Maligna. . . . . . . . . . . . . . . 20

2.9. Fatores Coadjuvantes à Oncogenicidade do HPV . . . . . . . . . . . 22

3. A INTERAÇÃO ENTRE p53 E E6. . . . . . . . . . . . . . . . 23

3.1. A Degradação de p53 Mediada por E6 . . . . . . . . . . . . . 23

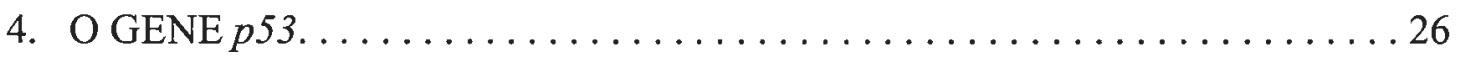

4.1. Histórico e Aspectos Gerais. . . . . . . . . . . . . . . . 26

4.2. Envolvimento na Carcinogênese Humana. . . . . . . . . . . . . . . 27

4.3. Estrutura e Função. . . . . . . . . . . . . . . . . . . . . . . 29

4.4. Polimorfismo do Códon 72 do Gene $p 53 \ldots \ldots \ldots \ldots \ldots \ldots \ldots \ldots$

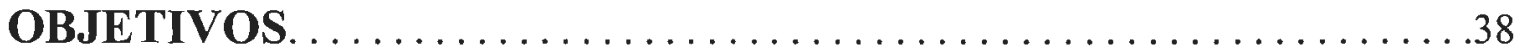

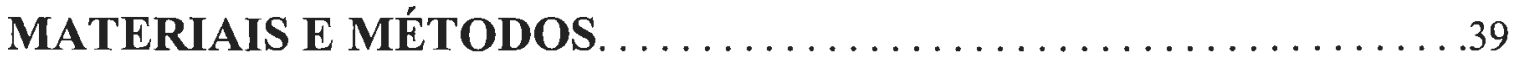

1. AMOSTRAS CLÍNICAS. . . . . . . . . . . . . . . . . . . . . . . 39

2. TESTE PARA HPV . . . . . . . . . . . . . . . . . .

2.1. Isolamento de DNA dos Esfregaços do Colo Uterino. . . . . . . . . . . 41 
3. DETERMINAÇÃO DO GENÓTIPO DE $p 53$ PARA O CÓDON $72 \ldots \ldots \ldots . .42$

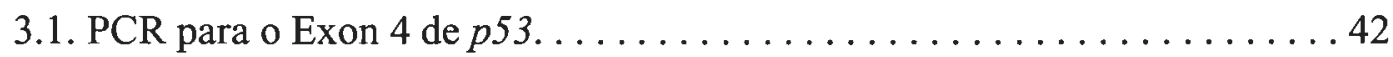

3.2. Hibridização Alelo-específica. . . . . . . . . . . . . . . . . 45

3.3. DHPLC . . . . . . . . . . . . . . . . . . . . . . . . . 47

3.4. RFLP. . . . . . . . . . . . . . . . . . . . . . . . . . .

3.5. Seqüenciamento Direto. . . . . . . . . . . . . . . . . . . . 51

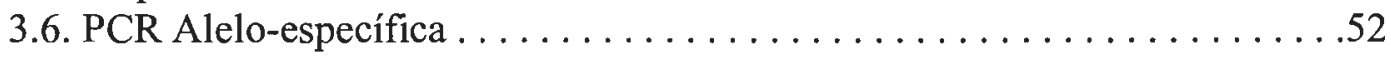

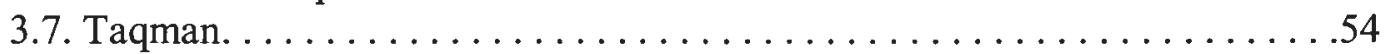

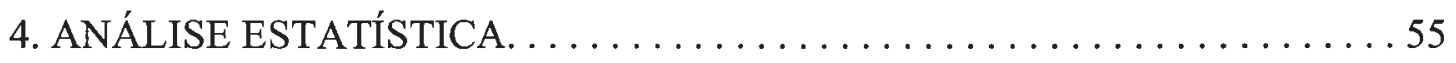

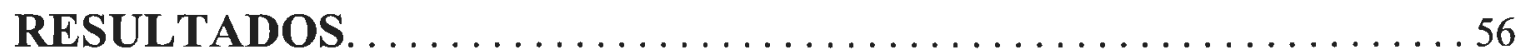

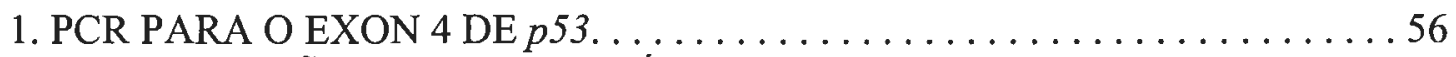

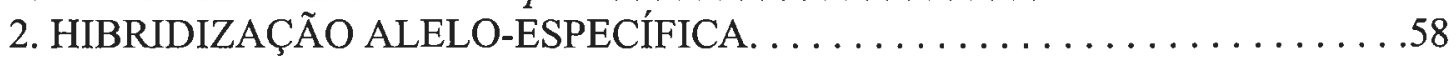

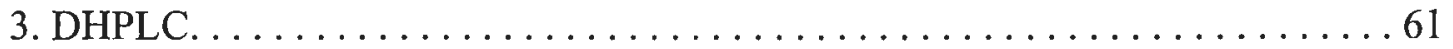

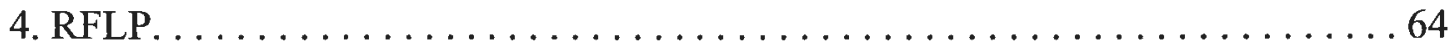

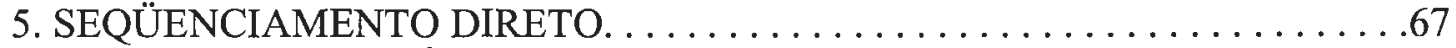

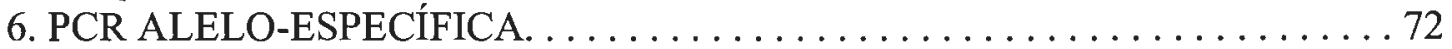

7. COMPARAÇÃO DE METODOLOGIAS. . . . . . . . . . . . . . . . 72

8. CORRELAÇÃO ENTRE O POLIMORFISMO DO CÓDON 72 DE $p 53$, HPV E LESÕES PRECURSORAS DO CARCINOMA DO COLO UTERINO. . . . . . . . 75

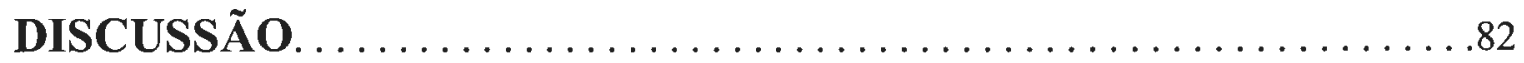

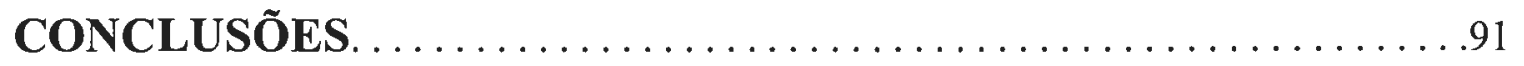

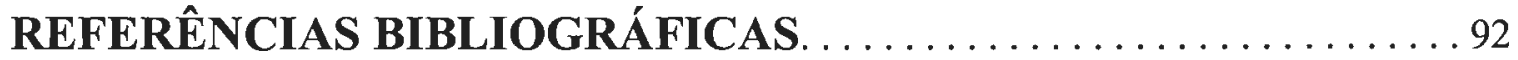




\section{LISTA DE FIGURAS}

Figura 1. Mapa físico do genoma do HPV-16, com a região precoce (E), a região tardia (L) e a LCR que corresponde a região regulatória (revisado por VILLA, 1997) . . . . . 11

Figura 2. O ciclo de vida do papilomavírus humano. Para que a infecção seja produtiva, o vírus precisa infectar a camada basal. Isso normalmente ocorre através de microlesões, na pele ou na mucosa. As células infectadas se dividem e se espalham lateralmente. Algumas dessas células progenitoras migram para as camadas diferenciadas suprabasais, onde genes virais serão ativados, o DNA do vírus será replicado e as proteínas do capsômero serão formadas. As particulas virais surgem e são liberadas na superfície da mucosa onde podem infectar tecidos adicionais (Modificado de ZUR HAUSEN, 2002).13

Figura 3. Funções das oncoproteínas E6 e E7 e suas interações com diversos passos envolvidos na imortalização celular. E6 promove a ativação da telomerase e das quinases SRC e a inibição de p53 e Bak. E7 inibe pRB e promove a liberação de E2F resultando na superexpressão de p16INK4a. Esta proteína, por sua vez, também é inativada por E7. E7 também estimula a entrada na fase S e inativa p21 e p27. E6 e E7 cooperam para a imortalização celular e a transformação malígna. E6 previne a apoptose induzida por altos níveis de E2F e E7 impede a inibição de E6 por p16INK4a (Modificado de ZUR HAUSEN, 2002) . . . . . . . . . . . . . . . . . . . . . . . . . . . 17

Figura 4. Fatores relacionados e não relacionados ao HPV que podem induzir a progressão maligna. Fatores de risco virais e não virais estão listados do lado esquerdo da figura. Fatores hormonais ativam os promotores virais e facilitam a imortalização de células infectadas pelo HPV. Agentes mutagênicos influenciam a persistência do DNA do vírus. Estes acentuam a progressão pela modificação celular das cascatas de sinalização que controlam a persistência do HPV, ou levam a um aumento na expressão de oncogenes virais por um efeito dose-resposta destes. Os crescentes níveis de expressão de E6 e E7, por sua vez, resultam num aumento da instabilidade genômica, que promove a progressão das células infectadas a um crescimento invasivo (modificado de ZUR HAUSEN, 2002). . . . . . . . . . . . . . . . . . . . . . . . . 21

Figura 5: A proteína E6 induz a degradação de p53. A enzima E1 promove a ativação da ubiquitina, que é transferida para uma enzima conjudada E2 e esta, transfere o radical ubiquitina para a proteína ubiquitina ligase E3. E6 de HPV se liga a E6-AP, fazendo com que esta passe a ter a capacidade de transferir radicais ubiquitina para p53. p53 poliubiquitinado é degradado pelo complexo proteossomo 26S (Modificado de THOMAS

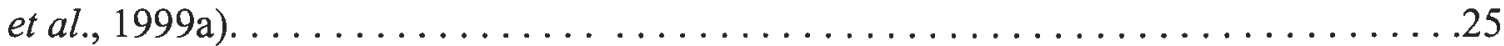

Figura 6: Representação esquemática da estrutura da proteína p53. Nas caixas superiores estão representadas as proteínas celulares e virais que interagem com os seus respectivos domínios (Modificado de MAY e MAY, 1999). . . . . . . . . . . . . . . . . 31

Figura 7. Representação esquemática da formação de heteroduplexes através da formação de heteroduplexes por modulação de temperatura. . . . . . . . . . . . . . 49 
Figura 8. PCR para a deteç̧ão dos alelos de $p 53$. Localização do polimorfismo do códon 72 do exon 4 e as posições dos oligonucleotídeos usados para a deteç̧ão do alelo prolina e arginina. Para a amplificação do alelo arginina (p53Arg) são usados os pares de oligonucleotídeos $\mathrm{p} 53+/ \mathrm{p} 53$ Arg gerando um produto de $141 \mathrm{pb}$. Para a amplificação do alelo prolina (p53Pro) são usados os pares de oligonucleotídeos $\mathrm{p} 53$ Pro/p53-gerando um produto de $177 \mathrm{pb}$ (Modificado de Kaiano et al., 2000). . . . . . . . . . . . . . . . . . . 53

Figura 9. Gel de Agarose 1,5\%, corado por brometo de etídeo, contendo produto de PCR do exon 4 do gene p53 amplificado pelo protocolo padronizado por este trabalho. $\mathrm{Na}$ canaleta 1 foi adicionado o marcador de peso molecular (100 bp). Nas canaletas 2 a 19, foram aplicadas testes e na canaleta 20 o controle negativo da reação. . . . . . . . . 57

Figura 10. Hibridização alelo-específica das amostras submetidas a amplificação do exon 4 de $p 53$. O quadro a esquerda mostra o autoradiograma de uma membrana hibridizada com a sonda p53Arg. O quadro da direita mostra o autoradiograma de uma membrana hibridizada com a sonda p53Pro. A análise em conjunto dessas membranas ilustra o genótipo das amostras aplicadas. A amostra 1A apresenta um perfil compatível com o de uma amostra homozigota para o alelo p53Arg, uma vez que o sinal só aparece no autoradiograma da membrana hibridizada com a sonda p53Arg. A amostra 2A apresenta padrão característico de uma amostra heterozigota para o polimorfismo do códon 72 , uma vez que apresentou sinal de hibridização em ambas sondas utilizadas. A amostra 1B, por sua vez, apresenta padrão compatível com uma amostra homozigota para o alelo p53Pro, uma vez que o sinal só aparece no autoradiograma da membrana hibridizada com a sonda p53Pro. A amostra B5 representa um controle heterozigoto. A amostra B6 representa um controle homozigoto para o alelo p53Arg. A amostra B7 representa um controle homozigoto para o alelo p53Pro. A amostra B8 representa um controle negativo de amplificação. . . . . . . . . . . . . . . . . . . . 59

Figura 11. Freqüências genotípicas dos alelos de p53 do códon 72 , em amostras provenientes de esfregaço de colo de útero de uma amostra do estudo epidemiológico prospectivo Ludwig/McGill. Os espécimes heterozigotos representaram 41,2\% do total de amostras submetidas à hibridização alelo-específica. As amostras homozigotas para o alelo arginina representaram $39,8 \%$ e as amostras homozigotas para o alelo prolina

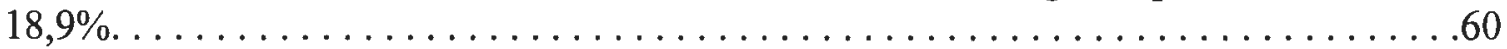

Figura 12. Cromatograma de amostras controles amplificadas e submetidas a primeira triagem por DHPLC. O cromatograma na cor vermelha apresenta o padrão característico de uma amostra heterozigota. Os cromatogramas nas cores amarela e verde apresentam padrão característico de amostras homozigotas. No caso de uma segunda triagem, amostras com genótipo igual ao da amostra controle adicionada neste passo apresentam o perfil cromatográfico visto em amarelo e verde. No caso de uma amostra teste de genótipo diferente ao da amostra controle adicionada neste passo, o perfil cromatográfico é semelhante àquele apresentado em vermelho. . . . . . . . . . . . . . 62 
Figura 13. Freqüências genotípicas dos alelos de p53 do códon 72 , em amostras provenientes de esfregaço de colo de útero do estudo epidemiológico prospectivo Ludwig/McGill. As amostras heterozigotas representaram $42,2 \%$ do total de amostras submetidas à hibridização alelo-específica. Quarenta porcento foram homozigotas para o alelo arginina e $17,5 \%$ para o alelo prolina. . . . . . . . . . . . . . . 63

Figura 14. Gel de Poliacrilamida 8\% corado pela prata contendo produtos de PCR do exon 4 do gene p53 digerido pela enzima BstUI. Na canaleta 0 foi adicionado o marcador de peso molecular (50 pb). Nas canaletas 1, 3, 4, e 9 amostras identificadas como heterozigotas para o polimorfismo do códon 72 do gene p53. Nas canaletas 2,7 e 8 amostras identificadas como homozigotas prolina e nas canaletas 5 e 6 amostras identificada como sendo homozigotas arginina. . . . . . . . . . . . . . 65

Figura 15. Gel de Poliacrilamida $12 \%$ corado pela prata contendo produto de PCR do exon 4 do gene p53 digerido pela enzima $B$ saJI. Na canaleta 0 foi adicionado o marcador de peso molecular $(50 \mathrm{pb})$. Nas canaletas $2,3,4$, e 8 amostras identificadas como heterozigotas para o polimorfismo do códon 72 do gene p53. Nas canaletas 6 e 12 amostras identificadas como homozigotas prolina e nas canaletas $1,5,7,9,10$ e 11 amostras identificadas como sendo homozigotas arginina. . . . . . . . . . 66

Figura 16. Freqüências genotípicas dos alelos de p53 do códon 72 , em amostras provenientes de esfregaço de colo de útero do estudo epidemiológico prospectivo Ludwig/McGill. As amostras heterozigotas representaram 45,3\% do total de amostras submetidas à hibridização alelo-específica. As amostras homozigotas para o alelo arginina representaram $34,3 \%$ e as amostras homozigotas para o alelo prolina $20,4 \%$. . 68

Figura 17. Freqüências genotípicas dos alelos de p53 do códon 72 , em amostras provenientes de esfregaço de colo de útero do estudo epidemiológico prospectivo Ludwig/McGill. As amostras heterozigotas representaram $43 \%$ do total de amostras submetidas à hibridização alelo-específica. As amostras homozigotas para o alelo arginina representaram $40 \%$ e as amostras homozigotas para o alelo prolina $17 \%$. . . 69

Figura 18. Cromatograma das amostras amplificadas para o exon 4 de $p 53$ submetidas ao seqüenciamento direto. O quadro A ilustra uma amostra homozigota para o alelo prolina, o quadro B ilustra uma amostra heterozigota e o quadro C ilustra uma amostra homozigota para $o$ alelo arginina. . . . . . . . . . . . . . . . . 70

Figura 19. Freqüências genotípicas dos alelos de $p 53$ do códon 72 , em amostras provenientes de esfregaço de colo de útero do estudo epidemiológico prospectivo Ludwig/McGill. As amostras heterozigotas representaram $42,6 \%$ do total de amostras submetidas à hibridização alelo-específica. As amostras homozigotas para o alelo arginina representaram $38,7 \%$ e as amostras homozigotas para o alelo prolina $18,7 \%$. . 71 
Figura 20. Gel de poliacrilamida $8 \%$ corado pela prata contendo o produto da amplificação específica para o polimorfismo do códon 72 de $p 53$. Na canaleta 0 foi adicionado o marcador de peso molecular $(50 \mathrm{pb})$. $O$ quadro da esquerda mostra amostras amplificadas com iniciadores específicos para o alelo Arg. O quadro da direita mostra amostras amplificadas com iniciadores específicos para o alelo Pro. A análise em conjunto desses géis ilustra o genótipo das amostras aplicadas. A amostra 1 apresenta perfil compatível com a de uma amostra heterozigota para o polimorfismo do códon 72 , uma vez que apresentou amplificação em ambas reações. A amostra 2 ilustra uma amostra inadequada para amplificação de ambos alelos. A amostra 3 representa uma amostra homozigota para o alelo Arg, uma vez que a amplificação foi específica para o alelo Arg. A amostra 4 representa uma amostra homozigota para o alelo Pro, uma vez que a amplificação foi específica para o alelo Pro. A amostra 5 representa o controle negativo da reação. . . . . . . . . . . . . . . . . . . . . . 73

Figura 21. Freqüências genotípicas dos alelos de $p 53$ do códon 72 , em amostras provenientes de esfregaço de colo de útero do estudo epidemiológico prospectivo Ludwig/McGill. As amostras heterozigotas representaram 34\% do total de amostras submetidas à hibridização alelo-específica. As amostras homozigotas para o alelo arginina representaram $45,4 \%$ e as amostras homozigotas para o alelo prolina $20,6 \%$. 74 


\section{LISTA DE TABELAS}

Tabela 1. Padrão de ciclagem e de reagentes utilizados para amplificação do exon 4 de $p 53$. .

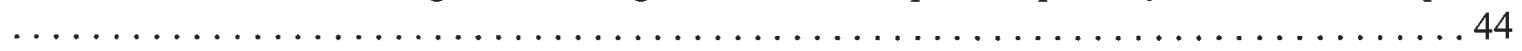

Tabela 2. Condições ideais utilizadas na identificação dos alelos do códon 72 de $p 53$ pelo método de hibridização alelo-específica. . . . . . . . . . . . . . . . . 47

Tabela 3. Enzimas de Restrição utilizadas na digestão do éxon 4 de p53.......... 51

Tabela 4. Condições de digestão ideais para as diferentes enzimas de restrição utilizadas . .51

Tabela 5. Freqüência dos genótipos do códon 72 de $p 53$ nas diferentes metodologias. . . . 75

Tabela 6. Análise de concordância ${ }^{1}$ entre hibridização alelo-específica, DHPLC e Taqman ${ }^{2}$.

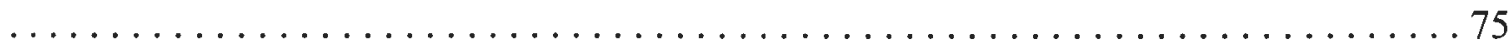

Tabela 7. OR da associação entre o genótipo de p53 e qualquer infecção com HPV de baixo risco oncogênico nas diferentes metodologias utilizadas e na sua concordância. . . . . . . 76

Tabela 8. OR da associação entre o genótipo de p53 e qualquer infecção com HPV de alto risco oncogênico nas diferentes metodologias utilizadas e na sua concordância. . . . . . . 76

Tabela 9. OR das associações entre o genótipo de $p 53$ e infecções ${ }^{1}$ persistentes $^{2}$ para HPV de baixo risco oncogênico nas diferentes metodologias utilizadas e na sua concordância. . . . 77

Tabela 10. OR das associações entre o genótipo de $p 53$ e infecções ${ }^{1}$ persistentes $^{2}$ para HPV de alto risco oncogênico nas diferentes metodologias utilizadas e na sua concordância. . . . .78

Tabela 11. OR das associações entre o genótipo de $p 53$ e infecções ${ }^{1}$ persistentes ${ }^{2}$ para HPV16 nas diferentes metodologias utilizadas e na sua concordância. . . . . . . . . . . . 78

Tabela 12. OR das associações entre o genótipo de $p 53$ e infecções ${ }^{1}$ persistentes de curta duração $^{2}$ para HPV-16 e HPV-18 nas diferentes metodologias utilizadas e na sua

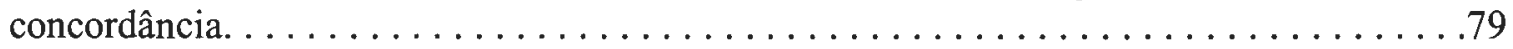

Tabela 13. OR das associações entre o genótipo de $p 53$ e infecções ${ }^{1}$ persistentes de curta duração $^{2}$ para HPV-16 e HPV-18 nas diferentes metodologias utilizadas e na sua

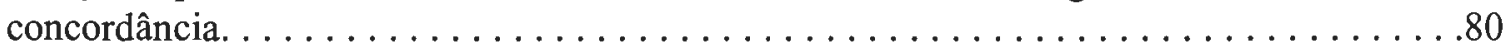

Tabela 14. OR das associações entre o genótipo de $p 53$ e LSIL $^{1}$ nas diferentes metodologias utilizadas e na sua concordância. . . . . . . . . . . . . . . . . . 81

Tabela 15. OR das associações entre o genótipo de $p 53$ e HSIL $^{1}$ nas diferentes metodologias utilizadas e na sua concordância. . . . . . . . . . . . . . . . . 


\section{LISTA DE ABREVIATURAS}

DHPLC: cromatografía líquida desnaturante de alta resolução

DNA: ácido desoxirribonucléico

dNTP: desoxirribonucleotídeos trifosfatados

HHV-6: Herpesvírus Humano tipo 6

HPV: Papilomavírus Humano

HSIL: lesão intraepitelial escamosa de alto grau

HSV-2: vírus Herpex simplex tipo 2

INCA: Instituto Nacional do Câncer

IARC: Agência Internacional de Pesquisa em Câncer

kb: kilobases

LCR: região regulatória

LSIL: lesão intraepitelial escamosa de baixo grau

MHC: Antígeno de Histocompatibilidade Principal

mRNA: ácido ribonucléico mensageiro

NIC: neoplasia intraepitelial cervical

OR: razão de chance.

ORF: fase aberta de leitura

pb: pares de bases

PCR: reação em cadeia da polimerase

RFLP: polimorfismo do comprimento dos fragmentos de restrição

SIL: lesão intraepitelial escamosa

SSCP: Single Strand Conformational Polymorphism

SV40: Vírus símio 40 


\section{RESUMO}

Nos últimos anos, inúmeros estudos epidemiológicos evidenciaram a forte associação entre o carcinoma do colo uterino e a infecção por papilomavírus humano (HPV). Esta associação deriva do reconhecimento de que estes vírus codificam oncoproteínas, dentre as quais E6 e E7, que apresentam propriedades transformantes. O produto do gene E7 se liga ao produto do gene retinoblastoma que perde a sua função de regular negativamente o ciclo celular. O produto do gene E6 se liga ao produto do gene supressor de tumor $p 53$ levando a sua degradação pela via de proteólise dependente de ubiquitina.

O gene $p 53$ é um supressor tumoral com função de regulação do ciclo celular que apresenta vários polimorfismos distintos em diversos grupos étnicos e tem sido amplamente estudado tanto em tecidos normais quanto em tecidos tumorais. $\mathrm{O}$ polimorfismo do códon 72 do gene $p 53$ é o mais estudado e pode apresentar três alelos diferentes na população. Um alelo codifica arginina (Arg), um codifica prolina (Pro) e outro, raramente encontrado, codifica cisteína (Cys).

Em 1993 foi iniciado um estudo epidemiológico da história natural da infecção por HPV e neoplasia da cérvice uterina em uma população feminina de baixa renda em São Paulo (Brasil), uma das áreas de maior risco em todo o mundo. O estudo focaliza a infecção persistente por tipos oncogênicos de HPV como evento precursor que leva à carcinogênese do colo do útero e visa entender os atributos da história natural da infecção viral e das doenças associadas ao colo uterino. Um dos objetivos deste estudo é avaliar se o polimorfismo do códon 72 do gene $p 53$ pode, ou não, ser utilizado como marcador de predisposição ao câncer do colo do útero uma vez que um estudo inicial relatou que pacientes portando o genótipo p53Arg homozigoto seriam 7 vezes mais susceptíveis ao desenvolvimento de neoplasia da cérvice uterina que pacientes contendo o genótipo p53Pro e heterozigoto p53Pro/Arg. Contudo, vários estudos posteriores contradizem e corroboram esses achados.

O presente projeto teve como objetivos, portanto, verificar se o polimorfismo do códon 72 do gene $p 53$ poderia estar associado a infecções persistentes por HPV e ao risco de neoplasia do colo do útero, além de comparar metodologias de deteç̧ão utilizadas por outros estudos, visando esclarecer se os motivos que levam à discordância dos resultados podem ser atribuídos a ocorrência de erros classificatórios metodológicos.

Ao todo, sete metodologias de detecção foram comparadas. Apenas uma delas, PCR alelo-específica, apresentou resultado discordante das demais utilizadas. Coincidentemente, essa metodologia foi amplamente utilizada por muitos estudos que encontraram associações tanto positivas quanto negativas. Isso poderia nos dar indícios de que os erros classificatórios dependentes de metodologia poderiam influenciar os resultados de correlação entre o polimorfismo do códon 72 e o risco de neoplasia do colo do útero. As correlações observadas por este trabalho entre este polimorfismo do códon 72 e o risco de neoplasia do colo uterino não mostraram associação deste polimorfísmo com o risco de infecções persistentes por HPV e as lesões precursoras do carcinoma do colo uterino. 


\begin{abstract}
In recent years, a number of epidemiological studies have pointed toward a strong association between cervical cancer and infection by Human Papillomavirus (HPV). This association derives from the discovery that these viruses code for oncoproteins, among them E6 and E7 that have transforming properties. The E7 gene product associates with the retinoblastoma gene product, causing the latter to lose its function as a negative regulator of the cell cycle. The E6 gene product interacts with the tumor suppressor p53 gene product, resulting in its degradation via ubiquitin dependent proteolysis.

The $p 53$ gene is a tumor suppressor that funcions in the regulation of the cell cycle. It presents a number of distinct polymorfisms in diverse ethnic groups, and has been widely studied, both in normal and tumor tissues. The polymorfism of codon 72 is the most studied, and may present three different alleles in the population. One alelle codes for arginine (Arg), another codes for proline (Pro), and a third, rarely found, codes for cystein (Cys).

In 1993 an epidemilogical study of the natural history of infection by HPV and its possible association with cervical neoplasia was initiated in a population of low income females in São Paulo, Brazil, one of the areas of greatest risk in the world. The study focuses on persistent infection by oncogenic types of HPV as a precursor to carcinogenesis of the cervix, and seeks to understand the attributes of the natural history of viral infection and of illnesses associated with the cervix. One of the objectives of the study is to evaluate if the polymorfisms of codon 72 of $p 53$ can or not be used as a marker of predisposition to cervical cancer, given the finding in the initial study that patients who were homozygous for the p53Arg genotype were 7 times more susceptible to developing cervical neoplasias than those patients who were homozygous for p53Pro, or heterozygous p53 Pro/Arg. Previous studies have been realized both supporting and disputing these findings.

The current study had two main objectives: to verify if the polymorfism of p53 codon 72 could be associated with persistent infections of HPV and the risk of cervical neoplasia, as well as to compare methods of detection used by other studies, in an attempt to clarify if the discording results of past studies could be due to methodological classification errors.

Seven detection methods were compared. Only one of these, allele specific PCR, presented discording results from the rest. Coincidentally, this method was widely used in a number of studies which found both positive and negative associations. This might indicate that the method-dependent classification errors could influence the results of correlation between codon 72 polymorphism and the risk of cervical neoplasia. The correlations observed by this study did not demonstrate an association between codon 72 polymorphism and the risk of persistent HPV infection and precursor lesions of cervical cancer.
\end{abstract}




\section{INTRODUÇÃO}

\section{O CARCINOMA DO COLO UTERINO}

\subsection{Epidemiologia}

O carcinoma do colo uterino ocupa o quinto lugar dentre as estimativas de incidência dos principais tipos de câncer que acometem a população mundial - logo após as neoplasias de pulmão, estômago, mama e cólon - segundo análises do IARC (International Agency for Research on Cancer) (IARC, 1995). Entretanto, apresenta-se como a segunda neoplasia feminina mais importante, depois do carcinoma de mama, e é responsável por cerca de 440.000 novos casos e por cerca de 200.000 mortes a cada ano, (BOSCH et al., 1997).

A incidências acima de 30 casos deste tipo de neoplasia por 100.000 mulheres são comumente observadas em países em desenvolvimento do Sudeste Asiático, África e América do Sul (IARC, 2001). A associação de alta incidência de carcinoma do colo uterino em regiões menos desenvolvidas parece estar ligada a uma combinação de fatores como desnutrição, falta de prevenção para as lesões precursoras, alto índice de paridade e higiene (FRANCO et al., 1997).

Dentre as neoplasias que afetam a população feminina no Brasil, o carcinoma do colo uterino ocupa o segundo lugar em incidência e mortalidade com taxas brutas de 18,9 e 4,3 casos por 100.000 mulheres, respectivamente (INCA, 2000). Para 2002, as estimativas sobre incidência e mortalidade por este tipo de câncer prevêem 4.005 novos óbitos. 


\subsection{Histopatologia}

O carcinoma do colo uterino parece ser conseqüência da evolução contínua de lesões precursoras não-invasivas, caracterizadas por atipias celulares denominadas displasias. Estas displasias eram comumente divididas em leve, moderada e severa dependendo do grau de diferenciação do epitélio. Entretanto, a prática demonstrou que não era possível distinguir eficientemente os epitélios portadores de displasia severa daqueles portadores de carcinoma in situ, e que as displasias moderadas e severas tendiam a convergir imperceptivelmente para lesões de alto grau (RICHART, 1973). Essas observações levaram a introdução do termo "neoplasia intraepitelial cervical" (NIC) para designar o espectro de doenças do colo uterino presentes na carcinogênese deste epitélio. Esta terminologia sugeria a existência de uma continuidade nas alterações citológicas que se iniciava na displasia leve (NIC I), transitava progressivamente através dos estágios intermediários de doenças intraepiteliais (NIC II E III) e terminava no carcinoma invasivo (RICHART, 1973). Após o acúmulo de dados moleculares, entretanto, tornou-se aparente que o espectro de alterações histológicas atípicas do colo do útero relacionadas ao HPV poderia ser melhor segmentado em dois grupos do que em três e a classificação de NIC foi modificada. As lesões referidas como displasias leves, condilomas planos ou NIC I passaram a ser designadas como NIC de baixo grau. As lesões supostamente consideradas como precursoras potenciais do carcinoma invasivo, exigindo tratamento, que continham atipias citológicas mais severas, passaram a ser designadas como NIC de alto grau (RICHART, 1990).

Os diversos estágios de evolução citológica, por sua vez, são observados no momento da coleta de células endo e ectocervicais uterinas em esfregaços e consistem 
em cinco classes (I, II, III, IV e V) que variam conforme o grau de indiferenciação celular observado nas células exfoliadas (PAPANICOLAOU e TRAUT, 1943). Em 1989, houve a criação de um outro sistema classificatório, denominado sistema de Bethesda, que introduziu o termo lesão intraepitelial escamosa ou SIL (squamous intraepithelial lesion), renomeou a classe III da terminologia de Papanicolaou como SIL de baixo grau (LSIL ou low grade squamous intraepitelial lesion) correspondendo as alterações citológicas atípicas encontradas nas classificações histológicas NIC I ou NIC de baixo grau e agrupou as classes IV e V desta mesma terminologia como SIL de alto grau (HSIL ou high grade squamous intraepithelial lesion) correspondendo às alterações citológicas atípicas encontradas nas classificações histológicas NIC II e III ou NIC de alto grau (HERBST, 1992).

\subsection{Fatores de Risco}

Estudos epidemiológicos iniciais indicaram claramente que o desenvolvimento do carcinoma do colo uterino era fortemente influenciado pelas medidas de atividade sexual, seja das próprias mulheres ou de seus parceiros (VILLA, 1997). O fato de que os principais fatores de risco predisponentes a essa neoplasia definidos até o momento, tais com idade precoce do primeiro coito, a elevada paridade da paciente e o elevado número de parceiros sexuais durante toda a vida da paciente (MUÑOZ e $\mathrm{BOSCH}, 1996)$, estarem tão associados ao comportamento sexual dos indivíduos afetados, permitiu que se concluísse que o comportamento epidemiológico do carcinoma cervical assemelhava-se ao de uma doença sexualmente transmissível (ZUR HAUSEN, 1996). 
Partiu-se, então, para a tentativa de isolar um agente infeccioso sexualmente transmissível que fosse o responsável pelo posterior desenvolvimento do carcinoma cervical (STERN, 1996). No final da década de 60, foi relatada a existência de um padrão soroepidemiológico sugestivo do papel do vírus herpex simplex tipo 2 (HSV-2) na etiologia desta doença. Entretanto, as evidências laboratoriais existentes não foram suficientes para comprovar a participação do HSV-2 na etiologia do carcinoma cervical (KRCMÁR et al., 1986; VILLA, 1997).

A associação causal de papilomavírus com verrugas benignas, ou papilomas, em alguns animais, tais como bovinos e coelhos, por outro lado, já era conhecida há algum tempo (MAGALHÃES, 1920; SHOPE, 1933). Assim, na década de 70, zur Hausen apontou a similaridade dos padrões epidemiológicos das verrugas genitais e do carcinoma do colo uterino, sugerindo um envolvimento dos agentes causadores destas verrugas no desenvolvimento deste tipo de neoplasia (ZUR HAUSEN, 1977). Mesmo assim, os diversos estudos epidemiológicos que estabeleceram a importância do papel das infeç̧ões pelo HPV na neoplasia do colo uterino dependeram, ainda, da disponibilidade de métodos moleculares para a detecção do DNA do HPV (STERN, 1996) e do acúmulo suficiente de dados experimentais para indicar que o papilomavírus humano (HPV) são os verdadeiros agentes etiológicos do carcinoma cervical (BOSCH et al., 2002; WALBOOMERS et al., 1999).

Outros fatores de risco, tais como o tabagismo, uso de contraceptivos orais a longo termo e alto número de gestações, embora tenham sido fracamente associados em diversos estudos publicados (MUÑOZ e BOSCH, 1996; VILLA e FRANCO, 1989), tiveram seus papéis como co-fatores da carcinogênese induzida pelo HPV comprovados 
em estudos mais recentes (MORENO et al., 2002; MUNÕZ et al., 2002; ROUSSEAU et al., 2000; YLITALO et al., 1999).

\section{PAPILOMAVÍRUS HUMANO}

\subsection{Genótipos e Classes}

Até o momento foram descritos mais de 100 tipos de papilomavírus humanos (MÜNGER et al., 2001), muitos dos quais envolvidos em processos de natureza neoplásica, especialmente o carcinoma do colo uterino.

Os papilomavírus humanos (HPV) são epiteliotrópicos, possuindo especificidade por diferentes sítios anatômicos. Os HPV são divididos em três grandes classes: 1) tipos de mucosa e genitais, 2) tipos não genitais e 3) tipos específicos da epidermodisplasia verruciforme, que é uma doença de pele rara, caracterizada por lesões cutâneas verrucosas disseminadas. Os tipos não genitais infectam a pele e causam a verruga comum e plantar, lesões com baixíssima probabilidade de malignização. Os tipos genitais são principalmente encontrados na genitália interna e externa, mas também podem causar lesões na cavidade oral, faringe e laringe.

\subsection{Associação com Carcinoma do Colo Uterino}

Os tipos de HPV que infectam o trato anogenital podem ser classificados segundo o risco de estarem associados ao desenvolvimento de lesões neoplásicas do colo uterino (ZUR HAUSEN, 1996): 
- Tipos de baixo risco oncogênico - (HPV-6, 11, 42, 43 e 44 ente outros) associado à lesões benignas do colo uterino e à verrugas genitais.

- Tipos de alto risco oncogênico - (HPV-16, 18, 31, 33, 35, 45 e 58 entre outros) associados à lesões intraepiteliais de alto grau, especialmente carcinomas invasivos do colo uterino.

Estudos caso-controle contribuíram para o esclarecimento da associação epidemiológica entre a infecção por HPV e o câncer cervical. Mulheres com infecção por HPV de alto risco têm risco relativo em média 50 vezes maior de desenvolver câncer cervical, quando comparadas às mulheres não portadoras deste tipo de infecção (ROZENDAAL et al., 1996). Apesar da maior parte das infecções por HPV ser transiente, há um pequeno número de mulheres com infecção persistente pelo vírus, nas quais a presença de um mesmo tipo de HPV é detectada mais de uma vez, durante determinado período de tempo. Estas mulheres têm risco maior de desenvolver neoplasias cervicais, quando comparadas a mulheres que eliminam a infeç̧ão pelo HPV (EVANDER et al., 1995; FRANCO et al., 1997; HILDESHEIM et al., 1994; HO et al., 1995; KOUTSKY et al., 1992; SCHLECHT et al., 2001). Desta forma, a infecção persistente é um dos passos cruciais para o desenvolvimento das lesões cervicais. Estudos relatam maior persistência viral em mulheres acima de 30 anos e com infecções por HPV de alto risco oncogênico (HILDESHEIM et al., 1994) ou com a presença de alta carga viral nas lesões (CABALLERO et al., 1998; CUZICK et al., 1995). 
Geralmente, ocorre um intervalo de tempo relativamente longo entre a infecção primária por tipos de HPV de alto risco oncogênico e o desenvolvimento de neoplasias intraepiteliais cervicais, carcinoma in situ e câncer invasivo (NOBBENHUIS et al., 1999). Neoplasias intraepiteliais cervicais têm um pico de incidência entre 25 e 30 anos de idade, enquanto que a incidência de câncer cervical está entre 45 e 55 anos, podendo ser mais precoce em certas populações incluindo o Brasil (IARC Working Group, 1995). Esta observação sugere que o período de latência é de muitos anos entre a infecção inicial e o desenvolvimento da neoplasia intraepitelial e que a progressão para câncer invasivo requer entre 20 e 30 anos (ZUR HAUSEN, 1996).

A caracterização de fatores associados à persistência do vírus, poderia estar identificando mulheres que estão sob maior risco de virem a desenvolver uma neoplasia cervical maligna. Vários estudos vêm sendo realizados com o objetivo de identificar determinantes potenciais da deteç̧ão persistente de HPV nas células cervicais (FRANCO et al., 1999; HILDESHEIM et al., 1994; HO et al., 1995).

Entre 50 e $60 \%$ dos tumores apresentam HPV-16, enquanto que a detecção de HPV-18 varia de 10 a 20\% nas amostras de câncer cervical. Sabe-se ainda, que na ausência de lesões citológicas (SIL), tipos de HPV de alto risco oncogênico, em particular HPV-16, tendem a persistir mais do que os tipos de baixo risco oncogênico (BOSCH et al., 1995; FRANCO et al., 1997). 


\subsection{Infeç̧ão}

A infecção pelo HPV é necessária, porém não sufíciente para o desenvolvimento do carcinoma do colo uterino, desta forma, apenas uma pequena fração das mulheres infectadas com HPV de alto risco desenvolve lesões neoplásicas do colo uterino. Mulheres que apresentam infecção persistente com HPV de alto risco, além de uma carga viral alta, estão sob um risco maior de desenvolverem neoplasia de cérvice uterina (VILLA, 1997).

A infecção anogenital por HPV é preferencialmente transmitida pelo contato sexual, e a incidência é mais elevada em mulheres jovens, na faixa etária entre 22 e 25 anos (SCHIFFMAN, 1992). A infecção genital por HPV de alto risco confere um risco relativo em torno de 50 para o desenvolvimento de câncer cervical (SCHIFFMAN, et al., 1993).

Os HPV infectam as células basais do epitélio e seu acesso se dá através de microlesões pré-existentes. As infecções permissivas constituem o ciclo produtivo clássico como o de outros vírus de DNA: após a adsorção e penetração, com a diferenciação das células do epitélio, o vírus utiliza fatores da maquinaria celular para sua transcrição, tradução e replicação, dando origem a novos vírus nas camadas mais diferenciadas. O genoma viral é mantido no estado epissomal no núcleo das células normais infectadas, entretanto, está integrado no genoma celular na maioria das células tumorais (VILLA, 1997). 


\subsection{Historia Natural}

A história natural das infecções por HPV não é bem compreendida até o presente. Aparentemente, a maioria dessas infecções não leva ao desenvolvimento de sintomas incômodos ou lesões macroscopicamente visíveis. Se há o estabelecimento efetivo de quaisquer sinais clínicos, entretanto, estes tendem a desaparecer dentro de poucos anos, concomitantemente a outros sinais microscópicos e moleculares da infecção (IARC, Working Group, 1995).

A existência de fatores inerentes a alguns indivíduos infectados pelo HPV, tais como a demora na criação de respostas imunológicas efetivas ou a geração de padrões menos efícientes de respostas imunológicas celulares ou a presença de co-fatores (tabagismo, uso constante de anticoncepcionais, etc.), por outro lado, parece permitir a replicação do vírus em larga escala e aumentar a probabilidade de desenvolvimento de lesões novas ou recorrentes. Apesar disso, somente uma pequena porcentagem de indivíduos afetados por tipos oncogênicos de HPV efetivamente desenvolvem o carcinoma do colo do útero (IARC, Working Group, 1995).

Uma grande variedade de fatores, tanto exógenos quanto inerentes aos vírus e hospedeiros, que podem influenciar o curso de uma infecção pelo HPV. Os tipos de variantes do vírus, o sítio anatômico da infecção, e a resposta imunológica do hospedeiro definem se uma dada infecção genital pelo HPV será autolimitada e escapará da detecção, produzirá uma lesão proliferativa benigna clinicamente evidente, ou lentamente, durante o curso de vários anos, induzirá a transformação maligna das células infectadas (IARC, Working Group, 1995). 


\subsection{Biologia}

Os HPV constituem um grupo de vírus hospedeiro-específicos, pertencentes a família Papillomaviridae, gênero Papillomavirus (VAN REGENMORTEL et al., 1999). Estes vírus têm diâmetro entre 55 e 60nm, apresentado sob a forma de partículas icosaédricas, não envelopadas, de simetria pentagonal, constituídas por 72 unidades denominadas capsômeros (ZHOU e FRAZER, 1996).

Os diferentes tipos de HPV possuem uma organização genômica geral bem conservada. O genoma destes vírus, de aproximadamente 8.000 nucleotídeos, pode ser dividido em três regiões funcionalmente diferentes: uma região controladora denominada LCR (Long Control Region), uma região precoce ou região E (Early) e uma região tardia ou L (Late) (Figura 1).

A LCR encontra-se entre L1 e E6, em uma região de 500 a 1.000 pares de bases, onde não existe uma ORF de tamanho detectável (CHAN et al., 1989). Essa região contém a origem de replicação de DNA, vários promotores para a síntese de mRNA e seqüências reguladoras da transcrição (BROKER, 1987; BROWN e FIFE, 1990). O produto de transcrição viral é um mRNA policistrônico que pode ou não ser processado e ter, como resultado final do processo traducional, mais de uma proteína a partir de uma mesma seqüência codificadora (ARENDS et al., 1990).

Os genes da região L (L1 e L2) codificam para proteínas estruturais do capsídeo, enquanto que os genes $\mathrm{E}(\mathrm{E} 1, \mathrm{E} 2, \mathrm{E} 4, \mathrm{E} 5, \mathrm{E} 6$ e E7) codificam para proteínas com diversas funções reguladoras envolvidas na persistência genômica, replicação do DNA viral, transcrição de genes virais e proliferação celular (McMURRAY et al., 2001; HOWLEY, 1996). 


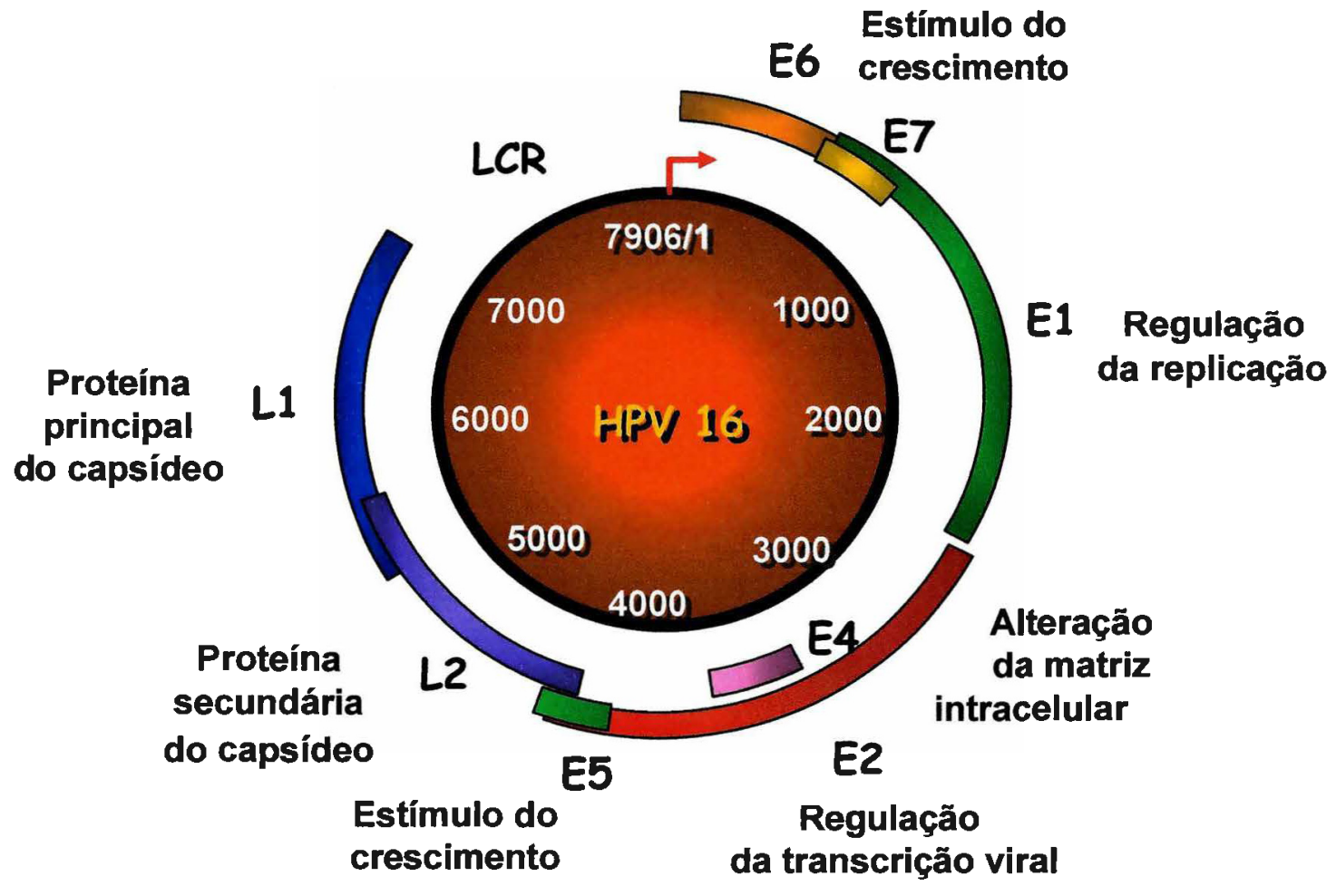

Figura 1. Mapa físico do genoma do HPV-16, com a região precoce (E), a região tardia (L) e a LCR que corresponde a região regulatória (VILLA, 1997). 
A infecção produtiva por estes vírus está relacionada ao grau de diferenciação da célula epitelial. Para gerar uma lesão produtiva, estes vírus precisam infectar as células basais dos epitélios escamosos, uma vez que estas são as únicas capazes de se dividir. É nestas células e nas células parabasais que ocorre a replicação do DNA viral e a expressão dos genes precoces que estimulam a progressão da fase G1 à fase S. Ao mesmo tempo, o vírus necessita de um certo grau de diferenciação do tecido para que ocorra a expressão de fatores próprios de células diferenciadas necessários a expressão dos genes virais tardios (McMURRAY et al., 2001) (Figura 2).

\subsection{Proteínas Virais}

A proteína L1 é a principal constituinte do capsídio do papilomavírus e a proteína viral mais abundante, constituindo cerca de $80 \%$ do total das proteínas virais (HOWLEY, 1996). Essa proteína parece abrigar epítopos tipo-específicos e ser altamente imunogênicas (revisado ZUR HAUSEN, 1996). A proteína L2, por sua vez, é considerada a proteína viral menos abundante e, embora seja um componente estrutural adicional do capsídio viral, associada a L1, parece ter um papel importante na incorporação do DNA viral dentro do vírion, através da adição gradual de proteínas do capsídio ao redor do genoma do papilomavírus (ZHOU e FRAZER, 1996). 


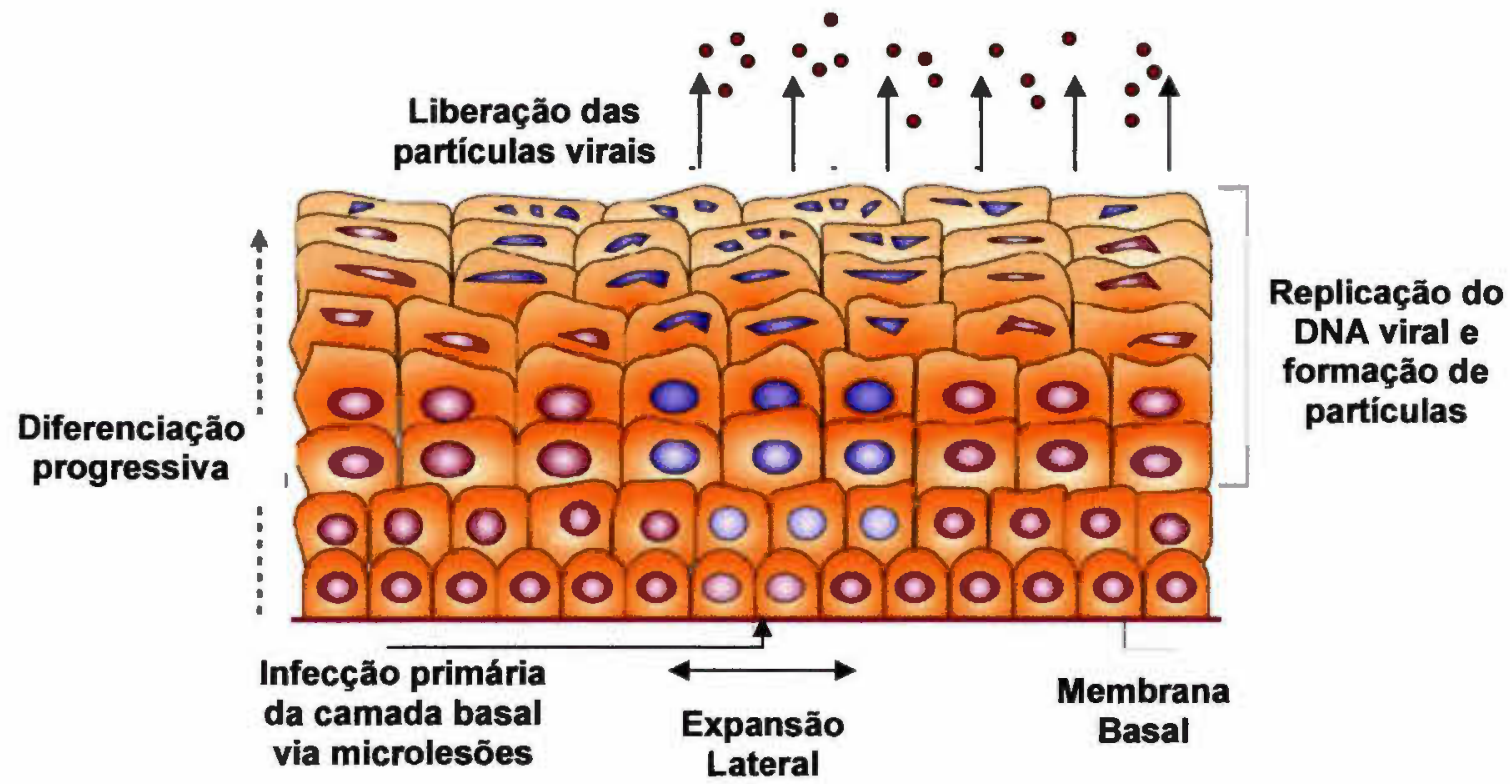

Figura 2. O ciclo de vida do papilomavírus humano. Para que a infecção seja produtiva, o vírus precisa infectar a camada basal. Isso normalmente ocorre através de microlesões, na pele ou na mucosa. As células infectadas se dividem e se espalham lateralmente. Algumas dessas células progenitoras migram para as camadas diferenciadas suprabasais, onde genes virais serão ativados, o DNA do vírus será replicado e as proteínas do capsômero serão formadas. As partículas virais surgem e são liberadas na superfície da mucosa onde podem infectar tecidos adicionais (Modificado de ZUR HAUSEN, 2002). 
A proteína E1 é uma helicase que forma um complexo com E2, uma proteína reguladora da transcrição viral. Elas afetam diferentemente a expressão gênica viral e representam os principais reguladores intragenômicos através da formação de dímeros em sítios específicos de ligação presentes na LCR (THIERRY e YANIV, 1987). O rompimento e/ou deleção do gene E2, devido à integração do genoma viral no celular, são eventos freqüentemente observados em biópsias de tecidos tumorais e linhagens celulares derivadas de neoplasias malignas do colo uterino (SCHWARZ et al., 1985). Além disso, mutações nos genes E1 e E2 aumentam a capacidade do HPV-16 imortalizar células in vitro (ROMANCZUK e HOWLEY, 1992; VERNON et al., 1997). Estes eventos levaram a supor que alterações no gene E2 facilitariam a transformação de células humanas e a progressão para um fenótipo maligno (ZUR HAUSEN, 1996).

A proteína E4 parece estar envolvida na maturação e na liberação das partículas virais para o meio extracelular (ZUR HAUSEN, 1996), apesar deste papel ainda não ser bem elucidado. Já proteína E5 é sabidamente a principal proteína transformante de papilomavírus humano bovinos (SCHILLER et al., 1986), por outro lado, nas células infectadas por HPV, esta proteína não apresenta o mesmo efeito (PIM e COLLINS, 1992). Em lesões precursoras de baixo grau, encontram-se altos níveis desta proteína, sugerindo alguma função (ainda não estabelecida) nos estágios precoces da infecção por HPV. Contrariamente, o gene E5 está freqüentemente deletado em células de carcinomas cervicais, indicando a ausência de um papel essencial para a manutenção do fenótipo maligno nestas células (ZUR HAUSEN, 2000).

O produto do gene E6 consiste de uma proteína nuclear de cerca de 150 aminoácidos, que se liga ao produto do gene p53, levando a sua degradação pela via de 
proteólise dependente de ubiquitina (SCHEFFNER et al., 1990 e 1993). Esta interação foi a primeira a ser descrita e é a mais conhecida dentre as diversas e não tão bem elucidadas interações da proteína E6 (ZUR HAUSEN et al., 2000). A proteína p53 (como será descrito adiante) é uma fosfoproteína nuclear de $53 \mathrm{kDa}$, cuja função primordial é a manutenção da integridade genômica através da regulação do ciclo celular (MANTOVANI et al., 2001). Além disso, foi demonstrado que E6 de HPV-16 ativa telomerase em queratinócitos e células epiteliais mamárias em estágios precoces da infecção por HPV (KLINGELHUTZ et al., 1996) e inibe a degradação da família de quinases SRC. Outras interações de E6 de HPV de alto risco e seu efeito na estabilidade celular podem ser observadas na figura 3.

O produto do gene E7 de HPV é uma fosfoproteína cuja principal e mais estudada interação é com a forma hipofosforilada do gene de susceptibilidade ao retinoblastoma, pRB. A ligação da proteína E7 pRB libera o fator de transcrição celular E2F dos complexos com E2F/pRB, que é responsável pela ativação da transcrição de genes regulatórios necessários para a proliferação celular, além de genes necessários para a síntese do DNA (MUNGER, et al., 2001; VILLA, 1997). A expressão de E7 também promove o acúmulo de diversas outras proteínas celulares tais como p16INK4a, cuja expressão é reprimida por $\mathrm{pRB}$. A inativação de $\mathrm{pRB}$ mediada por $\mathrm{E} 7$ faz com que a expressão de p16INK4a seja acentuada. Devido a este fato, o acúmulo de p16INK4a tem sido proposto como um biomarcador para identificação de displasias em biópsias de epitélio do colo uterino (KLAES, et al., 2001).

A proteína E7 dos HPV de alto risco também possui a capacidade de interagir com diversas outras proteínas celulares. As diversas funções de E7 e suas 
interações com diversos passos envolvidos na imortalização celular estão resumidos na figura 3.

\subsection{Potencial Oncogênico}

A síntese contínua das proteínas precoces E6 e E7 do HPV parece ser uma etapa essencial para o desenvolvimento de tumores malignos, visto que ocorre sempre durante a gênese dos tumores anogenitais associados a este vírus (ZUR HAUSEN, 1996). A continuidade da síntese destas oncoproteínas advém do evento de integração do genoma viral ao genoma da célula hospedeira, que ocorre durante a progressão de uma lesão pré-maligna para um carcinoma in situ. Esse evento não ocorre em lugares específicos dos cromossomos celulares, mas sempre interrompe o segmento genômico viral correspondente aos genes precoces E2 e E1, resultando na perda de função do gene E2 (SCHWARZ et al., 1985). Os produtos desse gene são os responsáveis pelo controle da transcrição viral, em especial pela repressão da transcrição do promotor principal, localizado no início da região precoce e responsável pelo controle transcricional dos genes E6 e E7. Assim, deprende-se que, ao ocorrer a integração, passa-se a sintetizar as proteínas precoces, como E6 e E7, de forma descontrolada (ROMANCZUK e HOWLEY, 1992). Além disso, esse evento confere também um aumento da estabilização dos transcritos virais, através da formação de moléculas do mRNA de E6/E7 flanqueadas por seqüências celulares que inativam um elemento desestabilizador localizado na região 3' do mRNA viral (SCHWARZ et al., 1985). 


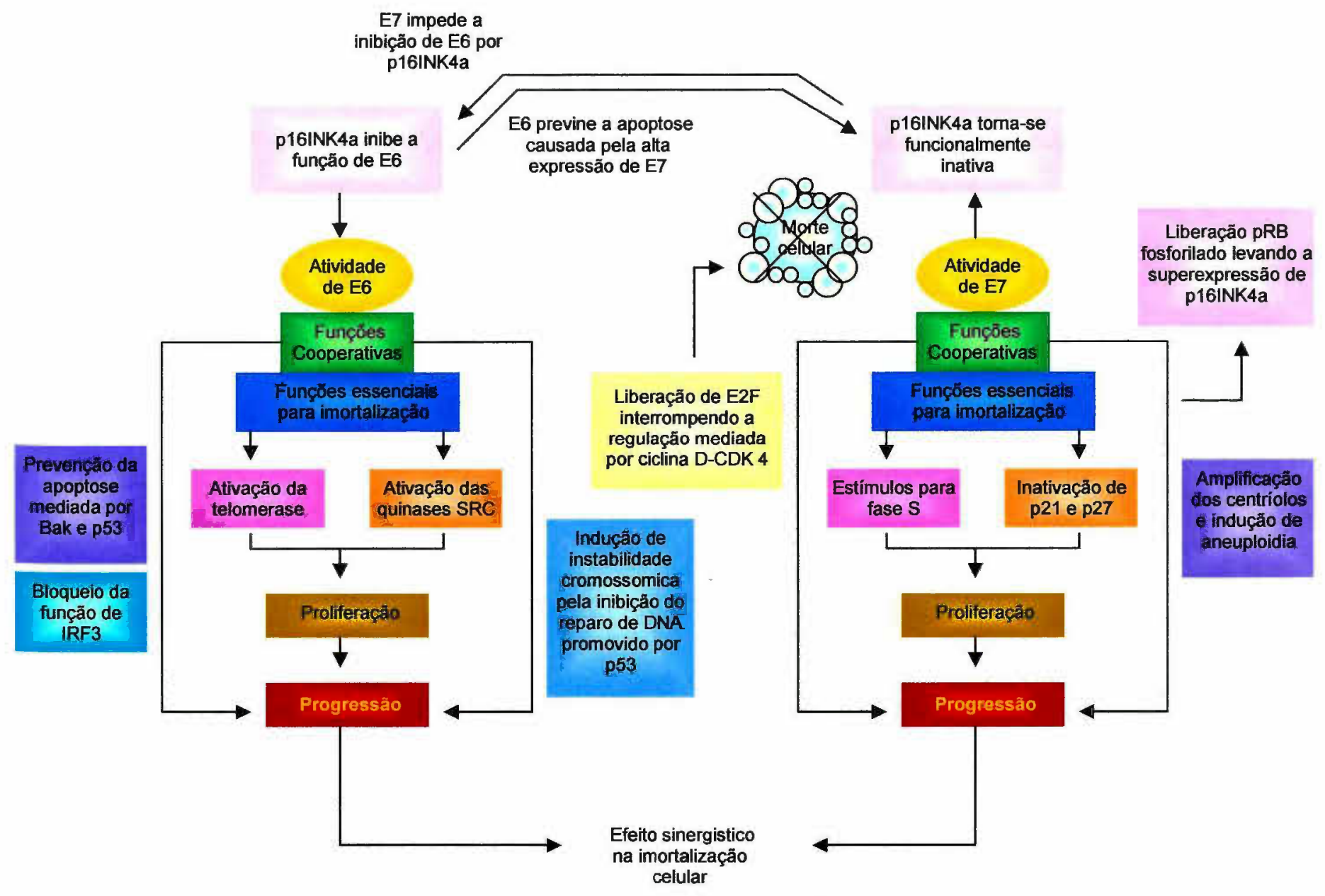

Figura 3. Funções das oncoproteínas E6 e E7 e suas interações com diversos passos envolvidos na imortalização celular. E6 promove a ativação da telomerase e das quinases SRC e a inibição de p53 e Bak. E7 inibe pRB e promove a liberação de E2F resultando na superexpressão de p16INK4a. Esta proteína, por sua vez, também é inativada por E7. E7 também estimula a entrada na fase $S$ e inativa p21 e p27. E6 e E7 cooperam para a imortalização celular e a transformação maligna. E6 previne a apoptose induzida por altos níveis de E2F e E7 impede a inibição de E6 por p16INK4a (Modificado de ZUR HAUSEN, 2002). 
Há mais de uma década, tem sido verificada a interação de células epiteliais com genes virais capazes de alterar o processo de diferenciação normal destas ocasionando a imortalização celular (DÜRST et al., 1987; PIRISI et al., 1987 e 1988; SCHLEGEL et al., 1988). Diferentes sistemas têm mostrado que as funções das proteínas transformantes codificadas pelos HPV associados ao câncer anogenital em humanos, podem ser reproduzidas in vitro (BEDELL et al., 1989; KANDA et al., 1988; MATLASHEWSKI et al., 1987; PIRISI et al., 1987). Dentre esses estudos, os dados iniciais de maior importância, foram a constatação de que os HPV-16, 18 e 31, os mais correlacionados à lesões do trato anogenital e com potencial para progressão maligna, podem imortalizar culturas primárias de queratinócitos normais de prepúcio ou células epiteliais da região cervical humana (o mesmo não acontecendo com HPV de baixo risco) (KAUR e McDOUGALL, 1988; SCHLEGEL et al., 1988; WOODWORTH et al., 1990).

No processo de imortalização de queratinócitos humanos normais, os HPV de alto risco promovem alterações de proliferação e de diferenciação celular. Estas células tornam-se altamente proliferantes mesmo na presença de fatores indutores de diferenciação celular, como fatores protéicos presentes no soro e altas concentrações de cálcio, e continuam dividindo indefinidamente in vitro, não se diferenciando (SCHLEGEL et al., 1988). No entanto, é importante salientar que estas células não são transformadas, pois não são capazes de gerar tumores quando inoculadas em animais atímicos. Eventos adicionais, como por exemplo a ativação de oncogenes, são necessários para que a transformação celular direcionada à progressão maligna ocorra (PIRISI et al., 1988; STOREY et al., 1988). Os genomas de HPV presentes em carcinomas do colo uterino e em linhagens derivadas estão transcricionalmente ativos, e 
apresentam expressão regular e contínua dos genes E6 e E7 (SCHNEIDER-GADICKE e SCHWARZ, 1986; SMOTKIN e WETTSTEIN, 1986).

A atividade biológica das oncoproteínas E6 e E7 é dependente do tipo de células onde são expressas. A proteína E6 ou E7 de HPV 16 ou 18 é suficiente para transformar fibroblastos imortalizados de roedores (BEDELL et al., 1989; VOUSDEN et al., 1988). A expressão concomitante de E6 e E7 leva à imortalização de células mamárias epiteliais humanas (McDOUGALL, 1994). Contrariamente, diversos estudos mostram que a expressão de E6 e/ou E7, é ineficiente para imortalização de queratinócitos humanos normais e para a transformação de queratinócitos humanos imortalizados. No entanto, vale ressaltar, que a expressão destas proteínas, principalmente sua cooperação, é fundamental para a progressão e manutenção do fenótipo imortalizado ou maligno, visto que a inibição da expressão in vitro destas proteínas, interrompe a proliferação celular e em alguns casos pode ocorrer a reversão do fenótipo maligno ou imortalizado (BARBOSA et al., 1989; ZUR HAUSEN, 2000). Mais recentemente, JIANG e MILNER (2002) evidenciaram que a inibição do mRNA de E6, utilizando RNA de interferência (RNAi), promovia uma redução do crescimento celular e que, a inibição de mRNA de E7 levava as células tratadas à apoptose. 


\subsection{Fatores que afetam a progressão maligna}

O fato de uma pequena porcentagem das mulheres infectadas por HPV de alto risco desenvolverem carcinoma do colo uterino sugere que um período de latência de muitos anos entre a infecção inicial e o desenvolvimento deste tipo de neoplasia é necessário (ZUR HAUSEN, 2002). A grande maioria das mulheres infectadas elimina a infecção por mecanismos controlados pelo sistema imune. A imunossupressão permanente representa um importante fator de risco para a persistência do DNA viral e para a progressão de lesões (PETRY, et al., 1994), mas os fatores que determinam a persistência viral em outras mulheres não são completamente definidos. A expressão de oncogenes virais poderia promover alterações em genes envolvidos na apresentação de antígenos, ou de cascatas de sinalização que estariam envolvidas na supressão da transcrição de oncogenes virais (ZUR HAUSEN, 2000). A persistência do DNA viral pode ainda ser influenciada por outros fatores. Estes poderiam estar relacionados à natureza viral, como por exemplo, o tipo de HPV, a variação intratípica e a carga viral; e a outros fatores não relacionados ao vírus tais como o grande número de parceiros sexuais, exposição a agentes mutagênicos, fumo, infecções concomitantes, o uso de hormônios, imunossupressão e predisposição genética (Figura 4).

MAGNUSSON e colaboradores (1999), utilizando dados do Registro de Câncer Sueco - Swedish Cancer Registry, observaram que filhas adotadas apresentavam um risco $50 \%$ menor de desenvolvimento de carcinoma do colo uterino quando comparadas com filhas não adotadas. Estes dados evidenciam a influência da predisposição genética no desenvolvimento deste tipo de neoplasia. 

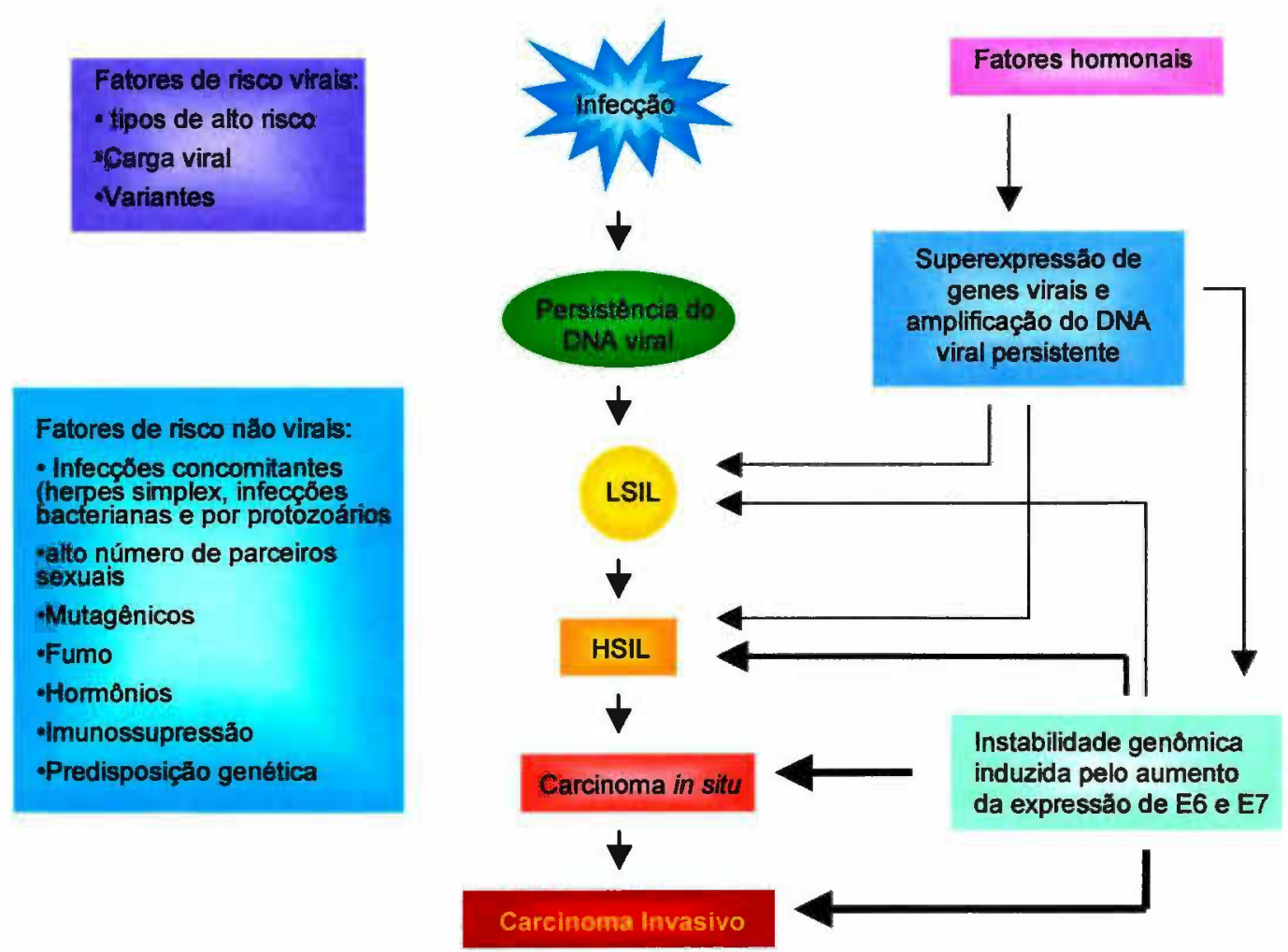

Figura 4. Fatores relacionados e não relacionados ao HPV que podem induzir a progressão maligna. Fatores de risco virais e não virais estão listados do lado esquerdo da figura. Fatores hormonais ativam os promotores virais e facilitam a imortalização de células infectadas pelo HPV. Agentes mutagênicos influenciam a persistência do DNA do vírus. Estes acentuam a progressão pela modificação celular das cascatas de sinalização que controlam a persistência do HPV, ou levam a um aumento na expressão de oncogenes virais por um efeito dose-resposta destes. Os crescentes níveis de expressão de E6 e E7, por sua vez, resultam num aumento da instabilidade genômica, que promove a progressão das células infectadas a um crescimento invasivo (modificado de ZUR HAUSEN, 2002). 


\subsection{Fatores Coadjuvantes a Oncogenicidade do HPV}

Alterações cromossômicas são freqüentemente encontradas nos tumores do colo uterino. Carcinomas distintos poderiam adquirir características mais agressivas associadas à instabilidade genômica. Os cromossomos mais alterados são o 11 e 17, além de regiões instáveis em microssatélites do cromossomo seis (KIRCHHOFF et al., 1999).

Fatores imunogenéticos controlados pela resposta imune parecem ter um papel relevante na progressão ou regressão de lesões causadas pelo HPV. Várias associações já foram descritas relacionando moléculas de MHC (complexo de histocompatibilidade principal) de classe I e II, com a susceptibilidade ou proteção a diversas doenças. Associações entre alelos ou haplótipos de genes do sistema MHC e o carcinoma do colo uterino ou com suas lesões precursoras, vem sendo descritas, mostrando que existe uma susceptibilidade genética à infecção pelo HPV, e que esta, em

parte, é conferida por genes deste sistema (APPLE et al., 1994; MACIAG e VILLA, 2000).

Alguns estudos relatam algumas associações entre o HPV e outros microorganismos. Uma das associações especuladas é com o herpesvírus humano 6 (HHV6). Este vírus é capaz de infectar células do colo uterino in vitro e ativar a transcrição dos genes E6 e E7 de HPV de alto risco (CHEN et al., 1994). Além disso, a inflamação crônica provocada pela infecção por Chlamydia tracomatis tem sido evidenciada como possível co-fator na carcinogênese mediada pelo HPV (SMITH et al., 2002). 


\section{A INTERAÇÃO ENTRE p53 E E6}

O gene supressor de tumor p53 é uma das principais defesas celulares contra a replicação viral e conseqüentemente da transformação celular. A proteína E6 dos HPV de alto risco promove a inibição deste efeito de $p 53$ por se ligar a sua proteína e induzir sua degradação pela via de proteólise dependente de ubiquitina. A degradação de p53 por E6 é um dos principais mecanismos promotores de instabilidade genômica, uma vez que este gene está envolvido, não somente, no reparo de danos no DNA, mas também na promoção da apoptose (MANTOVANI e BANKS, 1999).

\subsection{A Degradação de p53 Mediada por E6}

WERNESS e colaboradores (1990) mostraram que a proteína E6 de HPV16 e HPV-18 é capaz de se ligar à p53. Posteriormente foi revelada que essa interação promovia a degradação de p53 via proteólise dependente de ubiquitina (SCHEFFNER et al., 1990). Trabalhos subseqüentes demonstraram que a degradação de p53 mediada por E6 é dependente de uma proteína celular E6 associada (E6-AP), também conhecidas como UBE3A, (HUIBREGTSE et al., 1991; SCHEFFNER et al., 1993). Essa proteína é um peptídeo monomérico de $100 \mathrm{kDa}$ que atua como uma ligase proteína-ubiquitina E3. $\mathrm{Na}$ cascata de ubiquitinização, a proteína E1 celular ativa a ubiquitina que é então transferida por E2 celular conjugando enzimas para a ligase proteína ubiquitina E3 celular a qual reconhece proteínas alvo específicas (HERSHKO e CIECHANOVER, 1992). Interessantemente, mutantes de E6-AP que não se ligam a E6 também são incapazes de interagir com p53 (HUIBREGTSE et al., 1993), e proteínas p53 mutantes 
que não se ligam a E6 também não são susceptíveis a degradação induzida por E6-AP (SCHEFFNER et al., 1992), indicando que E6 é requerida para mediar a interação p53/E6-AP. Estudos mais recentes usando inibição antisense de E6-AP têm mostrado que níveis de p53 aumentam apenas em células expressando E6 (BEER-ROMERO et al., 1997), sugerindo que E6-AP não está envolvida normalmente na degradação de p53; em adição, o uso de um sistema de expressão da fissão de leveduras tem mostrado um requerimento absoluto tanto de E6 quanto de E6-AP para obter a degradação de p53 (WADDELL e JENKINS, 1998). Assim, a ligase E3 na cascata da degradação de p53 não é simplesmente E6-AP, mas deve ser um complexo formado por E6/E6-AP. Contudo, E6-AP não requer a proteína E6 selvagem para funcionar como uma ligase proteína-ubiquitina, já que foi demonstrado que E6-AP sozinha é capaz de se ligar a ubiquitina e muitas outras proteínas celulares (NUBER et al., 1998) e que E6-AP, de fato, pertence a uma família de ligases estreitamente relacionada á ubiquitina (HUIBREGTSE et al., 1995; SCHWARZ et al., 1998). Tem sido relatado também que E6 estimula a degradação tanto de $c-m y c$ e bak através da interação E6-AP (THOMAS e BANK, 1998), mas nesses casos, ela parece ser apenas um intensificador de uma interação que normalmente ocorre. Na degradação de p53, E6 parece ter desviado E6-AP para um alvo incomum. A cascata de degradação de p53 por E6 pode ser evidenciada na figura 5. 


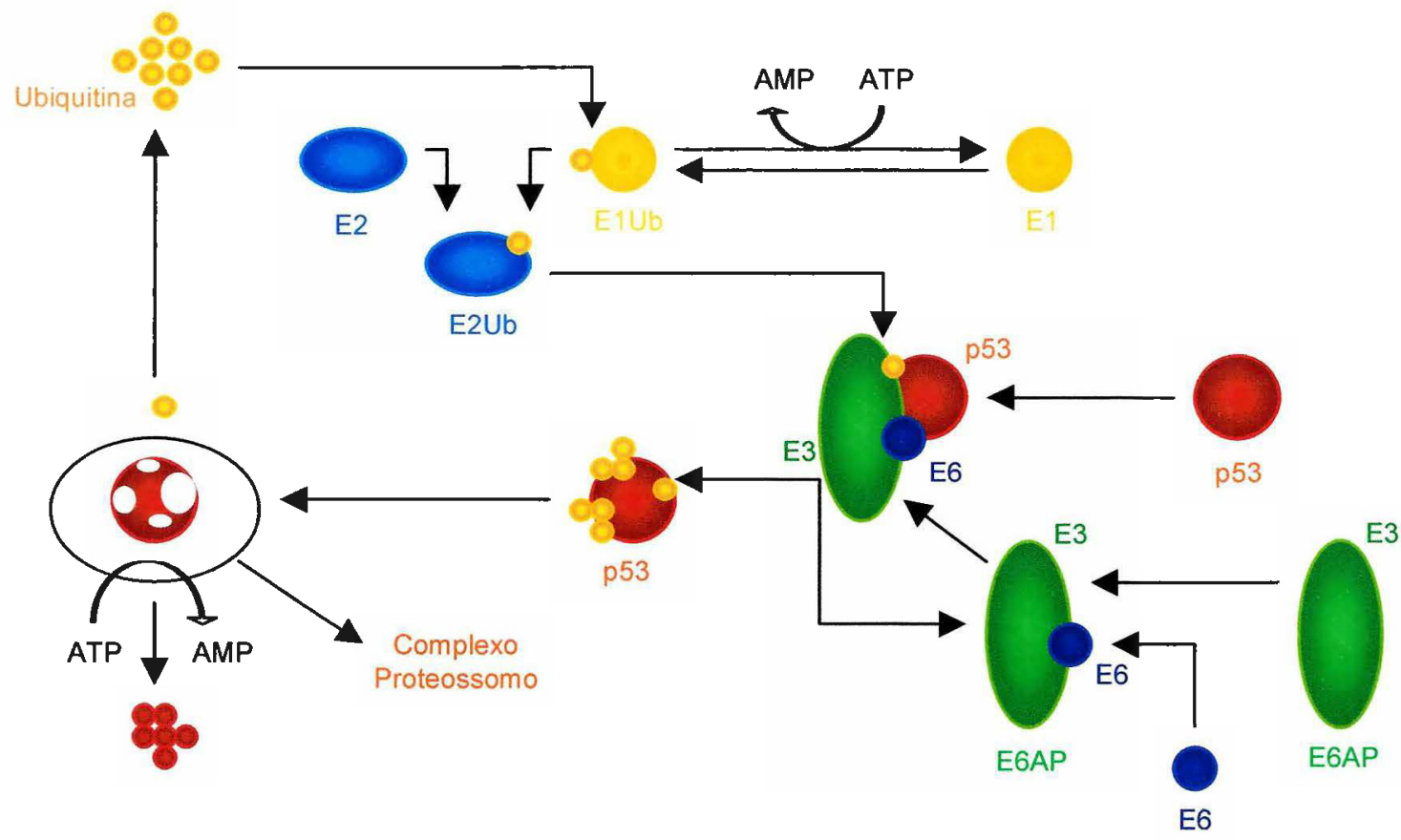

Figura 5: A proteína E6 induz a degradação de p53. A enzima E1 promove a ativação da ubiquitina, que é transferida para uma enzima conjugada E2 e esta, transfere o radical ubiquitina para a proteína ubiquitina ligase E3. E6 de HPV se liga a E6-AP, fazendo com que esta passe a ter a capacidade de transferir radicais ubiquitina para p53. p53 poliubiquitinado é degradado pelo complexo proteossomo 26S (Modificado de THOMAS et al., 1999a). 


\section{O GENE $p 53$}

\subsection{Histórico e Aspectos Gerais}

A fosfoproteína nuclear p53 foi originalmente descoberta em extratos de células transformadas pelo fato de reagir com anticorpos provenientes de animais com tumores induzidos pelo vírus símio 40 (SV40). Foi evidenciada a formação de um complexo oligomérico entre esta proteína e o antígeno T grande do SV40 em células transformadas por este vírus (LINZER e LEVINE, 1979; LANE e CRAWFORD, 1979). Pelo fato do antígeno T grande do SV40 ser necessário para a manutenção do fenótipo transformado foi sugerido que esta interação pudesse desempenhar um importante papel na transformação maligna. Dessa maneira, p53 passou a ser considerado um antígeno tumoral. A partir deste achado, foi verificado que uma grande variedade de linhagens celulares e células derivadas de tumor apresentavam grandes quantidades de p53 (de 5 a 100 vezes mais do que em células não transformadas) (LINZER e LEVINE, 1979; DELEO, et al., 1979). Além disso, em células transformadas a meia vida desta proteína é muito maior do que em células não transformadas (OREN, MALTZMAN e LEVINE, 1981; REICH, OREN e LEVINE, 1983). O fato do DNA genômico e alguns clones de DNA complementar (cDNA) de p53 possuírem a capacidade de imortalizar células em cultura (JENKINS, RUDGE e CURRIE, 1984) e ainda cooperarem com o oncogene ras ativado para transformar fibroblastos primários de embriões murinos (ELIYAHU et al., 1984; PARADA et al., 1984) fizeram com que este gene fosse considerado um oncogene.

Foi observado, entretanto, que os cDNAs de p53 com capacidade transformantes tratavam-se, na verdade, de formas mutadas do gene (HINDS, FINLAY e 
LEVINE, 1989). Dessa maneira, p53 passou a ser considerado um gene supressor de tumor, regulando negativamente o ciclo celular e exigindo completa perda de função para promover a formação tumoral.

A expressão de $p 53$ selvagem em linhagens celulares transformadas por outros oncogenes promove a reversão do fenótipo transformado nessas células (FINLEY, HINDS e LEVINE, 1989; ELIYAHU et al., 1989).

Dessa maneira, p53 passou de antígeno tumoral a oncogene e, por fim, gene supressor de tumor com função de regular negativamente o ciclo celular (LEVINE, MOMAND e FINLAY, 1991).

\subsection{Envolvimento na carcinogênese humana}

Dentre uma grande variedade de processos e vias metabólicas envolvidas na progressão maligna, o gene $p 53$ aparece como um dos principais genes envolvidos na carcinogênese humana. De fato, a via de p53 encontra-se alterada na maioria dos tumores invasivos. Essas alterações tipicamente incluem perda alélica, mutações pontuais ou inativação desta proteína por proteínas virais ou celulares. Um banco de dados destas mutações é mantido pela International Agency for Research on Cancer ou IARC (http://www.iarc.fr/p53/) (HERNANDEZ-BOUSSARD et al., 1999).

Mutações em p53 são encontradas em mais de $50 \%$ de todos cânceres humanos, compreendendo mais de 50 tipos diferentes de células e tecidos (HOLLSTEIN et al., 1994). Isto indica que a perda da atividade de p53 é um fator importante na progressão tumoral. 
O gene p53 está localizado no cromossomo 17 p13 e possui 11 exons distribuídos em $20 \mathrm{~kb}$. Aproximadamente 90\% das substituições nucleotídicas são encontradas entre os exons 5 e 8, o que corresponde a quatro dos cinco domínios evolutivamente conservados da proteína p53 (domínios II a V) (CHANG et al., 1993; LEVINE et al., 1997; OZBUN e BUTEL et al., 1995). O gene $p 53$ apresenta seis códons mais freqüentemente mutáveis. Os códons 175, 245, 248, 249, 273 e 282 são considerados regiões de maior freqüência de mutação (hotspots) e representam $20 \%$ de todas as mutações encontradas em p53. Estes códons estão localizados no domínio de ligação a seqüências específicas do DNA, o que leva a alteração da estrutura e função da proteína p53 (CHO, et al., 1994; PRIVES, 1994). Estas mutações podem ser classificadas em classe I, quando afetam diretamente os resíduos de ligação da proteína ao DNA, e em classe II, quando interferem na integridade estrutural da proteína (MAY e MAY, 1999).

Apesar de ter sido observado que o gene p53 não se mostra necessário ao desenvolvimento normal, ratos jovens com esse gene deletado sempre apresentam maior susceptibilidade ao aparecimento de tumores (DONEHOVER, 1992).

A importância de p53 como supressor tumoral é adicionalmente demonstrada em humanos com a rara síndrome autossômica dominante Li-Fraumeni. Tal síndrome apresenta como principal característica mutações heterozigotas de p53 em células germinativas. Com a perda do alelo selvagem deste gene, indivíduos portadores da síndrome, desenvolvem uma variedade de tumores mesenquimais e epiteliais em idade consideravelmente precoce (MALKIN et al., 1990). 


\subsection{Estrutura e Função}

A proteína p53 é formada por 393 aminoácidos e apresenta quatro domínios funcionais principais: A extremidade N-terminal onde se encontra o domínio de transativação transcricional (aminoácidos 1-42), a parte central onde se encontra o domínio de ligação ao DNA (aminoácidos 102-292) e a extremidade C-terminal onde se encontram o domínio de oligomerização (aminoácidos 323-356) e o domínio regulatório (aminoácidos 360-393).

O domínio de ativação transcricional da porção N-terminal confere à proteína p53 a capacidade de recrutar componentes básicos da maquinaria transcricional, incluindo proteínas ligantes de seqüências TATA (TBP), seus fatores associados (TAF) e componentes de TFIID (LU e LEVINE, 1995; THUT et al., 1995). Além disso, esse domínio também interage com a proteína RP-A e com a subunidade p62 do fator de transcrição e de reparo TFIIH (DUTTA et al., 1993).

A proteína E1B-55 $\mathrm{kDa}$, a proteína humana MDM2, a proteína $\mathrm{X}$ do vírus da hepatite B têm a capacidade de se ligar a extremidade $\mathrm{N}$-terminal de p53 inibindo sua capacidade de transativação da transcrição (YEW e BERK, 1992; OLINER et al., 1993; MOMAND et al., 1992; LEVINE, 1997).

A regulação negativa de p53 através da função de MDM2 ocorre de duas maneiras: (1) MDM2 pode se ligar ao domínio de transativação de p53 e assim inibir a habilidade de p53 de estimular a transcrição (OLINER et al., 1993; MOMAND et al., 1992); e (2) MDM2 desempenha um papel central na regulação dos níveis de p53 por desencadear a sua rápida degradação (HAUPT et al., 1997). O gene $m d m 2$ per se é 
ativado por p53, fazendo com que o controle da atividade de p53 se dê através de um mecanismo de retroalimentação negativa (WU et al., 1993).

A região amino-terminal também possui uma região altamente rica em prolina (aminoácidos 63-97) que apresenta grande similaridade com uma proteína ligante SH3. Essa região é essencial para a apoptose mediada por p53 (SAKAMURO et al., 1997), para a supressão do crescimento tumoral (WALKER e LEVINE, 1996) e para a degradação de p53 mediada por E6 (LI e COFFINO, 1996) (Figura 6).

A região central de p53 contém o domínio de ligação que reconhece seqüências alvo específicas no DNA (EL-DEIRY et al., 1992). Essa região também funciona como um domínio de ligação protéica interagindo com o antígeno $\mathrm{T}$ grande do SV40 (JENKINS et al., 1988) e com as proteínas celulares 53BP1 e 53BP2 (RUPPERT e STILLMAN, 1993; GORINA e PAVLETICH, 1996; IWABUCHI et al., 1994) (Figura 6).

A região carboxi-terminal de p53 (aminoácidos 300-393) incluem: (1) uma região ligante flexível (aminoácidos 300-318) conectando o domínio da região central e a região carboxi-terminal; e (2) um domínio de tetramerização (aminoácidos 323-356) responsável pela formação da estrutura quaternária de p53, um tetrâmero. A supressão do crescimento de células tumorais mediada por p53 e a eficiente transativação in vivo é dependente da forma tetramérica desta proteína (PIETENPOL et al., 1994) (Figura 6). 

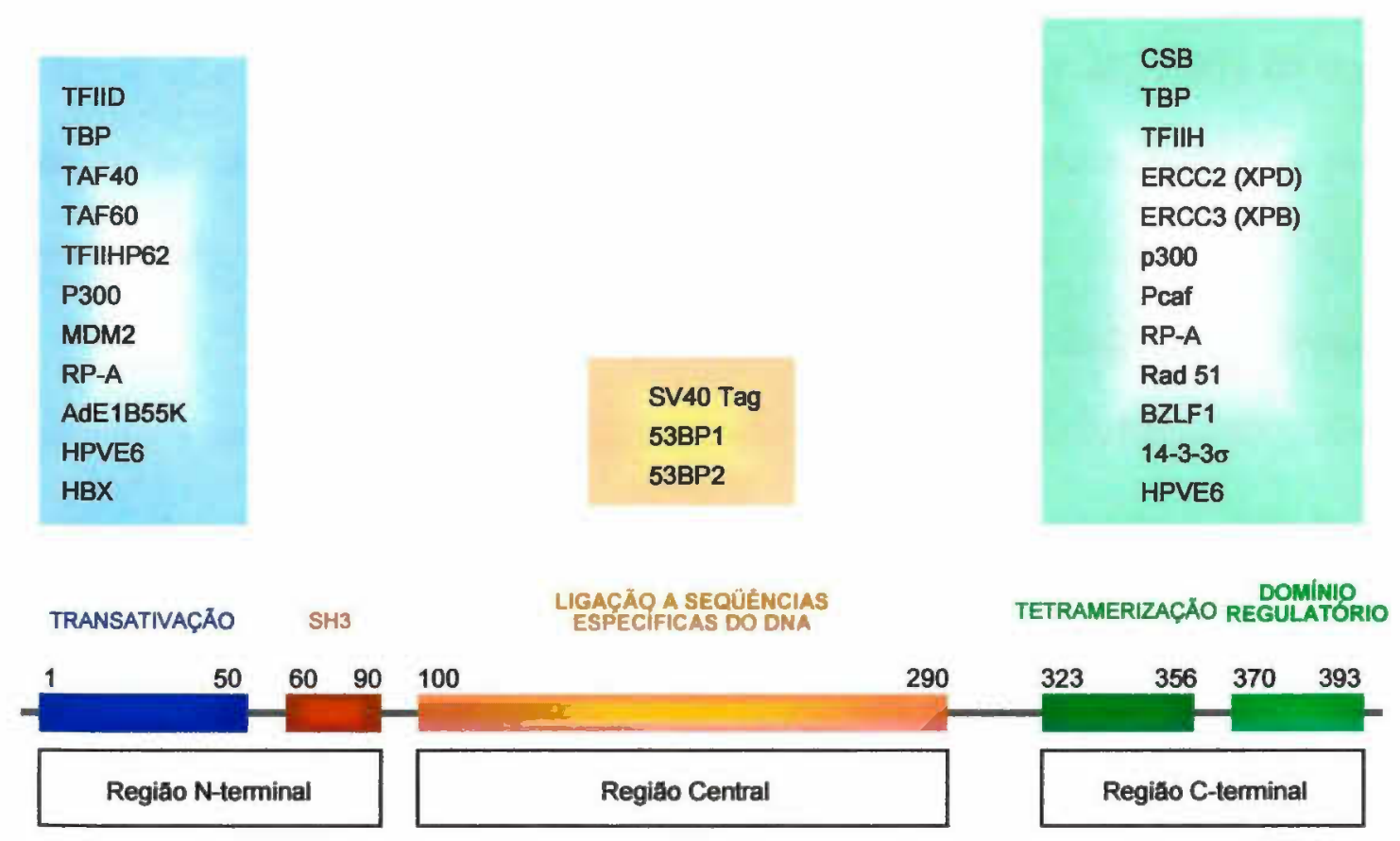

Figura 6: Representação esquemática da estrutura da proteína p53. Nas caixas superiores estão representadas as proteinas celulares e virais que interagem com os seus respectivos domínios (Modificado de MAY e MAY, 1999). 
Próximo ao domínio de oligomerização encontra-se uma região importante na promoção da apoptose (WANG et al., 1996), um domínio de regulação transcricional (WANG e PRIVES, 1995) ou um domínio de reconhecimento de DNA danificado.

A ativação de p53 em células de mamíferos tem sido correlacionada a fosforilação (KO e PRIVES, 1996), acetilação (SAKAGUSHI et al., 1998), glicosilação (SHAW et al., 1996) e remoção proteolítica (OKOROKOV et al., 1997) do domínio carboxi-terminal. Essas modificações provocam mudanças conformacionais na proteína promovendo, dessa maneira, a ativação de p53.

Uma vez ativado este gene promove a parada do ciclo celular impedindo, portanto, a proliferação descontrolada (revisado BÁLINT e VOUSDEN, 2002). Além da parada do ciclo celular, p53 é responsável também por processos que levam a senescência, diferenciação e apoptose e cada um desses processos é controlado tanto por fatores celulares intrínsecos quanto extrínsecos. Em alguns casos, p53 também está envolvido no reparo de danos no DNA provocados por stress genotóxico. Entretanto, na grande maioria desses casos a indução de $p 53$ leva a uma inibição irreversível do crescimento celular, mais precisamente por indução de apoptose (VOUSEN e LU, 2002).

A ação de p53 em mecanismos de reparo de DNA foi evidenciada pela observação de que essa proteína torna-se ativa e acumula-se em células submetidas à radiação ionizante (LU e LANE, 1993). Este acúmulo ocorre em resposta a quebras na dupla fita do DNA promovido pela atividade deste agente genotóxico. Através de seu domínio regulatório, localizado na extremidade C-terminal, p53 se liga fortemente a essas quebras (NELSON e KASTAN, 1994) e isso promove a ativação e estabilização das proteínas. 
Em algumas células, a indução de p53 em resposta a radiação ionizante resulta numa parada transitória na fase G1 do ciclo celular. A irreversibilidade dessa parada pode ser atribuída a incapacidade dessas células de reparar o dano provocado pela radiação (HUANG et al., 1996).

A parada do ciclo celular em G1 promovida por p53 é mediada pela atividade de outra proteína conhecida como p21/WAF1 (EL-DEIRY et al., 1993). p53 promove a transativação de $\mathrm{p} 21 / \mathrm{WAF} 1$ e esta, por sua vez, inibe a atividade de quinases dependentes de ciclina (CDK), incluindo ciclina D-CDK 4/6, ciclina E-CDK 2 e ciclina A-CDK2. A inibição dessas proteínas impede a fosforilação de $\mathrm{pRB}$ e, dessa maneira, o fator de transcrição E2F não é liberado e a transcrição de genes essenciais à progressão do ciclo celular não ocorre.

O mecanismo bioquímico pelo qual p53 induz apoptose é ainda alvo de algumas controvérsias, uma vez que não está claro se a transcrição mediada por p53 está envolvida neste processo (CAELLES et al., 1994; HAUPT et al., 1995). Tem sido relatado que a apoptose dependente de p53, em resposta ao dano no DNA, é independente de síntese de novos RNA ou proteínas (CAELLES et al., 1994). De modo controverso, tem sido mostrado que p53 pode induzir a expressão dos genes bax (MIYASHITA e REED, 1995) e $c d 95 /$ fas (OWEN-SCHUB et al., 1995), ambos promotores de apoptose. 


\subsection{Polimorfismo do Códon 72 do Gene p53}

O gene $p 53$ apresenta polimorfismos distintos em diversos grupos étnicos e tem sido amplamente estudado tanto em tecidos normais quanto em tecidos tumorais (HILLEBRANDT et al., 1997), possuindo pelo menos 10 polimorfísmos diferentes, localizados nas suas regiões: codificadoras (códon $21,36,47,72,213$ ) e não codificadora (introns 1, 3, 6, 7) (WESTON et al., 1997). O polimorfismo do códon 72 do gene $p 53$ é o mais estudado.

O códon 72 do gene p53 está localizado no exon 4, dentro do domínio funcional de ligação do SH3 (WALKER e LEVINE, 1996). O domínio SH3 contém cinco repetições de seqüências $\operatorname{PXXP}$ ( $\mathrm{P}$ designado para prolina e X para outro aminoácido qualquer). Este domínio rico em prolina é essencial para a eficiente supressão do crescimento celular (WALKER e LEVINE, 1996) e indução de apoptose mediada por p53 (SAKAMURO et al., 1997).

O polimorfismo do códon 72 do gene $p 53$ apresenta três variantes: arginina (Arg, CGC), prolina (Pro, CCC) e cisteína (Cys, TGC) (MATLASHEWSKI et al., 1987b). A proteína que apresenta a variante arginina (p53Arg) difere estruturalmente da variante prolina (p53Pro) (MATLASHEWSKI, et al., 1987b), contudo, essa diferença não altera a sua atividade biológica (MOREAU e MATLASHEWSKI, 1992). A variante cisteína, por sua vez, é extremamente rara.

Dado que essa região é funcionalmente importante para a atividade de p53, THOMAS e colaboradores (1999b) examinaram ao nível bioquímico e biológico se essas duas variantes se comportavam de maneira diferente. Verificaram que ambas tratavam-se de variantes selvagens uma vez que ambas eram capazes de se ligar a uma variedade de 
seqüências do DNA, em níveis equivalentes. Contudo, foi notada uma sutil diferença em suas habilidades de interagir com elementos básicos da maquinaria transcricional. Em adição, existem também diferenças na habilidade de cada forma induzir apoptose e suprimir o crescimento de células transformadas. Esses resultados demonstraram que essas duas variantes não são funcionalmente equivalentes, e isso poderia ter implicações importantes para o monitoramento de pacientes com tumores contendo $p 53$ selvagem.

Foi evidenciado também que quando a variante p53Arg encontra-se mutada apresenta maior afinidade pela proteína $\mathrm{p} 73$ do que a variante p53Pro (MARIN et al., 2000). p73 é um homólogo de p53 responsável pela indução da apoptose em células deficientes para este gene. MARIN e colaboradores também observaram que a afinidade de p53Arg mutada por p73 é maior do que a afinidade de p53Arg selvagem por este homólogo de p53. Isso sugere que mutações em p53Arg fazem com que esta variante apresente um ganho de função, em comparação a variante p53Pro, na atividade inibitória de $\mathrm{p} 73$. Além disso, em câncer de pele a variante p53Pro parece ter efeito protetor e isso pode ser correlacionado ao fato desta forma ser mais comumente encontrada em populações negróides. De fato, estudos realizados em diferentes grupos étnicos demonstraram que a freqüência alélica da variante prolina é mais alta nas populações negras da África (63\%) e da América (61\%), seguida da população do sul da Índia (54\%) e da China (38\%), enquanto que na população caucasiana varia de 17 a $34 \%$ (BECKMAN et al., 1994).

Este polimorfismo também tem sido pesquisado em diversos tipos de cânceres, como o de pulmão (JIN et al., 1995), ovário (BULLER et al. 1997), nasofaríngeo (BIRGANDER et al., 1996), coloretal, estômago, bexiga e mama 
(WESTON et al., 1997), colo de útero e de pele (STOREY et al., 1998), correlacionando a freqüência alélica nos grupos étnicos com a predisposição ao câncer e possível utilização como marcador tumoral.

No caso do câncer de colo uterino, STOREY e colaboradores (1998) demonstraram que a proteína p53 contendo no códon 72 para o aminoácido arginina era mais susceptível à degradação promovida por E6 do que a proteína contendo para o aminoácido prolina. Neste trabalho, esses autores demonstraram que a interação da proteína E6 de HPV de baixo risco não degrada a proteína p53 com a variante prolina, mas degrada p53 com a variante arginina, sendo que esta degradação não é tão eficiente quanto àquela decorrente da interação com E6 de HPV de alto risco. Além disso, este mesmo estudo verificou que os pacientes homozigotos para Arg têm maior risco de desenvolver uma lesão maligna de câncer cervical associado ao HPV quando comparados aos portadores heterozigotos e homozigotos para prolina.

Esses resultados, entretanto, são alvos de grande controvérsia. Um grande número de estudos subseqüente não encontrou a mesma associação (BAEK et al., 2000; BASTIENS et al., 2001; BERTORELLE et al., 1999; CALHOUN et al., 2002; DYBIKOWSKA et al., 2000; GIANNOUDIS et al. 1999; GUSTAFSSON et al., 2001; HAYES et al., 1998; HELLAND et al., 1998; HILDESHEIM et al., 1998; JOSEFSSON et al., 1998; KIM et al., 2001; KLAES et al., 1999; KUCERA, et al., 2000; LANHAM et al., 1998; MADELEINE et al., 2000; MALCOLM et al., 2000; MINAGUCHI et al., 1998; NGAN et al., 1999; NGAN et al., 2000; NISHIKAWA et al., 2000; PEGORARO, et al., 2000; REZZA et al., 2001; ROSENTHAL et al., 1998; SKARKA, et al., 1999; SONODA et al., 1999; SUAREZ-RINCON et al., 2002; TACHEZY et al., 1999; TENTI 
et al., 2000; TONG et al., 1999; WANG et al., 1999; WONG et al., 2000; YAMASHITA et al., 1999). Contudo, estudos mostrando resultados semelhantes aos encontrados por STOREY e colaboradores continuam a ser publicados (AGORASTOS et al., 2000; ANDERSSON, et al., 2001; DOKIANAKIS e SPANDIDOS, 2000; MAKNI et al., 2000; PEGORARO et al., 2002; SARANATH et al., 2002; VAN DUIN et al., 2000; ZEHBE et al., 1999; ZEHBE et al., 2001). Existem ainda publicações recentes que não descartam a possibilidade do polimorfismo do códon 72 do gene p53 estar associado com o risco de desenvolvimento de lesão (KLUG et al., 2001; SKARKA et al., 2000). Entretanto, essa associação parece ser independente da presença do HPV. Mais recentemente, foi evidenciada, pela primeira vez, a interação entre o genótipo prolina e risco aumentado de carcinoma do colo uterino (BHATTACHARYA, DUTTAGUPTA e SENGUPTA, 2002).

No trabalho de MAKNI e colaboradores (2000) foi avaliado o efeito de variações intra e interlaboratoriais e foi possível constatar que erros classificatórios poderiam influenciar a associação entre o polimorfismo do códon 72 do gene p53 e o risco de neoplasia da cérvice uterina. Neste trabalho o polimorfismo do códon 72 foi identificado por três laboratórios diferentes utilizando a mesma metodologia de detecção. A discordância dos resultados foi consideravelmente significativa sugerindo que a metodologia utilizada poderia levar a erro na classificação das amostras. Pelo fato da maioria dos trabalhos publicados terem utilizado diferentes metodologias de detecção do polimorfismo do códon 72 , houve a necessidade de investigar se os resultados discordantes da literatura poderiam ser devidos a erros de classificação dependentes de metodologia. 


\section{OBJETIVOS}

O presente trabalho teve como objetivos:

- Comparar metodologias de deteç̧ão do polimorfismo do códon 72 do gene p53.

- Determinar se o polimorfismo do códon 72 do gene p53 poderia estar associado com infecções persistentes por HPV e risco de neoplasia do colo uterino. 


\section{MATERIAIS E MÉTODOS}

\section{AMOSTRAS CLÍNICAS}

O DNA das amostras foi isolado de esfregaços cervicais pertencentes ao estudo epidemiológico prospectivo Ludwig/McGill que tem por objetivo determinar os fatores de risco da persistência de HPV na cérvice uterina. Este estudo vem sendo conduzido no Instituto Ludwig de Pesquisa sobre o Câncer, sob a responsabilidade da Dra. Luisa Lina Villa em colaboração com o Dr. Eduardo Franco (McGill University, Montreal, Canadá) (FRANCO et al, 1999; SCHLECHT, et al., 2001). Todos os espécimes foram obtidos após consentimento expresso das pacientes. Tal estudo foi aprovado pelos comitês de ética dos hospitais e instituições envolvidos. Os documentos mencionados estão arquivados nesta instituição.

As mulheres foram selecionadas e atendidas pelas clínicas de ginecologia e planejamento familiar do Hospital Vila Nova Cachoeirinha e mais recentemente, no Hospital do Câncer, São Paulo. O critério para inclusão dessas mulheres no estudo prospectivo foi idade entre 18 e 60 anos de idade, não estar, e nem pretender ficar grávida no período de 24 meses de admissão, não ter sido submetida a histerectomia, e ser residente na cidade de São Paulo.

O estudo iniciou-se em 1993 e aproximadamente 2.500 mulheres estão sendo acompanhadas por um período de cinco anos. Durante o primeiro ano de seguimento as visitas foram realizadas a cada 4 meses, sendo semestrais as visitas durante os 4 anos subseqüentes (FRANCO et al., 1999). 
Em cada visita são preenchidos questionários epidemiológicos e coletados esfregaços cervicais para citologia e detecção de DNA de HPV. As informações contidas nos questionários abrangem todas as classes de fatores de risco conhecidos para a infecção por HPV e neoplasia cervical, incluindo variáveis sócio-demográficas, vida reprodutiva, hábitos sexuais, fumo e dieta. A detecção e caracterização do genótipo viral presente no espécime são realizadas através de PCR seguida por hibridização com sondas específicas (TING e MANOS, 1990), complementadas por análise de RFLP (BERNARD et al., 1994). Caso a detecção de DNA de HPV seja positiva, avalia-se a infecção como sendo persistente (duas ou mais amostras positivas para o mesmo tipo de HPV ao longo do primeiro ano) ou transiente (com um único resultado positivo ao longo do seguimento). A definição precisa de persistência está sendo verificada através do seqüenciamento de regiões do genoma viral, que definem variantes dentro de um mesmo genótipo de HPV. Neste estudo também está sendo estimada a carga viral em cada espécime positivo para DNA de HPV. Em cada visita, também são coletadas amostras de sangue das pacientes para realização de análises sorológicas, incluindo a detecção de anticorpos IgG e IgM contra a proteína Ll do HPV. Todas as etapas experimentais mencionadas estão sendo realizadas no Instituto Ludwig de Pesquisa sobre o Câncer de São Paulo por estudantes de pós-graduação e técnicos de pesquisa.

Para avaliar se o polimorfismo do códon 72 poderia ser utilizado como indicativo para a progressão ao câncer cervical, 978 amostras provenientes deste estudo foram selecionadas de acordo com o critério de positividade para HPV nas duas primeiras visitas, isto é, à admissão ao estudo e após 4 meses de seguimento. 


\section{TESTE PARA HPV}

Esta etapa foi realizada anteriormente a este projeto por outros pesquisadores do nosso grupo no Instituto Ludwig de Pesquisa sobre o Câncer.

\subsection{Isolamento de DNA dos esfregaços do colo uterino}

As amostras de esfregaços de colo de útero, que foram colhidas com escovas do tipo citobrush, foram imediatamente colocadas em $2 \mathrm{ml}$ de tampão T.E. (Tris $10 \mathrm{mM} \mathrm{pH}=7,4$, EDTA $1 \mathrm{mM})$ e, em seguida, estocadas a $-20^{\circ} \mathrm{C}$ até a etapa de purificação do DNA. Para esta purificação, as amostras foram inicialmente digeridas com proteinase $\mathrm{K}(200 \mu \mathrm{g} / \mathrm{ml})$, por 12 horas a $37^{\circ} \mathrm{C}$. Num segundo passo, essa proteinase foi submetida a inativação permanecendo por 10 minutos a $95^{\circ} \mathrm{C}$. A purificação do DNA foi realizada utilizando-se colunas de troca iônica Glass Max DNA Isolation Spin Cartridge System (Gibco/BRL, Gaithersburg, MD, USA). Este método se baseia na ligação do DNA a uma membrana na presença de NaI. As impurezas residuais que permaneceram em solução, foram retiradas por centrifugação e a separação do DNA foi feita passando-se vários volumes de tampão de lavagem pela membrana. O DNA purificado foi estocado em $50 \mu \mathrm{l}$ de tampão T.E.

Após a purificação as amostras foram submetidas a PCR (reação de polimerização em cadeia) utilizando os iniciadores genéricos MY9/11 (MANOS et al., 1989). Estes iniciadores promovem a amplificação de uma região muito conservada de $450 \mathrm{pb}$ do gene L1 de diversos tipos de HPV genitais. As amostras também foram amplificadas utilizando os iniciadores GH20 e PCO4 (SAIKI et al., 1988) que 
amplificam $268 \mathrm{pb}$ do gene da $\beta$-globina, servindo como controle interno para a avaliação da integridade e da suficiência de DNA de cada amostra. A identificação dos diferentes tipos de HPV foi feita por hibridização alelo-específica (dot blot) utilizando-se 28 sondas HPV tipo-específicas (BAUER et al., 1993; TING \& MANOS, 1990), ou através da digestão do produto de PCR por enzimas de restrição (ER) (BERNARD et al., 1994), baseado no polimorfismo do comprimento dos fragmentos de restrição (RFLP) entre diversos tipos de HPV. Este método é capaz de identificar mais de 40 tipos de HPV.

\section{DETERMINAÇÃO DO GENÓTIPO DE p53 PARA O CÓDON 72}

O genótipo de p53 para o códon 72 foi determinado utilizando-se diferentes metodologias, todas baseadas em PCR. A amplificação do exon 4 de p53 serviu de passo inicial para a identificação do polimorfismo do códon 72 por hibridização alelo-específica, DHPLC - Denaturating High Performance Liquid Chromatography ou Cromatografia Líquida Desnaturante de Alta Resolução, RFLP e seqüenciamento direto. A amplificação alelo-específica também foi utilizada para identificação deste polimorfismo.

\subsection{PCR para o exon 4 de p53}

A padronização da amplificação do exon 4 de p53 se fez necessária uma vez que outras metodologias dependentes desta amplificação eram influenciadas pela qualidade do produto desta PCR. Dessa maneira, vários protocolos de amplificação foram testados e o mais adequado é descrito a seguir. 
Para reação de amplificação foi utilizado: $1 \mu$ de cada oligonucleotídeo p53+ (5' -TCCCCCTTGCCGTCCCAAG- 3') e p53- (5' -CGTGCAAGTCACAGACTT3') na concentração de 20 pmoles/ $\mu \mathrm{l} ; 1,5 \mathrm{mM}$ de $\mathrm{MgCl}_{2} ; 50 \mathrm{mM} \mathrm{KCl} ; 10 \mathrm{mM}$ TRIS-HCL (pH 8,5); $200 \mathrm{mM}$ de cada dNTP, 2 U de Taq Gold DNA Polimerase (Applied Biosystems-ROCHE, New Jersey, USA) e quantidades variáveis de DNA, num volume final de $50 \mu l$.

O esquema de ciclagem ideal foi obtido através da adição de ciclos curtos com diferentes temperaturas de anelamento. Esta ciclagem apresentava um passo inicial de $95^{\circ} \mathrm{C}$ por 10 minutos, seguido por 10 ciclos com desnaturação a $95^{\circ} \mathrm{C}$ por 1 minuto, anelamento a $58^{\circ} \mathrm{C}$ por 1 minuto e extensão a $72^{\circ} \mathrm{C}$ por 1 minuto; 15 ciclos de desnaturação a $95^{\circ} \mathrm{C}$ por 1 minuto, anelamento a $56^{\circ} \mathrm{C}$ por 1 minuto e extensão a $72^{\circ} \mathrm{C}$ por 1 minutos e 15 ciclos de desnaturação a $95^{\circ} \mathrm{C}$ por 1 minuto, anelamento a $53^{\circ} \mathrm{C}$ por 1 minuto e extensão a $72^{\circ} \mathrm{C}$ por 1 minuto. Um passo de extensão final $\left(72^{\circ} \mathrm{C}\right.$ por 3 minutos) e um passo adicional $\left(95^{\circ} \mathrm{C}\right.$ por 10 minutos) foram adicionados, sendo esse último recomendado para realização da técnica de DHPLC. As reações foram realizadas num ciclador de temperatura programável do tipo TC-341 (Amersham Pharmacia Biotech, Buckinghamshire, ENGLAND).

Para o controle da amplificação, uma alíquota de $5 \mu \mathrm{l}$ de todas as amostras amplificadas foi submetida à eletroforese em gel de agarose $1,5 \%$ em tampão TBE 1X. Para identificação do produto amplificado foi utilizado como corante brometo de etídio.

A partir do procedimento descrito acima foi possível a obtenção de um produto de PCR sem as variações significativas observadas em outras etapas de padronização. Dessa maneira, foi possível estabelecer com precisão a melhor condição 
para amplificação do exon 4 de p53 necessária para realização de outras metodologias dependentes de PCR. A tabela 1 sumariza as condições ideais de amplificação.

Tabela 1. Padrão de ciclagem e de reagentes utilizados para amplificação do exon 4 de p53.

\begin{tabular}{|c|c|c|}
\hline Passos & Temperatura & Tempo (minutos) \\
\hline 1. & $95^{\circ} \mathrm{C}$ & 10 \\
\hline 2. & $95^{\circ} \mathrm{C}$ & 1 \\
\hline 3. & $58^{\circ} \mathrm{C}$ & 1 \\
\hline 4. & $72^{\circ} \mathrm{C}$ & 1 \\
\hline \multicolumn{3}{|c|}{$\mathrm{N}^{\circ}$ de repetições $(2$ a 4$)=10$} \\
\hline 5. & $95^{\circ} \mathrm{C}$ & 1 \\
\hline 6. & $56^{\circ} \mathrm{C}$ & 1 \\
\hline 7. & $72^{\circ} \mathrm{C}$ & 1 \\
\hline \multicolumn{3}{|c|}{$N^{\circ}$ de repetições $(5$ a 7$)=15$} \\
\hline 10. & $95^{\circ} \mathrm{C}$ & 1 \\
\hline 11. & $53^{\circ} \mathrm{C}$ & 1 \\
\hline 12. & $72^{\circ} \mathrm{C}$ & 1 \\
\hline \multicolumn{3}{|c|}{$\mathrm{N}^{\circ}$ de repetições $(10$ a 12$)=15$} \\
\hline 14. & $72^{\circ} \mathrm{C}$ & 3 \\
\hline 15. & $95^{\circ} \mathrm{C}$ & 10 \\
\hline
\end{tabular}

\begin{tabular}{lc}
\hline Reagentes & Concentrações \\
\hline Tris- $\mathrm{HCl}(\mathrm{pH}=8,5)$ & $10 \mathrm{mM}$ \\
$\mathrm{KCl}$ & $50 \mathrm{mM}$ \\
$\mathrm{MgCl}_{2}$ & $1,5 \mathrm{mM}$ \\
Iniciadores (p53+ e p53-) & $0,5 \mu \mathrm{M}$ \\
Taq Gold DNA polimerase & $2 \mathrm{U} / \mu 1$ \\
dNTPs $(\mathrm{dATP}, \mathrm{dTTP}, \mathrm{dCTP}, \mathrm{dGTP})$ & $200 \mathrm{mM}$ \\
DNA molde & variável \\
\hline
\end{tabular}




\subsection{Hibridização Alelo-específica}

Uma vez padronizada a reação de PCR, foi possível a padronização das melhores condições de hibridização alelo-específica necessárias à identificação dos alelos do códon 72 de p53. As condições ideais que permitiram a identificação deste polimorfismo nas amostras testadas estão descritas abaixo.

Inicialmente, 1,5 microlitros de cada produto de PCR (pertencentes a amostras e controles) foi aplicado manualmente a membranas de nylon Hybond $\mathrm{N}^{+}$ (Amersham, Pharmacia Biotech, Buckinghamshire, ENGLAND). Em seguida, estas membranas foram desnaturadas em NAOH $0,4 \mathrm{M}$ por 5 minutos e hidratadas em 3x SSPE $\left(3,6 \mathrm{M} \mathrm{NaCl}, 0,2 \mathrm{M} \mathrm{NaH}_{2} \mathrm{PO}_{4}{ }^{-} \mathrm{H}_{2} \mathrm{O}, 0,11 \mathrm{M} \mathrm{NaOH}, 0,02 \mathrm{M}\right.$ EDTA ajustado para $\left.\mathrm{pH}=7,4\right)$ por 3 minutos. Para a fixação das amostras nas membranas, estas foram expostas à luz ultravioleta no UV Crosslinker (Fisher Biotech, Pittsburgh, USA). Foram feitas três réplicas de cada membrana e estas foram estocadas em $2 x \operatorname{SSPE}$, a $4^{\circ} \mathrm{C}$, até o momento da hibridização.

Para discriminação dos alelos e genótipos, as membranas eram hibridizadas com sondas oligonucleotídicas biotiniladas. Para discriminação do alelo que codifica para o aminoácido arginina foi utilizada sonda p53ARG (5, GGGCCACGCGGGGAGCA- 3') e para o alelo que codifica para o aminoácido prolina foi utilizada sonda p53PRO (5' -GGGCCACGGGGGGAGCA- 3').

A hibridização das amostras com as respectivas sondas foi realizada em fornos de hibridização próprios (Hybaid), tipo rostisserie, onde as membranas eram colocadas em frascos cilíndricos, na temperatura adequada a cada passo. Cada membrana ocupava um frasco. 
Ambas sondas foram utilizadas na concentração de 1,2 pmoles $/ \mathrm{ml}$. Entretanto, as mesmas não apresentavam temperatura de hibridização semelhante. Assim, enquanto para sonda p53Arg era necessária a temperatura de $62^{\circ} \mathrm{C}$, para sonda p53Pro era necessária a temperatura de $64^{\circ} \mathrm{C}$. Uma terceira membrana, utilizada como controle, foi hibridizada no mesmo frasco com as duas sondas. Nesta etapa foi utilizada uma temperatura intermediária, ou seja, $63^{\circ} \mathrm{C}$.

Para determinação dos genótipos de p53 foi utilizado o seguinte protocolo de hibridização:

1. Etapas realizadas na temperatura de hibridização

a. Bloqueio em $15 \mathrm{ml}$ de SSPE $0,1 \times \operatorname{SDS} 0,5 \%$, por 20 minutos;

b. Pré-hibridização em $15 \mathrm{ml}$ de SSPE 2x SDS 0,1\%, por 20 minutos;

c. Adição das sondas à solução de pré-hibridização (SSPE 2x

$\operatorname{SDS} 0,1 \%)$

d. Lavagem de alto rigor em $15 \mathrm{ml}$ de SSPE $2 \mathrm{x}$ SDS $0,1 \%$, aquecido à temperatura de hibridização, por 2 vezes de 15 minutos;

2. Etapas realizadas à temperatura ambiente:

e. Incubação das membranas em $500 \mathrm{ml}$ de solução contendo $8 \mu l$ do conjugado Streptavidine Horse Radish Peroxidase $(1 \mathrm{mg} / \mathrm{ml}$; Vector Laboratories, Burlingame, California.).

f. Lavagem das membranas em $500 \mathrm{ml}$ de SSPE $2 x \operatorname{SDS} 0,1 \%, 2$ lavagens de 10 minutos;

Para revelação era utilizado o kit ECL (enhanced chemiluminescence direct nucleic acid labelling and detection system) (Amersham, Pharmacia Biotech, 
Buckinghamshire, ENGLAND). Em resumo, as membranas foram colocadas sob uma folha de papel de transparência de plástico e submersas por $2 \mathrm{ml}$ dos reagentes de deteç̧ão 1 e 2 em uma proporção de 1:1, por 1 minuto. Em seguida, as membranas foram cobertas por outra folha de papel transparência e expostas a um filme de raio-X $(K O D A K)$ por um tempo que variou de 5 a 20 minutos. Após esse período, os filmes foram mergulhados em revelador por 45 segundos, seguido de uma imersão rápida em água, fixador por 2 minutos, lavagem em água por 5 minutos e posterior secagem dos mesmos.

As condições ideais de hibridização alelo-específica para a discriminação dos alelos do códon 72 do gene $p 53$ estão resumidas na tabela 2 .

Tabela 2. Condições ideais utilizadas na identificação dos alelos do códon 72 de $p 53$ pelo método de hibridização alelo-específica.

\begin{tabular}{|l|c|c|}
\cline { 2 - 3 } \multicolumn{1}{c|}{} & p53ARG & p53PRO \\
\hline Temperatura & $62^{\circ} \mathrm{C}$ & $64^{\circ} \mathrm{C}$ \\
\hline Concentração de Sonda & \multicolumn{2}{|c|}{1,2 pmoles $/ \mathrm{ml}$} \\
\hline Exposição & de 5 minutos a 20 minutos \\
\hline
\end{tabular}

\subsection{DHPLC}

Baseada na técnica de HPLC (High Pressure Liquid Chromatography ou Cromatografia Liquida de Alta Pressão) de fase reversa, esta metodologia diferencia-se pelo fato do produto analisado ser submetido a condições desnaturantes (CARGILL et al., 1999). 
Nesta técnica, realizada no "WAVE® DNA Fragment Analysis System" (Transgenomic, INC., Ohama, USA), o produto de PCR é conduzido por um fluxo de tampões através de um sistema de cromatografia por coluna. A separação é dada pela eluição diferencial deste produto na matriz (fase estacionária). Os fragmentos são detectados através de uma luz ultravioleta e o resultado é dado na forma de um cromatograma.

O princípio de detecção do polimorfismo de p53 é baseado na TMHA (Temperature Modulated Heteroduplex Analysis ou Análise da Formação de Heteroduplexes por Modulação de Temperatura). Indivíduos que são heterozigotos tem uma razão de 1:1, tanto do alelo que codifica para o aminoácido arginina quanto do alelo que codifica para o aminoácido prolina. O aquecimento de todas as amostras a uma temperatura de $95^{\circ} \mathrm{C}$ seguido de um resfriamento gradativo propicia a formação de uma mistura de homoduplexes e heteroduplexes (Figura 7), que podem ser detectados pelo diferente padrão de eluição no sistema utilizado. Amostras homozigotas, não apresentam formação de heteroduplexes e apresentam assim, padrão de eluição único. 


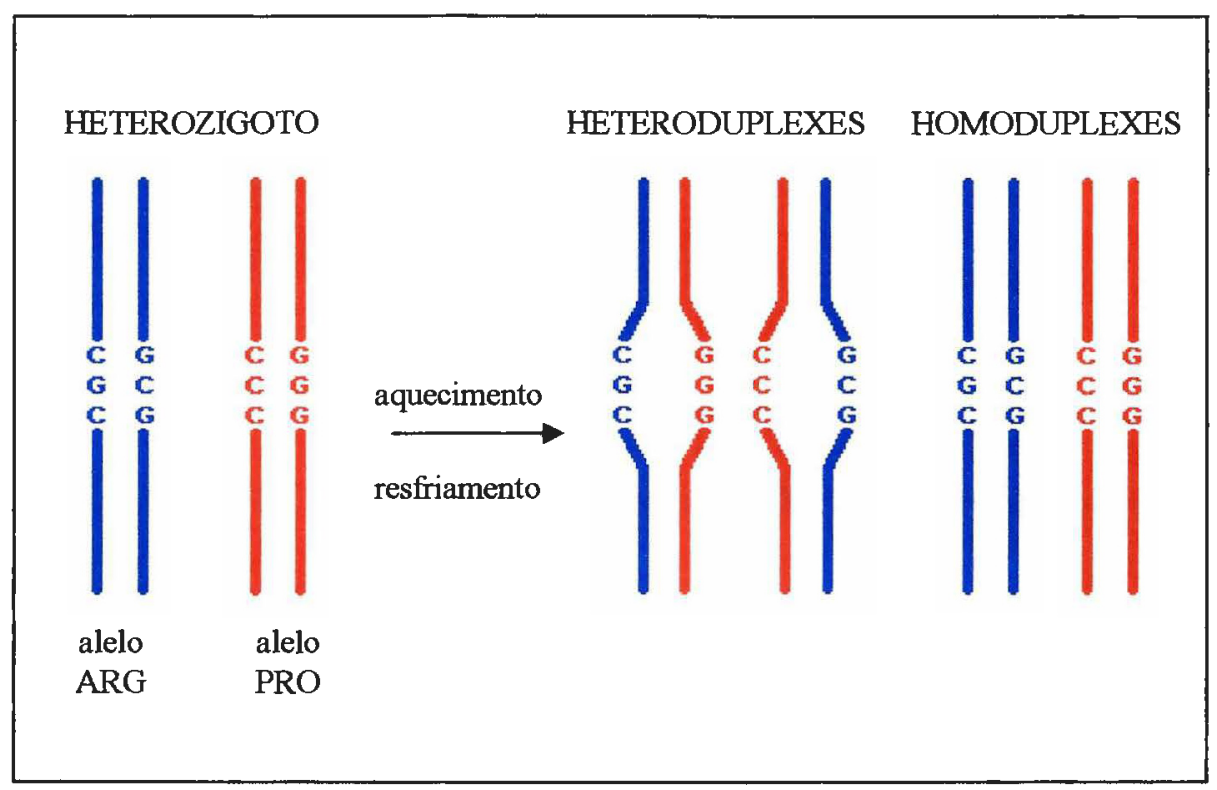

Figura 7. Representação esquemática da formação de heteroduplexes através da formação de heteroduplexes por modulação de temperatura. 
A análise no sistema utilizado foi realizada numa temperatura suficiente para desnaturação parcial das amostras. A temperatura mais adequada para identificação dos genótipos de p53 para o códon 72 foi $59^{\circ} \mathrm{C}$.

Numa primeira triagem é possível diferenciar amostras heterozigotas e homozigotas. Entretanto, para saber que tipo de alelos está presentes nas amostras homozigotas é necessária uma segunda triagem. Nesta etapa, o produto de PCR de uma amostra controle de genótipo conhecido foi adicionado à amostra teste e submetido a TMHA $\left(95^{\circ} \mathrm{C}\right.$ por 10 minutos). Essa mistura foi então submetido à DHPLC.

\subsection{RFLP}

Esse procedimento inclui a digestão do produto de PCR por enzimas de restrição (ER) específicas. Esta digestão propicia a formação de fragmentos de diferentes tamanhos mediante a seqüência de clivagem que estas ER reconhecem. Neste trabalho foram utilizadas duas ER, uma capaz de clivar o produto amplificado do alelo p53Arg (BstUI) e uma para o produto amplificado do alelo p53Pro (BsaJI) (Tabela 3).

O exon 4 de p53 foi amplificado segundo o protocolo descrito e, após a visualização do produto em gel de agarose $1,5 \%$, submetido a digestão com uma das enzimas mencionadas acima.

Para cada $7 \mu 1(15 \%)$ do produto de PCR foram adicionados $1 \mu 1$ do tampão de digestão (50 mM NaCl, $10 \mathrm{mM}$ Tris-HCl-pH $=7,9,10 \mathrm{mM} \mathrm{MgCl}_{2}, 1 \mathrm{mM}$ DTT), 5U de enzima em um volume final de $10 \mu \mathrm{l}$. Ambas enzimas apresentam atividade a $60^{\circ} \mathrm{C}$. 
O produto da digestão com a ER $B s t U I$ foi analisado em gel de poliacrilamida $8 \%$ e corados por nitrato de prata (SANGUINETTI et al., 1994). O produto da digestão com a ER BsaJI foi melhor observado em gel de poliacrilamida $12 \%$.

Tabela 3. Enzimas de Restrição utilizadas na digestão do exon 4 de p53.

\begin{tabular}{|c|c|c|c|}
\hline \multirow[t]{2}{*}{ Códon 72 do gene p53 } & \multirow[t]{2}{*}{ Enzimas } & \multirow[t]{2}{*}{ Sítios de Restrição } & Fragmentos de Restrição \\
\hline & & & Tamanho (pb) \\
\hline p53Arg & Bst UI & $5^{\prime} \ldots \mathrm{CG}^{-} \mathrm{CG} . . .3^{\prime}$ & $160+119$ \\
\hline p53Pro & BsaJI & $5^{\prime} \ldots C^{-} N_{N G G} . .3^{\prime}$ & $94+66+44+41+34$ \\
\hline
\end{tabular}

A tabela 4 resume as condições necessárias para digestão do exon 4 de p53 com as enzimas Bst UI e BsaJI.

Tabela 4. Condições de digestão ideais para as diferentes ER utilizadas.

\begin{tabular}{lcc} 
& Bst $\overline{\mathbf{U I}}$ & BsaJI \\
\hline Digestão & $60^{\circ} \mathrm{C} / 2 \mathrm{~h}$ & \\
Concentração de Enzima & $0,5 \mathrm{U} / \mu 1$ \\
Tris- $\mathrm{HCl}(\mathrm{pH}=7,9)$ & $10 \mathrm{mM}$ \\
$\mathrm{NaCl}$ & $50 \mathrm{mM}$ \\
$\mathrm{MgCl}_{2}$ & $10 \mathrm{mM}$ \\
$\mathrm{DTT}$ & $1 \mathrm{mM}$ \\
\hline
\end{tabular}

\subsection{Seqüenciamento Direto}

Para o seqüenciamento das amostras foi utilizado o seqüenciador automático. Uma alíquota de $2 \mu$ de cada produto de PCR do exon 4 de $p 53$ foi utilizada para a reação de seqüenciamento do Kit ABI PRISM ${ }^{\mathrm{TM}} 3100$ Byg Dye $^{\mathrm{TM}}$ terminator versão 3.0 Cicle Sequencing Ready Reaction Kit (Perking Elmer, USA). Nesta reação de 
seqüenciamento foi utilizado um dos oligonucleotídeo iniciadores da reação de amplificação do exon 4, p53+ (5' -TCCCCCTTGCCGTCCCCA- 3') na concentração de 5 pmoles $/ \mathrm{ml}$. A reação de seqüenciamento foi realizada num ciclador de temperatura programável do tipo PTC-200 (MJ Research, Massachusetts, USA) em placas de 96 cavidades (Axygen Scientific, Califórnia USA). O perfil de ciclagem contava com um passo inicial de $96^{\circ} \mathrm{C}$ por 90 segundos e 30 ciclos de amplificação $\left(96^{\circ} \mathrm{C}\right.$ por 12 segundos, $55^{\circ} \mathrm{C}$ por 6 segundos e $60^{\circ} \mathrm{C}$ por 4 minutos). Este produto foi precipitado utilizando-se $80 \mu \mathrm{l}$ de isopropanol $75 \%$ seguido de precipitação por 15 minutos no escuro e centrifugação por 45 minutos a $4.000 \mathrm{rpm}$; o sobrenadante foi desprezado e os sedimentos (pellets) lavados com $150 \mu 1$ de etanol $70 \%$ seguidos de centrifugação por 15 minutos da $4.000 \mathrm{rpm}$. Após o descarte do sobrenadante, os pellets secos foram ressuspendindos em $10 \mu \mathrm{l}$ de formamida pura (Applied biosystems, USA) e aquecidos a $95^{\circ} \mathrm{C}$ por 3 minutos. As análises foram feitas através do seqüenciador capilar $\mathrm{ABI}$ PRISM $^{\text {TM }} 3100$ Genetic Analyzer (Applied biosystems, USA).

\subsection{PCR alelo-específica}

Este método foi realizado conforme protocolo padronizado por KAIANO e colaboradores (2000). Os oligonucleotídeos iniciadores específicos para os alelos prolina e arginina foram os mesmos descritos por STOREY e colaboradores (1998). A Figura 8 ilustra a detecção do polimorfismo do códon 72 por este método. 


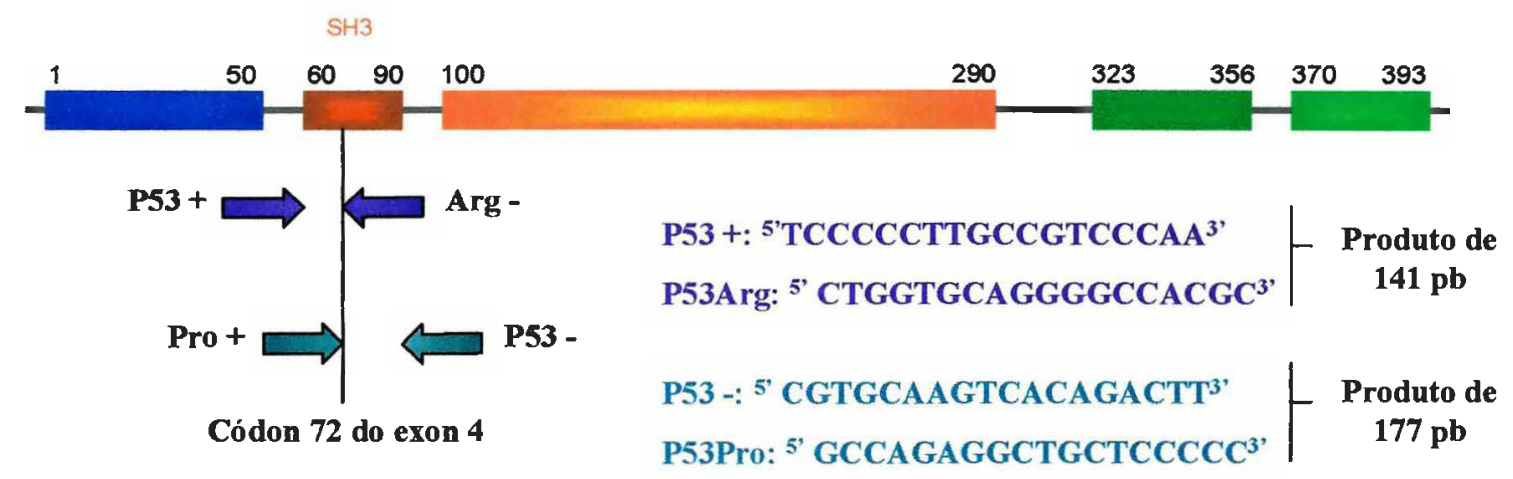

Figura 8. PCR para a deteç̧ão dos alelos de p53. Localização do polimorfismo do códon 72 do exon 4 e as posições dos oligonucleotídeos usados para a detecção do alelo prolina e arginina. Para a amplificação do alelo arginina (p53Arg) são usados os pares de oligonucleotídeos p53+/p53Arg gerando um produto de $141 \mathrm{pb}$. Para a amplificação do alelo prolina (p53Pro) são usados os pares de oligonucleotídeos p53Pro/p53- gerando um produto de $177 \mathrm{pb}$ (Modificado de KAIANO et al., 2000). 
Na reação de PCR foi utilizado: $1 \mu$ de cada oligonucleotídeo p53+ (5' TCCCCCTTGCCGTCCCCA- 3') e p53Arg- (5' -CTGGTGCAGGGGCCACGC- 3') na concentração de 20 pmoles/ $\mu \mathrm{l} ; 1,5 \mathrm{mM}$ de $\mathrm{MgCl}_{2} ; 50 \mathrm{mM} \mathrm{KCl} ; 10 \mathrm{mM}$ TRIS-HCL (pH 8,5); 200 mM de cada dNTP, 2 U de Taq Gold DNA Polimerase (Applied BiosystemsROCHE, New Jersey, USA) e quantidades variáveis de DNA, num volume final de $50 \mu 1$. Esta reação foi especifica para amostras que continham em seu genótipo o alelo p53Arg. Para amplificar amostras contendo em seu genótipo o alelo p53Pro, a reação acima foi realizada com os oligonucleotídeos iniciadores específicos para este alelo: p53- (5' CGTGCAAGTCACAGACTT- 3') e p53Pro+ (5' -GCCAGAGGCTGCTCCCCC- 3').

A reação de PCR para o alelo que codifica para o aminoácido prolina utilizou o seguinte esquema de ciclagem: um passo inicial de $95^{\circ} \mathrm{C}$ por 10 min e 25 ciclos com desnaturação a $94^{\circ} \mathrm{C}$ por 1 min, anelamento a $59^{\circ} \mathrm{C}$ por 1 min e extensão a $72^{\circ} \mathrm{C}$ por 1 min. Foi acrescentado um passo de extensão final de $72^{\circ} \mathrm{C}$ por 7 min. A reação de PCR específica para o alelo que codifica para o aminoácido arginina também foi realizada a partir da ciclagem acima. Entretanto, a temperatura de anelamento utilizada para o par de oligonucleotídeos específicos desta reação, foi $62^{\circ} \mathrm{C}$.

A deteç̧ão deste produto foi feita através de eletroforese em gel de poliacrilamida 8\% seguida de coloração por nitrato de prata (SANGUINETTI et al., 1994).

\subsection{Taqman}

Esta metodologia foi realizada pelos alunos de pós-graduação Anirban Ghosh e Rachel Morse sob a orientação do Dr. Greg Matlashewski do Departamento de Microbiologia da Universidade McGill, Montreal, Quebec, Canadá. 


\section{ANÁLISE ESTATÍSTICA}

As análises estatísticas apresentadas neste trabalho foram realizadas pela aluna de pós-graduação Anita Koushik sob a orientação do Dr. Eduardo L. Franco, diretor da Divisão de Epidemiologia do Departamento de Oncologia da Universidade McGill, Montreal, Quebec, Canadá.

A estratégia utilizada para a escolha das amostras a serem testadas está fundamentada na seleção de uma amostragem caso-controle aninhada (nested casecontrol sampling). Esse sistema de amostragem permite a utilização do cálculo das Razões de Chance (Odds Ratio ou OR) como uma estimativa direta do Risco Relativo (RR). A significância estatística das correlações encontradas e a precisão das estimativas calculadas foram corroboradas pelo cálculo dos intervalos de confiança a 95\% (IC 95\%).

Os cálculos das razões de chances (OR) ajustadas para variáveis cujos efeitos de confusão poderiam influenciar no resultado obtido, tais como raça no caso do polimorfismo do códon 72 , foram também efetuados na tentativa de controlar esses efeitos. Dessa maneira, os dados ajustados serão sempre discriminados ao lado da razão de chance bruta equivalente. A estratégia utilizada para calcular essas estimativas de risco relativo ajustadas foi a regressão logística múltipla incondicional.

Além disso, para avaliar o grau de concordância entre as metodologias, foi

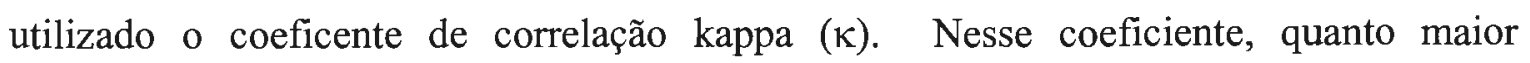
concordância entre as variáveis analisadas, mais próximo da unidade é o valor encontrado. 


\section{RESULTADOS}

\section{PCR PARA O EXON 4 DE $p 53$}

A amplificação do exon 4 de p53 pelo protocolo padronizado por este trabalho produziu um fragmento de 279 pares de base (Figura 9). Do total de 978 amostras selecionadas inicialmente, 960 apresentaram sinais satisfatórios e puderam ser utilizadas em outras metodologias dependentes desta amplificação inicial. Além disso, a regularidade apresentada por este produto fez com que esse protocolo fosse considerado altamente reprodutível.

A utilização de uma PCR do tipo hot start juntamente com um programa de ciclagem conhecido como Touchdown PCR permitiu que inespecificidades e baixo rendimento da reação de PCR fossem contornados. A PCR hot start é recomendada quando é visível a formação de dímeros de iniciadores ou quando amplificações inespecíficas ocorrem. O programa de ciclagem touchdown PCR é recomendado para aumentar o rendimento do produto amplificado, uma vez que as diferentes temperaturas de anelamento utilizadas em ciclos curtos de amplificação facilitam o anelamento de iniciadores com temperaturas de desnaturação variando em mais de $3^{\circ} \mathrm{C}$. No caso dos iniciadores utilizados para amplificar o exon 4 de $p 53$ essa diferença na temperatura de desnaturação era de $6^{\circ} \mathrm{C}$. 


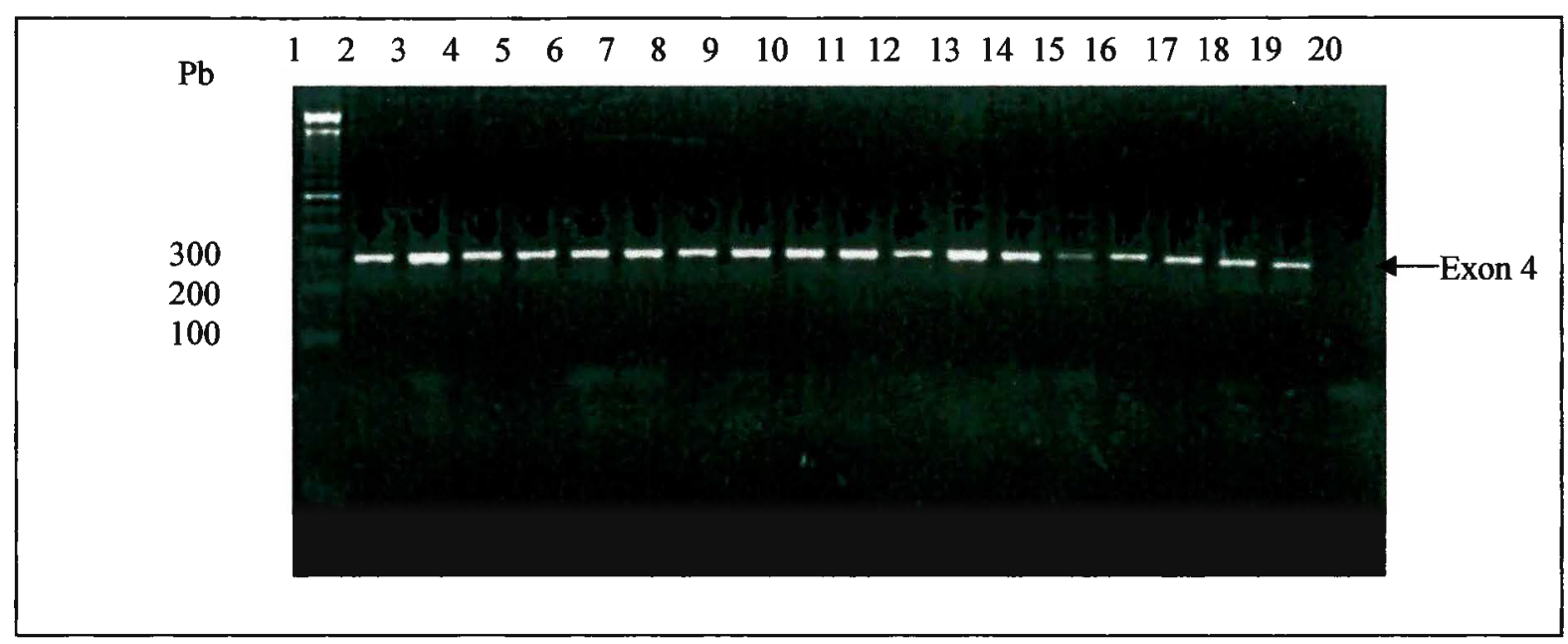

Figura 9. Gel de Agarose 1,5\%, corado por brometo de etídeo, contendo produto de PCR do exon 4 do gene p53 amplificado pelo protocolo padronizado por este projeto. $\mathrm{Na}$ canaleta 1 foi adicionado o marcador de peso molecular (100 bp). Nas canaletas 2 a 19, foram aplicadas testes e na canaleta 20 o controle negativo da reação. 


\section{HIBRIDIZAÇÃO ALELO-ESPECÍFICA}

A padronização desta metodologia permitiu que as 960 amostras amplificadas para o exon 4 de $p 53$ fossem identificadas para o polimorfismo do códon 72 deste gene. A discriminação dos genótipos foi feita através da análise em conjunto das membranas hibridizadas com as sondas específicas para p53Arg e p53Pro. A figura 10 ilustra um autoradiograma obtido através da hibridização com estas sondas e exemplifica o modo de identificação das amostras.

Das 960 amostras amplificadas e submetidas à hibridização aleloespecífica, $41,2 \%$ foram identificadas como heterozigotas para o polimorfismo do códon $72 ; 39,8 \%$ foram identificadas como sendo homozigotas para o alelo p53Arg e 18,9\% foram identificadas como sendo homozigotas para o alelo p53Pro (Figura 11). Esta distribuição está de acordo com o equilíbrio de Hardy-Weinberg esperado. 

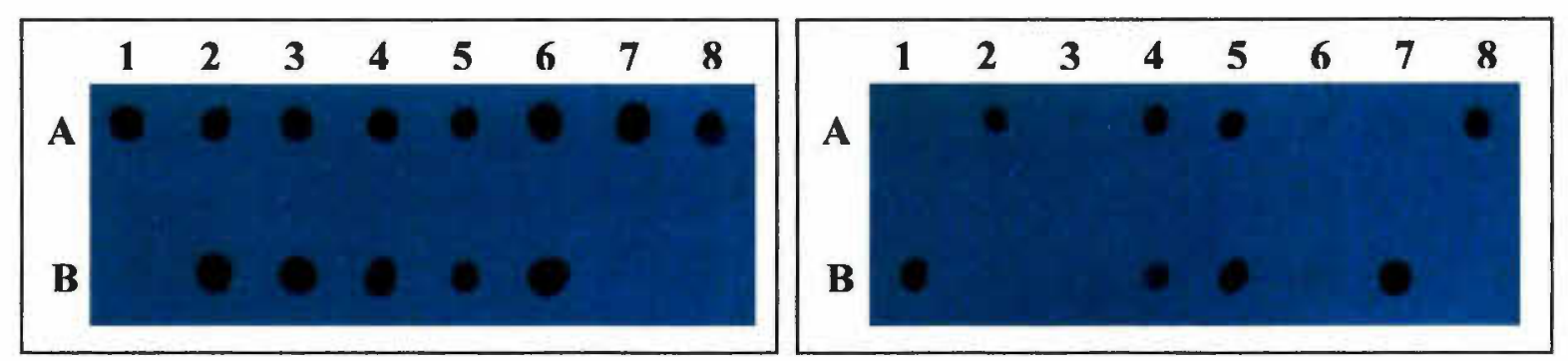

Figura 10. Hibridização alelo-específica das amostras submetidas a amplificação do exon 4 de $p 53$. O quadro a esquerda mostra o autoradiograma de uma membrana hibridizada com a sonda p53Arg. O quadro da direita mostra o autoradiograma de uma membrana hibridizada com a sonda p53Pro. A análise em conjunto dessas membranas ilustra o genótipo das amostras aplicadas. A amostra 1A apresenta um perfil compatível com o de uma amostra homozigota para o alelo p53Arg, uma vez que o sinal só aparece no autoradiograma da membrana hibridizada com a sonda p53Arg. A amostra 2A apresenta padrão característico de uma amostra heterozigota para o polimorfismo do códon 72 , uma vez que apresentou sinal de hibridização em ambas sondas utilizadas. A amostra 1B, por sua vez, apresenta padrão compatível com uma amostra homozigota para o alelo p53Pro, uma vez que o sinal só aparece no autoradiograma da membrana hibridizada com a sonda p53Pro. A amostra B5 representa um controle heterozigoto. A amostra B6 representa um controle homozigoto para o alelo p53Arg. A amostra B7 representa um controle homozigoto para o alelo p53Pro. A amostra B8 representa um controle negativo de amplificação. 


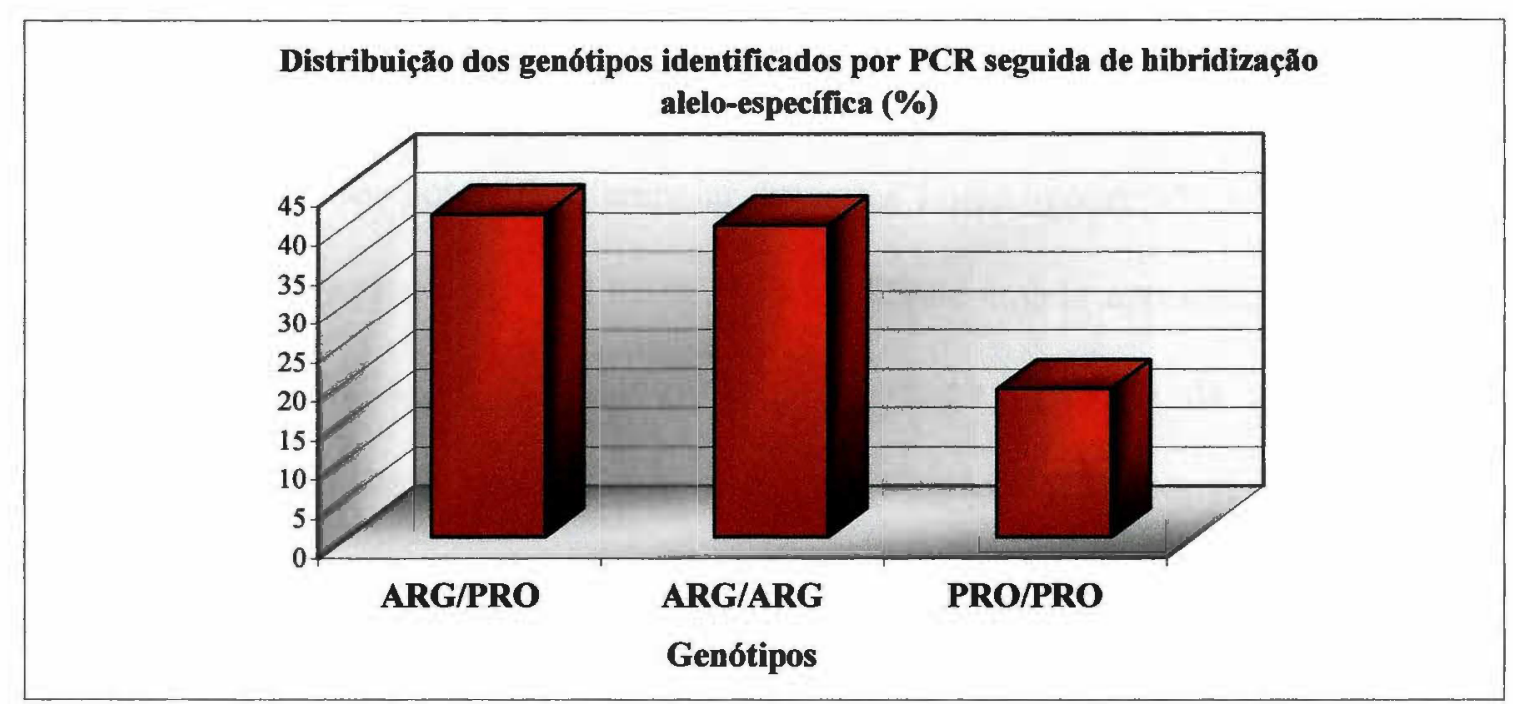

Figura 11. Freqüências genotípicas dos alelos de p53 do códon 72 , em amostras provenientes de esfregaço de colo de útero de uma amostra do estudo epidemiológico prospectivo Ludwig/McGill. Os espécimes heterozigotos representaram $41,2 \%$ do total de amostras submetidas à hibridização alelo-específica. As amostras homozigotas para o alelo arginina representaram $39,8 \%$ e as amostras homozigotas para o alelo prolina $18,9 \%$. 


\section{DHPLC}

As condições ideais de identificação do polimorfismo do códon 72 do gene p53 por esta metodologia foram padronizadas por este trabalho. Quando amostras amplificadas são submetidas à análise por DHPLC o resultado é dado na forma de um cromatograma.

Para o produto do exon 4 de $p 53$ duas triagens foram necessárias. $\mathrm{Na}$ primeira, foi possível diferenciar amostras homozigotas e heterozigotas (Figura 12). Na segunda triagem foi possivel diferenciar amostras homozigotas p53Arg de p53Pro. O cromatograma apresentado nesta etapa era semelhante àquele apresentado pela primeira triagem (Figura 12), ou seja, amostras de genótipo igual ao da amostra controle adicionada nesta etapa apresentaram perfil de eluição único, como aquele visto em amostras homozigotas da primeira triagem. Amostras de genótipo diferente ao da amostra controle adicionada apresentaram perfil de eluição semelhante àquele apresentado por amostras heterozigotas na primeira triagem.

Utilizando essa estratégia foi possível identificar o genótipo do códon 72 de $p 53$ das 960 amostras amplificadas inicialmente. Dessas amostras, 42,2\% foram identificadas como sendo heterozigotas para o polimorfismo do códon $72 ; 40,1 \%$ foram identificadas como sendo homozigotas para o alelo Arg e 17,5\% foram identificadas como sendo homozigotas para o alelo Pro (Figura 13). 


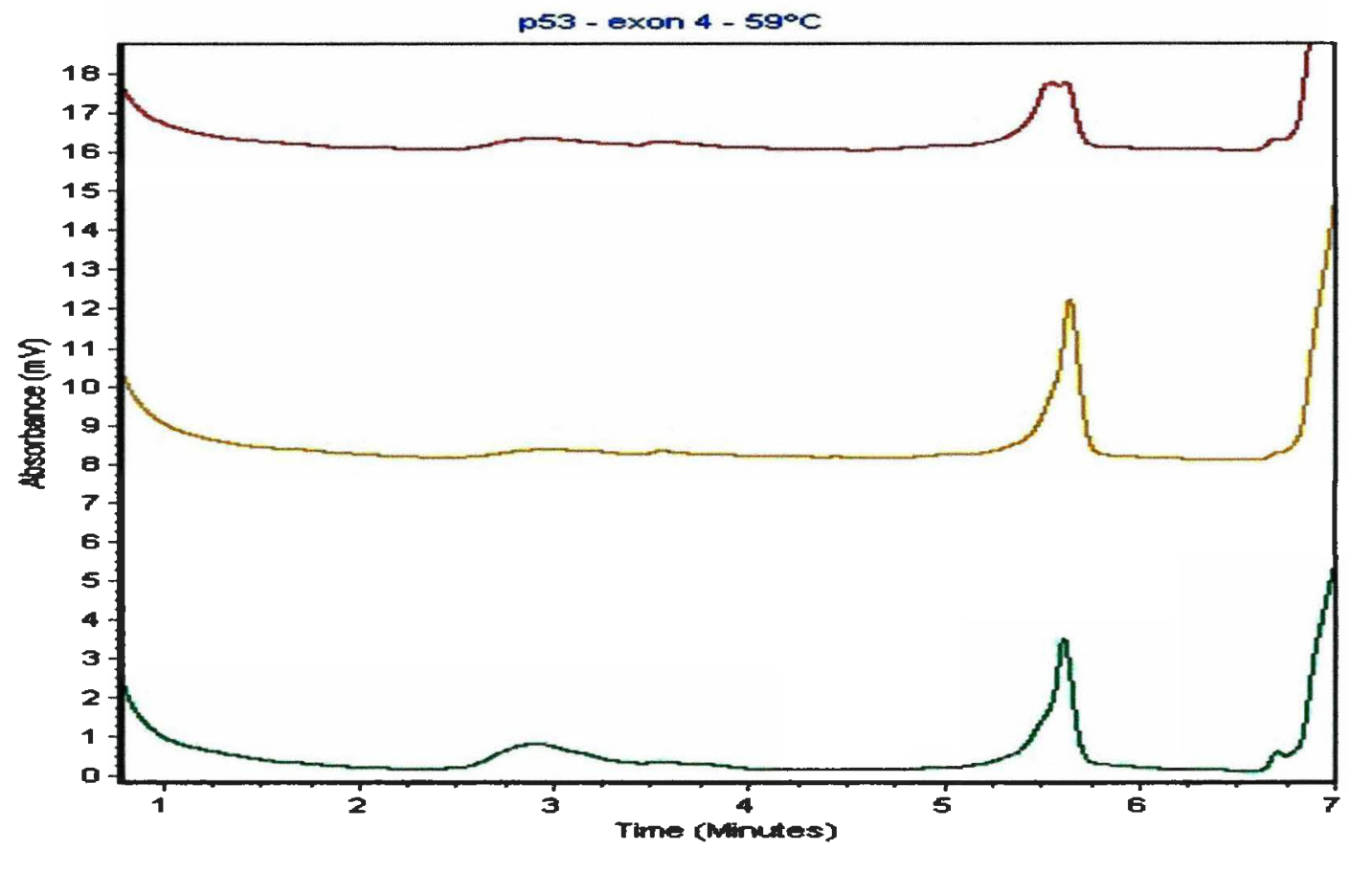

Figura 12. Cromatograma de amostras controles amplificadas e submetidas a primeira triagem por DHPLC. O cromatograma na cor vermelha apresenta o padrão característico de uma amostra heterozigota. Os cromatogramas nas cores amarela e verde apresentam padrão característico de amostras homozigotas. No caso de uma segunda triagem, amostras com genótipo igual ao da amostra controle adicionada neste passo apresentam o perfil cromatográfico visto em amarelo e verde. No caso de uma amostra teste de genótipo diferente ao da amostra controle adicionada neste passo, o perfil cromatográfico é semelhante àquele apresentado em vermelho. 


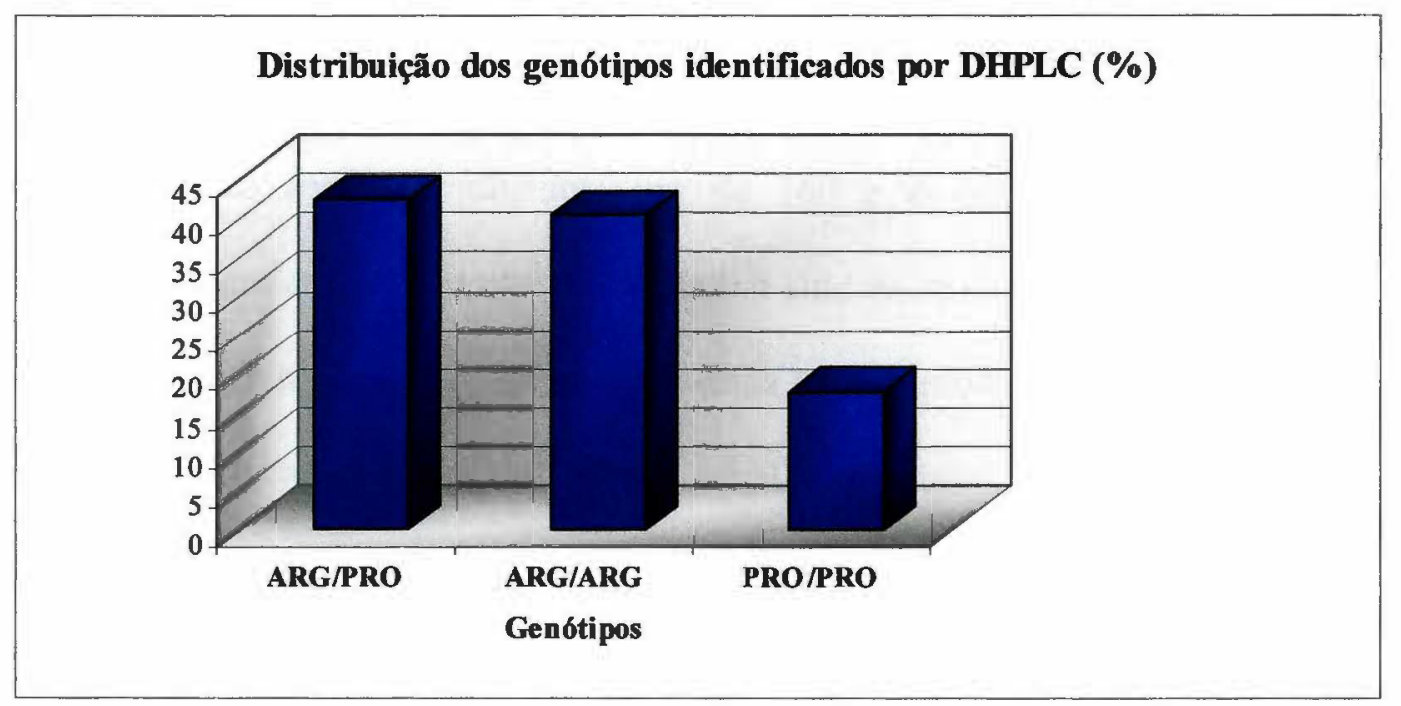

Figura 13. Freqüências genotípicas dos alelos de p53 do códon 72 , em amostras provenientes de esfregaço de colo de útero do estudo epidemiológico prospectivo Ludwig/McGill. As amostras heterozigotas representaram $42,2 \%$ do total de amostras submetidas à hibridização alelo-específica. Quarenta porcento foram homozigotas para o alelo arginina e $17,5 \%$ para o alelo prolina. 


\section{RFLP}

Apesar de muitos trabalhos terem utilizado esta metodologia, algumas modificações tiveram que ser feitas para permitir a adequação desta às condições utilizadas neste projeto. Duas enzimas de restrição foram utilizadas em reações independentes. A enzima BstUI é capaz reconhecer e clivar a seqüência de nucleotídeos que está presente no codon 72 de $p 53$ quando este codifica para o aminoácido arginina. Assim, quando amostras homozigotas para o alelo Arg foram digeridas por esta enzima dois fragmentos foram produzidos: um de 160 e o outro de $119 \mathrm{pb}$. Amostras homozigotas para o alelo Pro não apresentam o sítio de clivagem específico desta enzima e assim não sofrem digestão. O produto desta reação produz um fragmento de $279 \mathrm{pb}$ que corresponde ao produto do exon 4 amplificado inicialmente. Quando amostras heterozigotas foram tratadas com esta enzima, fragmentos de 279,160 e $119 \mathrm{pb}$ puderam ser observados. Estes correspondiam a atividade da enzima em cada um dos alelos componentes de seu genótipo (Figura 14).

A enzima de restrição $B s a$ JI é capaz de reconhecer e clivar a sequência de nucleotídeos que está presente no códon 72 de $p 53$ quando este codifica para o aminoácido prolina. Assim, quando amostras homozigotas para o alelo Pro foram digeridas por esta enzima foram produzidos 5 fragmentos: 94, 66, 44, 41 e $34 \mathrm{pb}$. Amostras homozitotas para o alelo Arg não apresentam um dos sítios de clivagem localizado na trinca de bases correspondentes ao códon 72 de $p 53$. Dessa maneira, essas amostras produzem fragmentos de $138,66,41$ e 34 . Amostras heterozigotas produziam fragmentos correspondentes a somatória dos fragmentos gerados pela digestão de cada um dos alelos por esta enzima (Figura 15). 


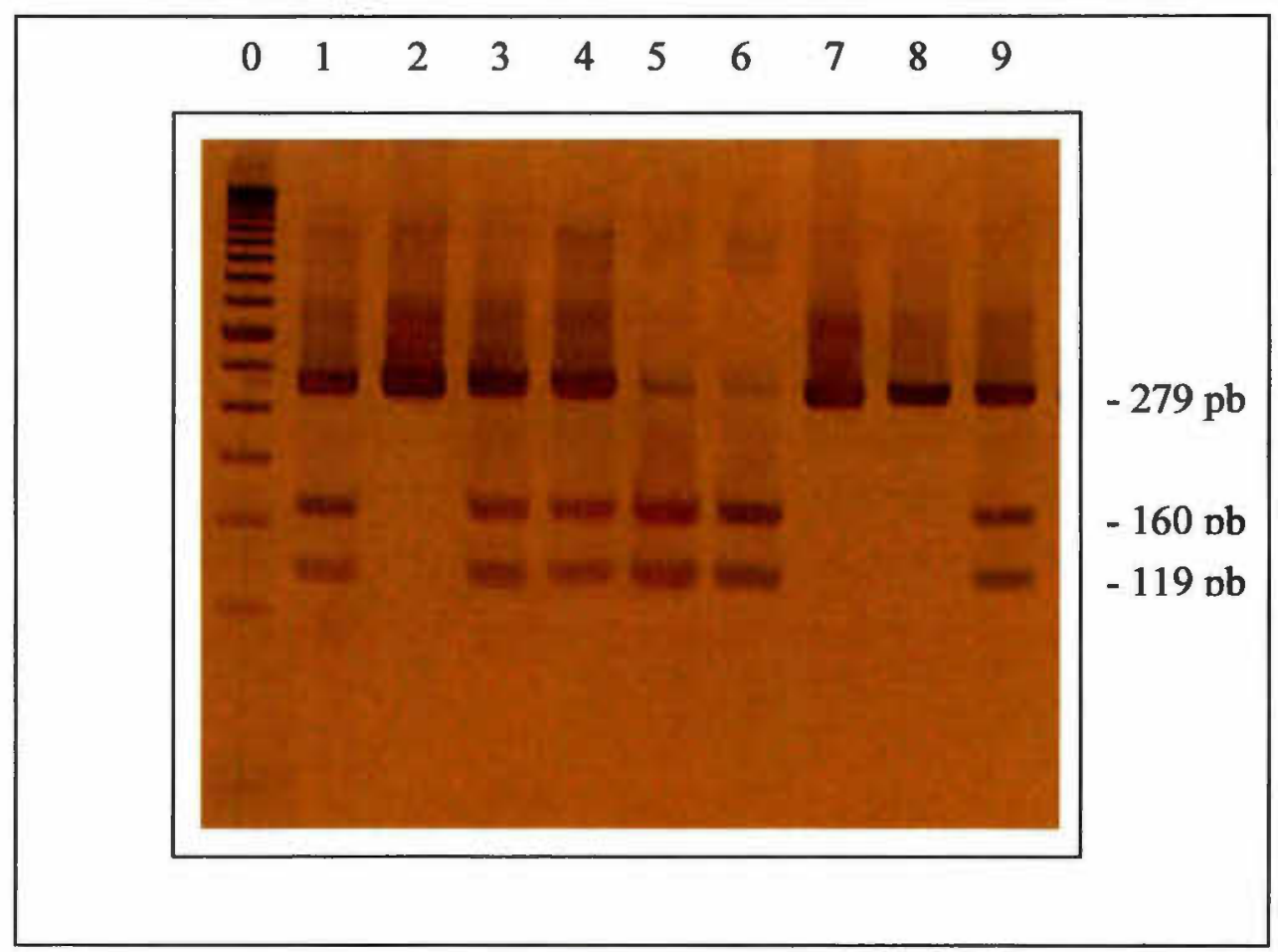

Figura 14. Gel de Poliacrilamida $8 \%$ corado pela prata contendo produtos de PCR do exon 4 do gene p53 digerido pela enzima BstUI. Na canaleta 0 foi adicionado o marcador de peso molecular $(50 \mathrm{pb})$. Nas canaletas $1,3,4$, e 9 amostras identificadas como heterozigotas para o polimorfismo do códon 72 do gene p53. Nas canaletas 2,7 e 8 amostras identificadas como homozigotas prolina e nas canaletas 5 e 6 amostras identificada como sendo homozigotas arginina. 


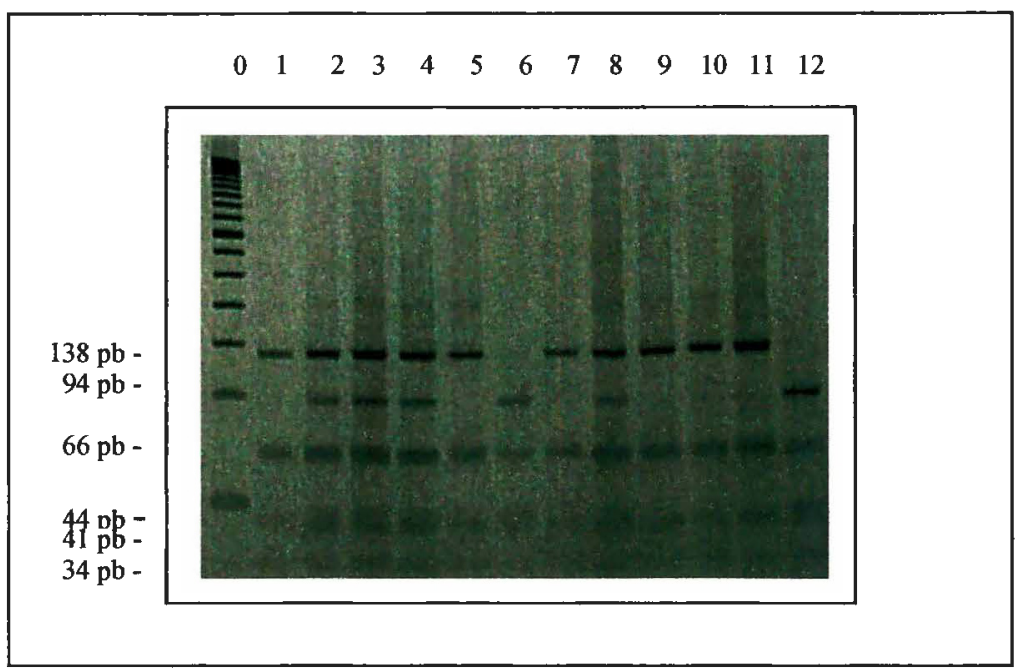

Figura 15. Gel de Poliacrilamida $12 \%$ corado pela prata contendo produto de PCR do exon 4 do gene p53 digerido pela enzima $B s a J I$. Na canaleta 0 foi adicionado o marcador de peso molecular (50 pb). Nas canaletas 2, 3, 4, e 8 amostras identificadas como heterozigotas para o polimorfismo do códon 72 do gene p53. Nas canaletas 6 e 12 amostras identificadas como homozigotas prolina e nas canaletas $1,5,7,9,10$ e 11 amostras identificadas como sendo homozigotas arginina. 
Das 960 amostras submetidas à digestão com a enzima $B s t \mathrm{UI}, 45,3 \%$ foram identificadas como sendo heterozigotas para o polimorfismo do códon $72 ; 34,3 \%$ foram identificadas como sendo homozigotas para o alelo Arg e $20,4 \%$ foram identificadas como sendo homozigotas para o alelo Pro (Figura 16).

Das 960 amostras submetidas à digestão com a enzima $B s a$ I, $43 \%$ foram identificadas como sendo heterozigotas para o polimorfismo do códon $72 ; 40 \%$ foram identificadas como sendo homozigotas para o alelo Arg e 17\% foram identificadas como sendo homozigotas para o alelo Pro (Figura 17).

\section{SEQÜENCIAMENTO DIRETO}

Das amostras amplificadas para o exon 4 de $p 53$, aproximadamente 150 foram selecionadas aleatoriamente e submetidas ao seqüenciamento direto. A figura 18 ilustra o resultado obtido através do seqüenciamento das amostras amplificadas para o exon 4 de $p 53$.

Do total de amostras submetidas a essa metodologia, $42,6 \%$ apresentaramse heterozigotas para o polimorfismo do códon $72 ; 38,7 \%$ apresentaram-se homozigotas para o alelo arginina e $18,7 \%$ apresentaram-se homozigotas para o alelo prolina (Figura 19). 
Distribuição dos genótipos tipados por RFLP utilizando a enzima Bst UI (\%)

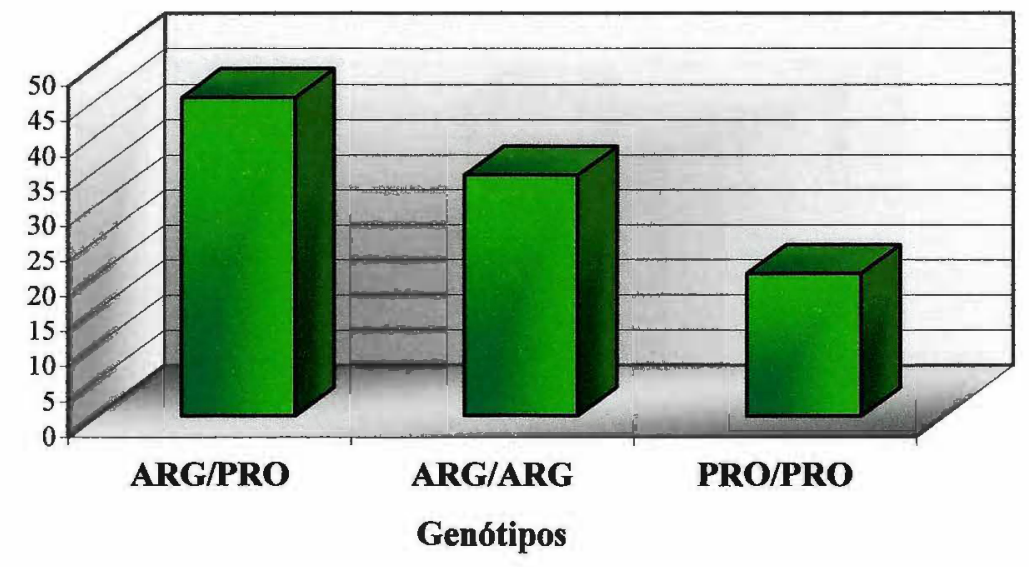

Figura 16. Freqüências genotípicas dos alelos de p53 do códon 72 , em amostras provenientes de esfregaço de colo de útero do estudo epidemiológico prospectivo Ludwig/McGill. As amostras heterozigotas representaram 45,3\% do total de amostras submetidas à hibridização alelo-específica. As amostras homozigotas para o alelo arginina representaram $34,3 \%$ e as amostras homozigotas para o alelo prolina $20,4 \%$. 


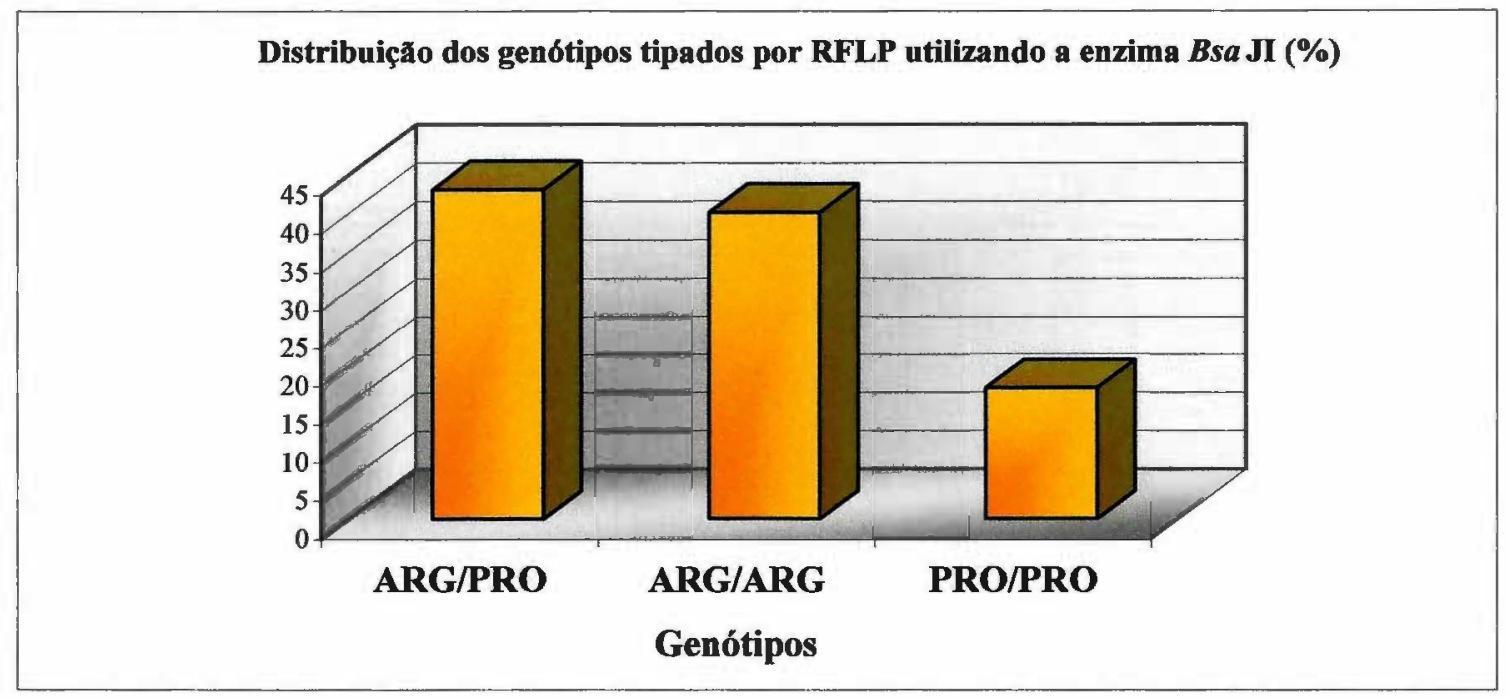

Figura 17. Freqüências genotípicas dos alelos de p53 do códon 72 , em amostras provenientes de esfregaço de colo de útero do estudo epidemiológico prospectivo Ludwig/McGill. As amostras heterozigotas representaram $43 \%$ do total de amostras submetidas à hibridização alelo-específica. As amostras homozigotas para o alelo arginina representaram $40 \%$ e as amostras homozigotas para o alelo prolina $17 \%$. 


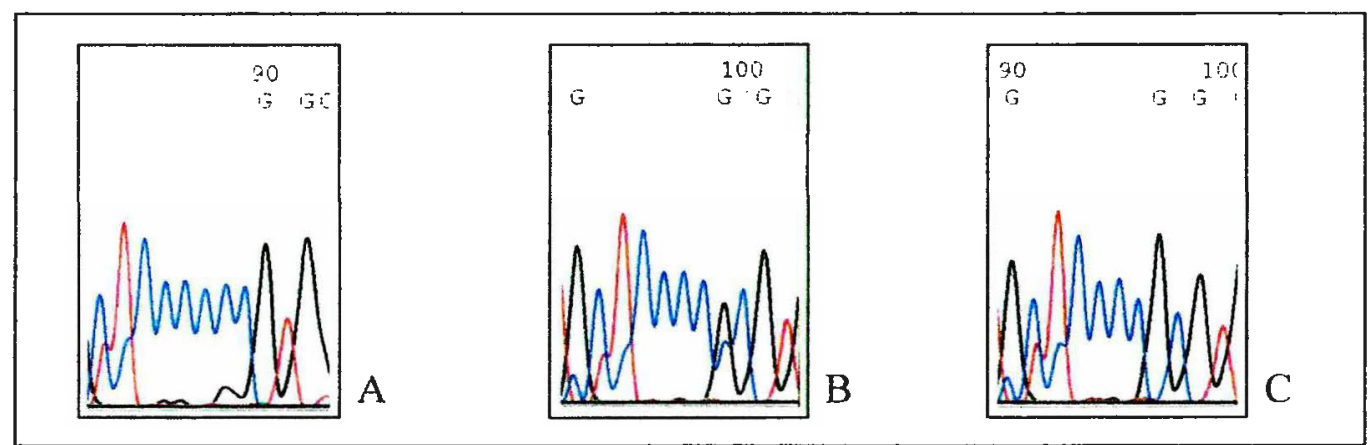

Figura 18. Cromatograma das amostras amplificadas para o exon 4 de $p 53$ submetidas ao seqüienciamento direto. O quadro A ilustra uma amostra homozigota para o alelo prolina, o quadro B ilustra uma amostra heterozitota e o quadro C ilustra uma amostra homozigota para o alelo arginina. 


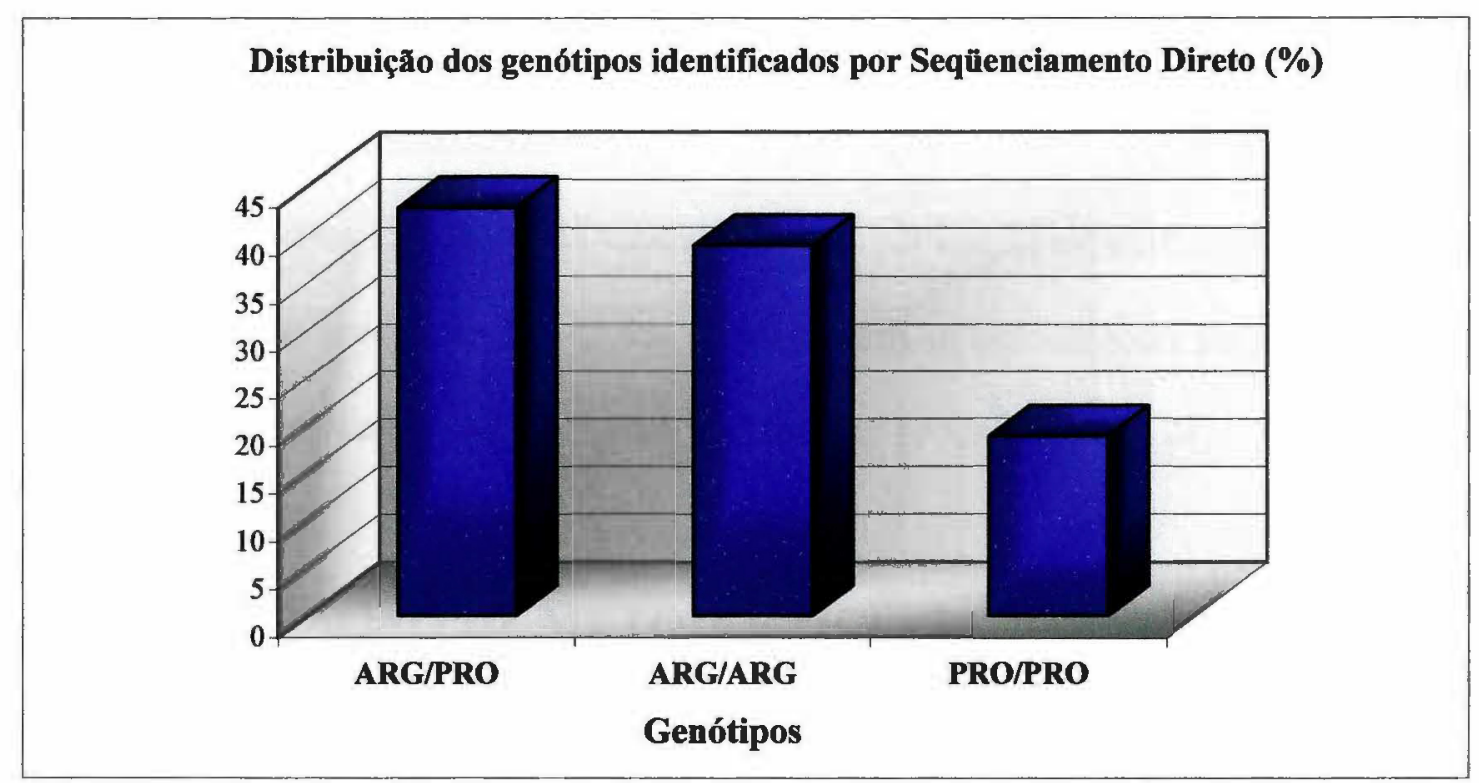

Figura 19. Freqüências genotípicas dos alelos de $p 53$ do códon 72 , em amostras provenientes de esfregaço de colo de útero do estudo epidemiológico prospectivo Ludwig/McGill. As amostras heterozigotas representaram $42,6 \%$ do total de amostras submetidas à hibridização alelo-específica. As amostras homozigotas para o alelo arginina representaram $38,7 \%$ e as amostras homozigotas para o alelo prolina $18,7 \%$. 


\section{PCR ALELO-ESPECÍFICA}

Para identificação do códon 72 de p53 utilizando esta metodologia, 150 amostras foram selecionadas ao acaso. Vale ressaltar que essas amostras não foram as mesmas selecionadas para o seqüenciamento direto. A discriminação dos genótipos foi feita através da análise em conjunto dos géis de poliacrilamida utilizados na eletroforese dessas amostras. A Figura 20 ilustra o resultado obtido e exemplifica o modo de identificação dessas amostras.

Das 150 amostras submetidas a amplificação específica, 34\% das amostras apresentaram-se heterozigotas, $45,4 \%$ apresentaram-se homozigotas para o alelo arginina e 20,6\% apresentaram-se homozigotas para o alelo prolina (Figura 21).

\section{COMPARAÇÃO DE METODOLOGIAS}

Ao todo, sete metodologias de detecção do polimorfismo do códon 72 foram utilizadas. De todas estas, seis (hibridização alelo-específica, DHPLC, RFLP com duas enzimas de restrição em análises independentes, seqüenciamento direto e PCR aleloespecífica) foram realizadas por este trabalho e uma (Taqman) realizada pelo laboratório do Dr. Greg Matlashewski da Universidade McGill.

Todas metodologias, com exceção da PCR alelo-específica, apresentaram distribuições genotípicas semelhante (Tabela 5). A análise de concordância foi realizada entre hibridização alelo-específica, DHPLC e Taqman e o valor de kappa ( $)$ gerado por esta análise utilizado para avaliar o grau de concordância entre estas (Tabela 6). 


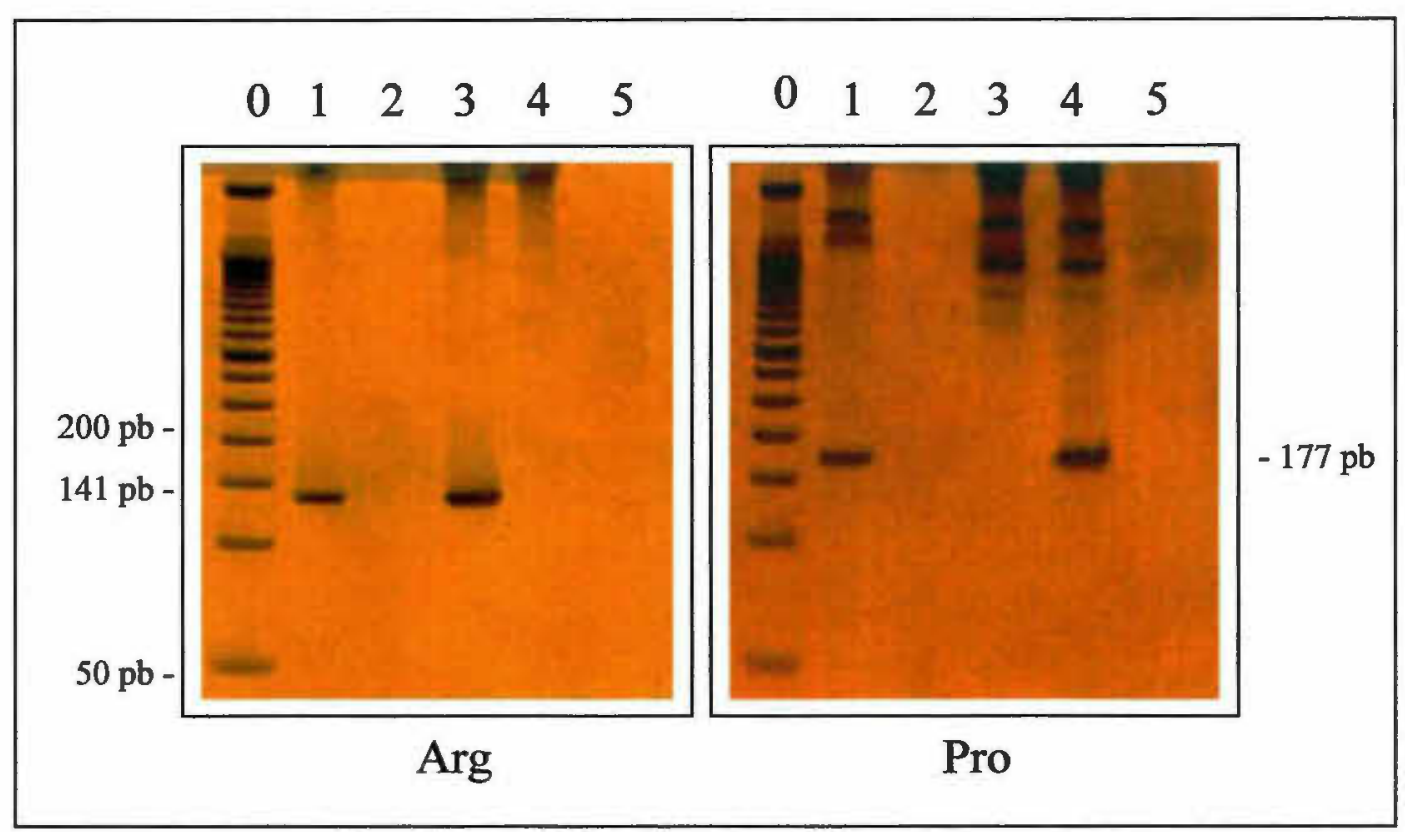

Figura 20. Gel de poliacrilamida $8 \%$ corado pela prata contendo o produto da amplificação específica para o polimorfismo do códon 72 de $p 53$. Na canaleta 0 foi adicionado o marcador de peso molecular $(50 \mathrm{pb})$. $\mathrm{O}$ quadro da esquerda mostra amostras amplificadas com iniciadores específicos para o alelo Arg. O quadro da direita mostra amostras amplificadas com iniciadores específicos para o alelo Pro. A análise em conjunto desses géis ilustra o genótipo das amostras aplicadas. A amostra 1 apresenta perfil compatível com a de uma amostra heterozigota para o polimorfismo do códon 72 , uma vez que apresentou amplificação em ambas reações. A amostra 2 ilustra uma amostra inadequada para amplificação de ambos alelos. A amostra 3 representa uma amostra homozigota para o alelo Arg, uma vez que a amplificação foi específica para o alelo Arg. A amostra 4 representa uma amostra homozigota para o alelo Pro, uma vez que a amplificação foi específica para o alelo Pro. A amostra 5 representa o controle negativo da reação. 


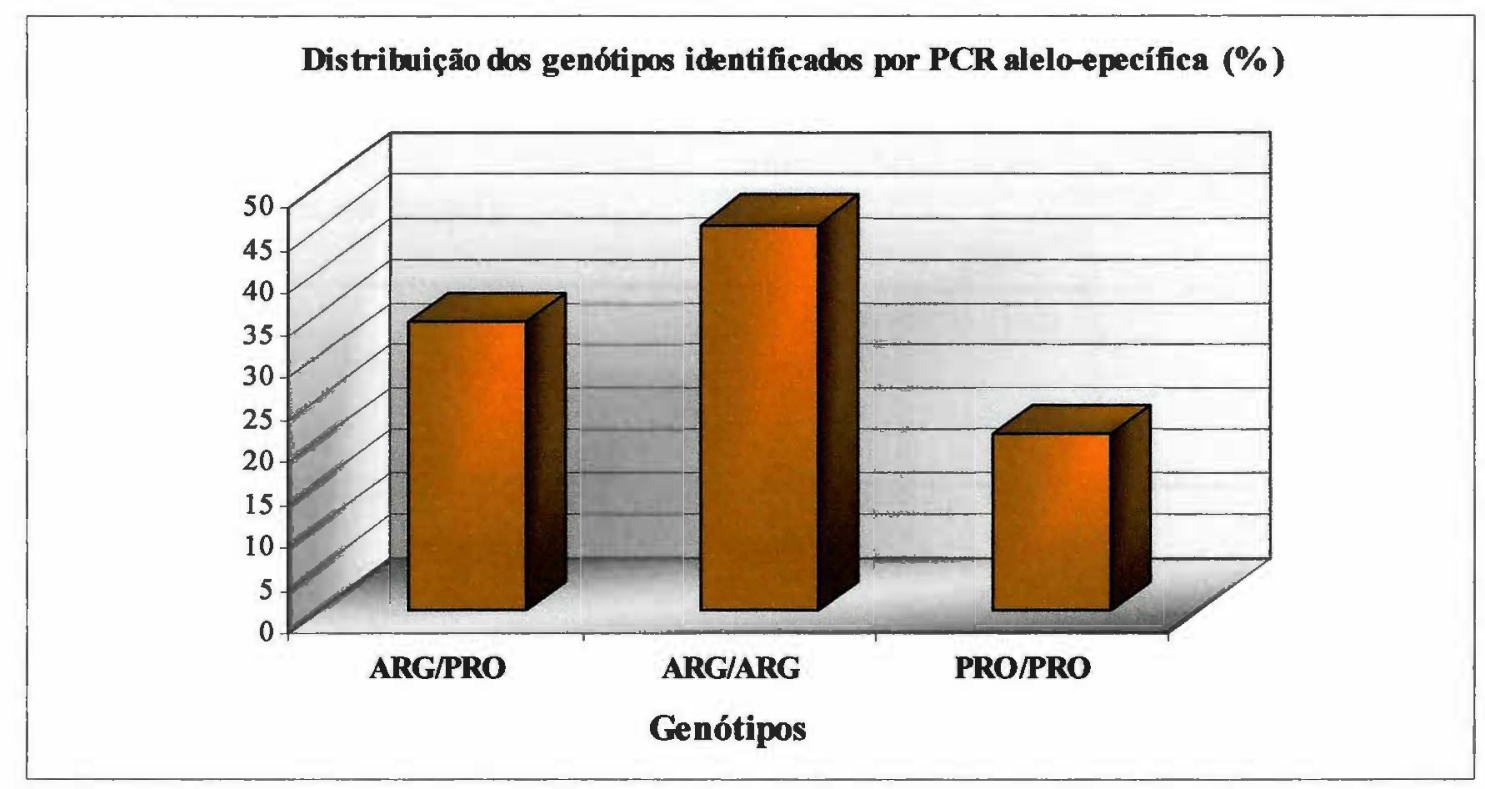

Figura 21. Frequiências genotípicas dos alelos de $p 53$ do códon 72 , em amostras provenientes de esfregaço de colo de útero do estudo epidemiológico prospectivo Ludwig/McGill. As amostras heterozigotas representaram 34\% do total de amostras submetidas à hibridização alelo-específica. As amostras homozigotas para o alelo arginina representaram $45,4 \%$ e as amostras homozigotas para o alelo prolina $20,6 \%$. 
Tabela 5. Freqüência dos genótipos do códon 72 de $p 53$ nas diferentes metodologias.

\begin{tabular}{lccc}
\hline \multirow{2}{*}{ MÉTODO DE IDENTIFICAÇÃO } & \multicolumn{3}{c}{ FREQÜÊENCIA DOS GENÓTIPOS (\%) } \\
\cline { 2 - 4 } & Arg/Arg & Arg/Pro & Pro/Pro \\
\hline Hibridização alelo-específica $(\mathrm{n}=960)$ & 39,8 & 41,2 & 18,9 \\
DHPLC (n=960) & 40,1 & 42,2 & 17,5 \\
Taqman (n=789) & 37,6 & 47,7 & 14,7 \\
RFLP-BstUI (n=960) & 34,3 & 45,3 & 20,4 \\
RFLP-BsaJI (n=960) & 40,0 & 43,0 & 17,0 \\
Seqüenciamento Direto ( $\mathrm{n}=150)$ & 38,7 & 42,6 & 18,7 \\
PCR alelo-específica (n=150) & 45,4 & 34,0 & 20,6 \\
\hline
\end{tabular}

Tabela 6. Análise de concordância ${ }^{1}$ entre hibridização alelo-específica, DHPLC e Taqman (valores de kappa).

\begin{tabular}{lcc}
\hline & Hibridização alelo-específica & DHPLC \\
\hline Hibridização alelo-específica & & \\
DHPLC & 0,94 & \\
Taqman & 0,88 & 0,86 \\
\hline 1. Apenas amostras que apresentaram resultados disponiveis nas trés metodologias utilizadas.
\end{tabular}

\section{CORRELAÇÃO ENTRE O POLIMORFISMO DO CÓDON 72 DE p53, HPV E LESÕES PRECURSORAS DO CARCINOMA DO COLO UTERINO.}

Para avaliar se o polimorfísmo do códon 72 poderia estar associado com o risco de infecções por HPV e lesões precursoras do carcinoma do colo uterino foram utilizados, até o momento, dados gerados por três diferentes metodologias: Hibridização alelo-específica, DHPLC e Taqman. Os resultados obtidos a partir de cada técnica foram analisados individualmente e as amostras que apresentaram resultados concordantes foram agrupadas numa nova categoria. Amostras homozigotas para prolina e heterozigotas foram agrupadas e consideradas categoria de referência. 
Quando o polimorfismo do códon 72 foi correlacionado com positividade para HPV de baixo e alto risco nenhuma associação foi observada (Tabelas 7 e 8).

Tabela 7. OR da associação entre o genótipo de p53 e qualquer infecção com HPV de baixo risco oncogênico nas diferentes metodologias utilizadas e na sua concordância.

\begin{tabular}{|c|c|c|c|c|}
\hline $\begin{array}{c}\text { Genótipo de } p 53 \text { nas } \\
\text { diferentes metodologias }\end{array}$ & Negativa, $\mathbf{N}$ & Baixo Risco, N & OR (IC 95\%) & $\begin{array}{c}\text { OR ajustada para raça } \\
\text { (IC } 95 \%)\end{array}$ \\
\hline \multicolumn{5}{|l|}{ Hibridização alelo-específica } \\
\hline Arg/Pro or Pro/Pro & 338 & 70 & 1.00 (referência) & 1.00 (referência) \\
\hline Arg/Arg & 226 & 33 & $0.71(0.45-1.10)$ & $0.75(0.48-1.19)$ \\
\hline \multicolumn{5}{|l|}{ DHPLC } \\
\hline Arg/Pro or Pro/Pro & 333 & 69 & 1.00 (referência) & 1.00 (referência) \\
\hline Arg/Arg & 231 & 34 & $0.71(0.46-1.11)$ & $0.76(0.48-1.20)$ \\
\hline \multicolumn{5}{|l|}{$\operatorname{Taqman}^{\circ}$} \\
\hline Arg/Pro or Pro/Pro & 341 & 68 & 1.00 (referência) & 1.00 (referência) \\
\hline Arg/Arg & 223 & 35 & $0.79(0.51-1.22)$ & $0.84(0.54-1.32)$ \\
\hline \multicolumn{5}{|l|}{ Concordância ${ }^{2}$} \\
\hline Arg/Pro or Pro/Pro & 298 & 60 & 1.00 (referência) & 1.00 (referência) \\
\hline Arg/Arg & 213 & 30 & $0.70(0.44-1.12)$ & $0.75(0.46-1.21)$ \\
\hline
\end{tabular}

1. Metodologia realizada pelo laboratório do Dr. Greg Matlashewski

2. Resultados que apresentaram o mesmo genótipo nas três diferentes metodologias

Tabela 8. OR da associação entre o genótipo de p53 e qualquer infecção com HPV de alto risco oncogênico nas diferentes metodologias utilizadas e na sua concordância.

\begin{tabular}{|c|c|c|c|c|}
\hline $\begin{array}{c}\text { Genótipo de } p 53 \text { nas } \\
\text { diferentes metodologias }\end{array}$ & Negativa, $\mathbf{N}$ & Alto Risco, $\mathbf{N}$ & OR (IC 95\%) & $\begin{array}{c}\text { OR ajustada para raça } \\
(\text { IC 95\%) }\end{array}$ \\
\hline \multicolumn{5}{|l|}{ Hibridização alelo-específica } \\
\hline Arg/Pro or Pro/Pro & 338 & 74 & 1.00 (referência) & 1.00 (referência) \\
\hline Arg/Arg & 226 & 48 & $0.97(0.65-1.45)$ & $1.03(0.69-1.55)$ \\
\hline \multicolumn{5}{|l|}{ DHPLC } \\
\hline Arg/Pro or Pro/Pro & 333 & 73 & 1.00 (referência) & 1.00 (referência) \\
\hline Arg/Arg & 231 & 49 & $0.97(0.65-1.44)$ & $1.03(0.68-1.54)$ \\
\hline \multicolumn{5}{|l|}{ Taqman $^{1}$} \\
\hline Arg/Pro or Pro/Pro & 341 & 83 & 1.00 (referência) & 1.00 (referência) \\
\hline Arg/Arg & 223 & 39 & $0.72(0.47-1.09)$ & $0.76(0.50-1.16)$ \\
\hline \multicolumn{5}{|l|}{ Concordância $^{2}$} \\
\hline Arg/Pro or Pro/Pro & 298 & 66 & 1.00 (referência) & 1.00 (referência) \\
\hline $\mathrm{Arg} / \mathrm{Arg}$ & 213 & 36 & $0.76(0.49-1.19)$ & $0.78(0.5-1.23)$ \\
\hline
\end{tabular}

1. Metodologia realizada pelo laboratório do Dr. Greg Matlashewski

2. Resultados que apresentaram o mesmo genótipo nas três diferentes metodologias 
Da mesma forma, quando o polimorfismo do códon 72 foi correlacionado com infecções persistentes por HPV de baixo e alto risco, nenhuma associação pode ser observada (Tabelas 9 e 10). Entretanto, quando essa análise foi restrita para HPV-16 uma OR de 7,86 foi encontrada, embora não sendo significativa, como mostra o intervalo de confiança incluindo a unidade $(\mathrm{IC}=0,75-82,13)($ Tabela 11$)$.

Tabela 9. OR das associações entre o genótipo de $p 53$ e infecções ${ }^{1}$ persistentes $^{2}$ para HPV de baixo risco oncogênico nas diferentes metodologias utilizadas e na sua concordância.

\begin{tabular}{|c|c|c|c|c|}
\hline $\begin{array}{l}\text { Genótipo de } p 53 \text { nas diferentes } \\
\text { metodologias }\end{array}$ & $\begin{array}{c}\text { Infecção } \\
\text { Transiente, } \mathrm{N}\end{array}$ & $\begin{array}{c}\text { Infeç̧ão } \\
\text { Persistente } \\
\text { baixo risco, N }\end{array}$ & OR (IC 95\%) & $\begin{array}{l}\text { OR ajustada para raça } \\
\text { (IC 95\%) }\end{array}$ \\
\hline \multicolumn{5}{|l|}{ Hibridização alelo-específica } \\
\hline Arg/Pro or Pro/Pro & 69 & 35 & 1.00 (referência) & 1.00 (referência) \\
\hline Arg/Arg & 48 & 13 & $0.53(0.26-1.11)$ & $0.53(0.25-1.10)$ \\
\hline \multicolumn{5}{|l|}{ DHPLC } \\
\hline Arg/Pro or Pro/Pro & 68 & 35 & 1.00 (referência) & 1.00 (referência) \\
\hline Arg/Arg & 49 & 13 & $0.52(0.25-1.07)$ & $0.51(0.25-1.07)$ \\
\hline \multicolumn{5}{|l|}{ Taqman $^{3}$} \\
\hline Arg/Pro or Pro/Pro & 77 & 33 & 1.00 (referência) & 1.00 (referência) \\
\hline Arg/Arg & 40 & 15 & $0.88(0.43-1.80)$ & $0.86(0.42-1.77)$ \\
\hline \multicolumn{5}{|l|}{ Concordância $^{4}$} \\
\hline Arg/Pro or Pro/Pro & 59 & 32 & 1.00 (referência) & 1.00 (referência) \\
\hline Arg/Arg & 37 & 12 & $0.60(0.27-1.31)$ & $0.60(0.27-1.30)$ \\
\hline
\end{tabular}

1. Exclusão de infecções persistentes por HPV de alto risco

2. Duas ou mais visitas positivas para o mesmo tipo de HPV durante o primeiro ano

3. Metodologia realizada pelo laboratório do Dr. Greg Matlashewski

4. Resultados que apresentaram o mesmo genótipo nas três diferentes metodologias 
Tabela 10. OR das associações entre o genótipo de $p 53$ e infecções ${ }^{1}$ persistentes ${ }^{2}$ para HPV de alto risco oncogênico nas diferentes metodologias utilizadas e na sua concordância.

\begin{tabular}{|c|c|c|c|c|}
\hline $\begin{array}{l}\text { Genótipo de p53 nas diferentes } \\
\text { metodologias }\end{array}$ & $\begin{array}{c}\text { Infecção } \\
\text { Transiente, } \mathbf{N}\end{array}$ & $\begin{array}{c}\text { Infecção } \\
\text { Persistente } \\
\text { alto risco, } \mathbf{N} \\
\end{array}$ & OR (IC 95\%) & $\begin{array}{c}\text { OR ajustada para raça } \\
\text { (IC 95\%) }\end{array}$ \\
\hline \multicolumn{5}{|l|}{ Hibridização alelo específica } \\
\hline Arg/Pro or Pro/Pro & 69 & 40 & 1.00 (referência) & 1.00 (referência) \\
\hline Arg/Arg & 48 & 20 & $0.72(0.37-1.38)$ & $0.70(0.36-1.35)$ \\
\hline \multicolumn{5}{|l|}{ DHPLC } \\
\hline Arg/Pro or Pro/Pro & 68 & 39 & 1.00 (referência) & 1.00 (referência) \\
\hline Arg/Arg & 49 & 21 & $0.75(0.39-1.42)$ & $0.74(0.38-1.41)$ \\
\hline \multicolumn{5}{|l|}{ Taqman $^{3}$} \\
\hline Arg/Pro or Pro/Pro & 77 & 41 & 1.00 (referência) & 1.00 (referência) \\
\hline Arg/Arg & 40 & 19 & $0.89(0.46-1.73)$ & $0.83(0.42-1.64)$ \\
\hline \multicolumn{5}{|l|}{ Concordância ${ }^{4}$} \\
\hline Arg/Pro or Pro/Pro & 59 & 35 & 1.00 (referência) & 1.00 (referência) \\
\hline Arg/Arg & 37 & 17 & $0.77(0.38-1.58)$ & $0.75(0.37-1.54)$ \\
\hline
\end{tabular}

Tabela 11. OR das associações entre o genótipo de $p 53$ e infecções ${ }^{1}$ persistentes ${ }^{2}$ para HPV-16 nas diferentes metodologias utilizadas e na sua concordância.

\begin{tabular}{|c|c|c|c|c|}
\hline $\begin{array}{c}\text { Genótipo de } p 53 \text { nas diferentes } \\
\text { metodologias }\end{array}$ & $\begin{array}{c}\text { Infecção } \\
\text { Transiente, } \mathbf{N}\end{array}$ & $\begin{array}{c}\text { Infecção } \\
\text { Persistente } \\
\text { HPV-16, N }\end{array}$ & OR (IC 95\%) & $\begin{array}{c}\text { OR ajustada para raça } \\
\text { (IC 95\%) }\end{array}$ \\
\hline \multicolumn{5}{|l|}{ Hibridização alelo-específica } \\
\hline Arg/Pro or Pro/Pro & 12 & 10 & 1.00 (referência) & 1.00 (referência) \\
\hline Arg/Arg & 2 & 5 & $3.00(0.48-18.93)$ & $3.16(0.49-20.43)$ \\
\hline \multicolumn{5}{|l|}{ DHPLC } \\
\hline Arg/Pro or Pro/Pro & 12 & 9 & 1.00 (referência) & 1.00 (referência) \\
\hline Arg/Arg & 2 & 6 & $4.00(0.65-24.66)$ & $4.55(0.70-29.75)$ \\
\hline \multicolumn{5}{|l|}{ Taqman $^{3}$} \\
\hline Arg/Pro or Pro/Pro & 13 & 9 & 1.00 (referência) & 1.00 (referência) \\
\hline Arg/Arg & 1 & 6 & $8.67(0.89-84.84)$ & $8.45(0.86-83.10)$ \\
\hline \multicolumn{5}{|l|}{ Concordância ${ }^{4}$} \\
\hline Arg/Pro or Pro/Pro & 11 & 7 & 1.00 (referência) & 1.00 (referência) \\
\hline $\mathrm{Arg} / \mathrm{Arg}$ & 1 & 5 & $7.86(0.75-82.13)$ & $7.86(0.75-82.13)$ \\
\hline
\end{tabular}


Numa segunda análise, a categoria persistência foi dividida em duas outras: persistência de curta duração, definida por duas visitas positivas para o mesmo tipo de HPV no decorrer do primeiro ano e persistência de longa duração, definida por três ou mais visitas positivas para o mesmo tipo de HPV no decorrer do primeiro ano. Nesta etapa, pode ser observado que o polimorfismo do códon 72 de p53 não apresentou nenhuma associação com infecções persistentes tanto de curta duração (Tabela 12) quanto de longa duração por HPV-16 e 18 (Tabela 13).

Tabela 12. OR das associações entre o genótipo de $p 53$ e infecções ${ }^{1}$ persistentes de curta duração $^{2}$ para HPV-16 e HPV-18 nas diferentes metodologias utilizadas e na sua concordância.

\begin{tabular}{|c|c|c|c|c|}
\hline $\begin{array}{c}\text { Genótipo de p } 53 \text { nas diferentes } \\
\text { metodologias }\end{array}$ & $\begin{array}{c}\text { Infeç̧ão } \\
\text { Transiente, } \mathbf{N}\end{array}$ & $\begin{array}{c}\text { Infecção } \\
\text { Persistente, } \mathbf{N} \\
\end{array}$ & OR (IC 95\%) & $\begin{array}{c}\text { OR ajustada para raça } \\
\text { (IC 95\%) }\end{array}$ \\
\hline \multicolumn{5}{|l|}{ Hibridização alelo-específica } \\
\hline Arg/Pro or Pro/Pro & 13 & 6 & 1.00 (referência) & 1.00 (referência) \\
\hline Arg/Arg & 6 & 1 & $0.36(0.04-3.70)$ & $0.29(0.03-3.21)$ \\
\hline \multicolumn{5}{|l|}{ DHPLC } \\
\hline Arg/Pro or Pro/Pro & 13 & 5 & 1.00 (referência) & 1.00 (referência) \\
\hline Arg/Arg & 6 & 2 & $0.87(0.13-5.82)$ & $0.82(0.12-5.66)$ \\
\hline \multicolumn{5}{|l|}{ Taqman $^{3}$} \\
\hline Arg/Pro or Pro/Pro & 15 & 5 & 1.00 (referência) & 1.00 (referência) \\
\hline Arg/Arg & 4 & 2 & $1.50(0.21-10.82)$ & $1.19(0.15-9.36)$ \\
\hline \multicolumn{5}{|l|}{ Concordância ${ }^{4}$} \\
\hline Arg/Pro or Pro/Pro & 12 & 4 & 1.00 (referência) & 1.00 (referência) \\
\hline Arg/Arg & 4 & 1 & $0.75(0.06-8.83)$ & $0.57(0.05-7.33)$ \\
\hline
\end{tabular}


Tabela 13. OR das associações entre o genótipo de $p 53$ e infecções ${ }^{1}$ persistentes de longa duração $^{2}$ para HPV-16 e HPV-18 nas diferentes metodologias utilizadas e na sua concordância.

\begin{tabular}{|c|c|c|c|c|}
\hline $\begin{array}{l}\text { Genótipo de } p 53 \text { nas diferentes } \\
\text { metodologias }\end{array}$ & $\begin{array}{c}\text { Infecção } \\
\text { Transiente, } \mathbf{N}\end{array}$ & $\begin{array}{c}\text { Infeç̧ão } \\
\text { Persistente, } \mathbf{N}\end{array}$ & OR (IC 95\%) & $\begin{array}{l}\text { OR ajustada para raça } \\
\text { (IC } 95 \%)\end{array}$ \\
\hline \multicolumn{5}{|l|}{ Hibridizacão alelo-específica } \\
\hline Arg/Pro or Pro/Pro & 13 & 6 & 1.00 (referência) & 1.00 (referência) \\
\hline Arg/Arg & 6 & 4 & $1.44(0.29-7.10)$ & $1.47(0.30-7.35)$ \\
\hline \multicolumn{5}{|l|}{ DHPLC } \\
\hline Arg/Pro or Pro/Pro & 13 & 6 & 1.00 (referência) & 1.00 (referência) \\
\hline Arg/Arg & 6 & 4 & $1.44(0.29-7.10)$ & $1.47(0.30-7.35)$ \\
\hline \multicolumn{5}{|l|}{$\operatorname{Taqman}^{3}$} \\
\hline Arg/Pro or Pro/Pro & 15 & 6 & 1.00 (referência) & 1.00 (referência) \\
\hline Arg/Arg & 4 & 4 & $2.50(0.47-13.39)$ & $2.60(0.47-14.26)$ \\
\hline \multicolumn{5}{|l|}{ Concordância ${ }^{4}$} \\
\hline Arg/Pro or Pro/Pro & 12 & 5 & 1.00 (referência) & 1.00 (referência) \\
\hline Arg/Arg & 4 & 4 & $2.40(0.42-13.60)$ & $2.71(0.45-16.38)$ \\
\hline \multicolumn{5}{|c|}{ 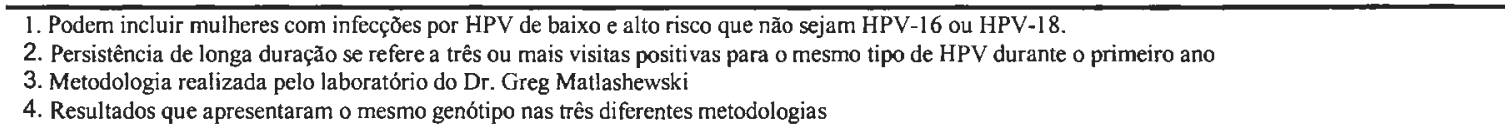 } \\
\hline \multicolumn{5}{|c|}{ O próximo passo foi averiguar se o risco de lesão intraepitelial escamosa } \\
\hline \multicolumn{5}{|c|}{ de baixo grau (LSIL) estaria associado ao polimorfismo do códon 72 de $p 53$. Na tabela } \\
\hline \multicolumn{5}{|c|}{14 observa-se que não há nenhuma associação significativa. $\mathrm{O}$ mesmo foi observado } \\
\hline
\end{tabular}


Tabela 14. OR das associações entre o genótipo de $p 53$ e LSIL $^{1}$ nas diferentes metodologias utilizadas e na sua concordância.

\begin{tabular}{|c|c|c|c|c|}
\hline $\begin{array}{c}\text { Genótipo de } p 53 \text { nas diferentes } \\
\text { metodologias }\end{array}$ & Normal, $\mathbf{N}$ & LSIL, N & OR (IC 95\%) & $\begin{array}{c}\text { OR ajustada para raça } \\
\text { (IC 95\%) }\end{array}$ \\
\hline \multicolumn{5}{|l|}{ Hibridização alelo-específica } \\
\hline Arg/Pro or Pro/Pro & 413 & 30 & 1.00 (referência) & 1.00 (referência) \\
\hline Arg/Arg & 250 & 19 & $1.05(0.58-1.90)$ & $1.08(0.59-1.99)$ \\
\hline \multicolumn{5}{|l|}{ DHPLC } \\
\hline Arg/Pro or Pro/Pro & 406 & 32 & 1.00 (referência) & 1.00 (referência) \\
\hline Arg/Arg & 257 & 17 & $0.84(0.46-1.54)$ & $0.83(0.46-1.51)$ \\
\hline \multicolumn{5}{|l|}{$\operatorname{Taqman}^{2}$} \\
\hline Arg/Pro or Pro/Pro & 417 & 32 & 1.00 (referência) & 1.00 (referência) \\
\hline Arg/Arg & 246 & 17 & $0.90(0.49-1.66)$ & $0.93(0.50-1.73)$ \\
\hline \multicolumn{5}{|l|}{ Concordância ${ }^{3}$} \\
\hline Arg/Pro or Pro/Pro & 364 & 26 & 1.00 (referência) & 1.00 (referência) \\
\hline Arg/Arg & 232 & 13 & $0.78(0.40-1.56)$ & $0.83(0.42-1.67)$ \\
\hline
\end{tabular}

Tabela 15. OR das associações entre o genótipo de p53 e $\mathrm{HSIL}^{1}$ nas diferentes metodologias utilizadas e na sua concordância.

\begin{tabular}{|c|c|c|c|c|}
\hline $\begin{array}{l}\text { Genótipo de p53 nas diferentes } \\
\text { metodologias }\end{array}$ & Normal, $\mathbf{N}$ & HSIL, $\mathbf{N}$ & OR (IC 95\%) & $\begin{array}{l}\text { OR ajustada para raça } \\
\text { (IC 95\%) }\end{array}$ \\
\hline \multicolumn{5}{|l|}{ Hibridização alelo-específica } \\
\hline Arg/Pro or Pro/Pro & 413 & 8 & 1.00 (referência) & 1.00 (referência) \\
\hline Arg/Arg & 250 & 7 & $1.45(0.52-4.03)$ & $1.51(0.53-4.27)$ \\
\hline \multicolumn{5}{|l|}{ DHPLC } \\
\hline Arg/Pro or Pro/Pro & 406 & 7 & 1.00 (referência) & 1.00 (referência) \\
\hline Arg/Arg & 257 & 8 & $1.81(0.65-5.04)$ & $1.89(0.67-5.36)$ \\
\hline \multicolumn{5}{|l|}{$\operatorname{Taqman}^{2}$} \\
\hline Arg/Pro or Pro/Pro & 417 & 10 & 1.00 (referência) & 1.00 (referência) \\
\hline Arg/Arg & 246 & 5 & $0.85(0.29-2.51)$ & $0.87(0.29-2.63)$ \\
\hline \multicolumn{5}{|l|}{ Concordância ${ }^{3}$} \\
\hline Arg/Pro or Pro/Pro & 364 & 7 & 1.00 (referência) & 1.00 (referência) \\
\hline Arg/Arg & 232 & 5 & $1.12(0.35-3.57)$ & $1.11(0.34-3.62)$ \\
\hline
\end{tabular}




\section{DISCUSSÃO}

A primeira evidência de que o polimorfismo do códon 72 poderia estar associado a maior risco de desenvolvimento de neoplasias surgiu em 1992 quando WESTON e colaboradores evidenciaram uma maior prevalência de genótipo homozigoto prolina em portadores de câncer de pulmão. Outros estudos subseqüentes também evidenciaram uma forte associação entre este genótipo e o carcinoma nasofaríngeo (BIRGANDER et al., 1996) e uma fraca associação entre este e o câncer de mama (SJANDLER et al., 1996; WESTON et al., 1997). Observações com relação ao genótipo arginina evidenciaram, por sua vez, que este estava fortemente associado ao câncer de ovário (BULLER et al., 1997).

Foi somente em 1998 que surgiu a primeira evidencia de associação entre o polimorfismo do códon 72 de p53 e o carcinoma do colo uterino. Neste estudo STOREY e colaboradores apresentaram resultados de que o genótipo homozigoto arginina estava sete vezes mais representado entre mulheres com carcinoma do colo uterino do que no grupo controle. Este trabalho serviu de base para muitos estudos posteriores que não evidenciaram a mesma associação. Entretanto, o fato de alguns trabalhos ainda corroborarem os achados de STOREY, faz com que a associação seja alvo de grande controvérsia na literatura.

Um dos motivos que poderiam levar a resultados tão discordantes foram investigados por MAKNI e colaboradores (2000). Neste estudo, observamos que o efeito da variação interlaboratorial poderia subestimar a associação entre o polimorfismo do códon 72 de $p 53$ e o carcinoma do colo uterino. Neste trabalho, três laboratórios 
diferentes identificaram o polimorfismo do códon 72 de amostras de uma população de baixa renda do nordeste do Brasil utilizando PCR alelo-específica. Os resultados mostraram grande variação na proporção dos genótipos de p53 identificados nos diferentes laboratórios com um coeficiente de concordância $\kappa$ variando de $0,49-0,63$. A não exclusão das amostras discordantes da análise resultou em uma OR de associação entre o polimorfismo do códon 72 e o carcinoma uterino de $1,5(95 \%$ IC=0,5-3,9). Entretanto, a exclusão da análise de resultados discordantes elevou a OR desta associação de 1,5 para 8,0 e trouxe o intervalo de confiança de $95 \%$ para a faixa estatisticamente significativa (2,3-28,5). A restrição das análises às amostras controle positivas para HPV aumentou significativamente a magnitude desta relação $(\mathrm{OR}=21,5 ; 95 \%$ IC=3,4-137,8) enquanto que se os resultados discordantes fossem incluídos na análise a magnitude desta diminuía significativamente $(\mathrm{OR}=2,9 ; 95 \% \mathrm{IC}=0,7-11,9)$.

A partir deste trabalho foi possível evidenciar que a ocorrência de erros na classificação das amostras poderia subestimar a associação entre o polimorfismo do códon 72 do gene $p 53$ e o carcinoma do colo uterino. Este fato induziu ao questionamento de quanto desta variabilidade poderia ser atribuída às variações entre metodologias. Logo, o objetivo deste trabalho foi avaliar o impacto da utilização de diferentes metodologias de detecção do polimorfismo do códon 72 na ocorrência de erros classificatório e conseqüentemente na correlação entre este polimorfismo e o desenvolvimento de lesões precursoras e ao carcinoma do colo uterino.

Para obtenção dos resultados, este trabalho analisou amostras de pacientes pertencentes ao estudo epidemiológico prospectivo Ludwig/McGill onde 2.500 mulheres estão sendo acompanhadas por 5 anos visando descrever a história natural das infecções 
pelo HPV e o risco de neoplasia cervical . Essas amostras foram previamente testadas para presença do DNA de HPV e avaliadas por citologia oncótica. O polimorfísmo do códon 72 foi identificado por sete diferentes metodologias: hibridização alelo-específica, DHPLC, RFLP utilizando duas enzimas de restrição em análises independentes, seqüenciamento direto, PCR alelo-específica e Taqman, sendo esta última realizada pelo laboratório do Dr. Greg Matlashewski.

De todas metodologias utilizadas, apenas a PCR alelo-específica apresentou freqüência genotípica diferente das observadas em outros métodos (34\% de heterozigotas, $45,4 \%$ de homozigotas para arginina e $20,6 \%$ homozigotas para prolina). Coincidentemente, esta foi a mesma metodologia utilizada para avaliar a variação interlaboratorial no trabalho de MAKNI e colaboradores (2000). Esta técnica está baseada na detecção genotípica do polimorfismo do códon 72 através da amplificação diferencial dos alelos deste gene. Nesta amplificação diferencial dois fragmentos diferentes são formados: um de $141 \mathrm{pb}$, específico para amplificação do alelo que codifica para o aminoácido arginina e outro de 177 pb, específico para amplificação do alelo que codifica para o aminoácido prolina. Uma das hipóteses propostas pelo trabalho de MAKNI e colaboradores (2000) é a de que fragmentos de menor tamanho apresentariam vantagem de amplificação em amostras cujo DNA apresentasse baixa qualidade. Isso poderia provocar a diminuição de amplificação do alelo p53Pro e conseqüentemente, elevação do alelo p53Arg. Essa amplificação diferencial poderia provocar um decréscimo na deteç̧ão das amostras heterozigotas ocasionando assim um acréscimo no número de amostras homozigotas arginina. Entretanto, essa hipótese é apontada por esses autores como mera especulação. Isso porque fragmentos menores de 
200 pb são normalmente bem amplificados independentemente da qualidade do DNA. Além disso, a pequena diferença de tamanho entre os fragmentos que identificam os genótipos de $p 53$ não deveria ser suficiente para promover essa amplificação diferencial. Da mesma forma, o DNA dos espécimes cervicais utilizados por este trabalho não se encaixa no perfil apresentado uma vez que os DNA utilizados são de alta qualidade.

O resultado observado através do uso desta metodologia poderia nos dar indícios da influência dos erros classificatórios na associação do polimorfismo do códon 72 de $p 53$ com o carcinoma cervical. Isso porque não só o trabalho de STOREY e colaboradores (1998) mas muitos outros (AGORASTOS et al., 2000; BAEK et al., 2000; BASTIENS et al., 2001; BERTORELLE et al., 1999; DYBIKOWSKA et al., 2000; GIANNOUDIS et al. 1999; KIM et al., 2001; LANHAM et al., 1998; MADELEINE et al., 2000; MALCOLM et al., 2000; MINAGUCHI et al., 1998; NGAN et al., 1999; NGAN et al., 2000; NISHIKAWA et al., 2000; PEGORARO, et al., 2000; PEGORARO, et al., 2002; ROSENTHAL et al., 1998; SARANATH et al., 2002; SKARKA, et al., 1999; SKARKA, et al., 2000; TACHEZY et al., 1999; TENTI et al., 2000; VAN DUIN et al., 2000; YAMASHITA et al., 1999) utilizaram esta metodologia para deteç̧ão do polimorfismo do códon 72 de $p 53$. Vale ressaltar que a possível ocorrência de erros classificatórios não estaria favorecendo um ou outro resultado de associação. De fato, estes trabalhos apresentam associações tanto positivas quanto negativas entre o genótipo arginina e neoplasia do colo uterino.

É interessante ressaltar que os dados observados por todos os trabalhos que apresentaram associação positiva foram obtidos através de PCR alelo-específica (AGORASTOS et al., 2000; DOKIANAKIS et al., 2000; MAKNI et al., 2000; 
PEGORARO et al., 2002; SARANATH et al., 2002; STOREY et al., 1998; VAN DUIN et al., 2000) ou SSCP (Single Strand Conformational Polymorphism) (ANDERSSON et al., 2002; ZEHBE et al., 1999; ZEHBE et al., 2001). Interessantemente, a eficiência de detecção de SSCP vem sendo contestada por trabalhos que compararam os resultados obtidos por esta metodologia com àqueles obtidos por DHPLC (CARGILL et al., $1999 \mathrm{e}$ O’DONOVAN et al., 1998). Dessa maneira, foi possível concluir que a PCR aleloespecífica poderia, eventualmente, levar a resultados equivocados.

A identificação do polimorfismo do códon 72 de p53 por DHPLC realizada por este trabalho apresentou resultados bem semelhantes aos obtidos por outras duas outras metodologias testadas: hibridização alelo-específica e Taqman. Os valores de coeficiente $\kappa$ obtidos através do cálculo de correlação entre estas metodologias foram consideravelmente altos indicando grande concordância entre estes métodos. Dessa maneira, o resultado individual de cada uma destas metodologias foi utilizado para avaliar a magnitude da associação entre o polimorfismo do códon 72 de p53 com variáveis de risco para infecções por HPV e lesões precursoras do carcinoma do colo uterino. Apesar da alta concordância entre estas metodologias, se fez necessário a criação de uma outra categoria de análise onde todos os resultados discordantes apresentados pelas três metodologias foram excluídos.

A partir destas análises foi possível evidenciar a falta de associação entre o polimorfismo do códon 72 de p53 e a positividade para HPV de baixo e alto risco (Tabelas 7 e 8). As diferentes metodologias não apresentaram qualquer variação significativa nas OR apresentadas, nem mesmo quando estas foram ajustadas para raça. Esse ajuste é importante uma vez que a distribuição racial do polimorfismo de $p 53$ é 
sabidamente diferente. Sabe-se que o genótipo homozigoto prolina é muito mais comum em populações negróides, o mesmo sendo observado para o genótipo homozigoto arginina em populações caucasóides. Vale ressaltar que a população brasileira é altamente miscigenada.

O fato dos HPV de alto risco apresentarem valores de OR semelhante àqueles observados pelos HPV de baixo risco sugere que as associações eventualmente encontradas entre mulheres portadoras de lesão não deveriam ser atribuídas à positividade do HPV.

A infecção persistente por tipos oncogênicos de HPV é considerada um dos principais fatores de risco para o desenvolvimento de lesões do colo uterino (HO et al., 1995; SCHLECHT et al., 2001). Essa infecção é caracterizada por dois resultados positivos para o mesmo tipo viral em duas ou mais visitas no decorrer do primeiro ano de seguimento do estudo. Ao avaliar se o polimorfismo do códon 72 de $p 53$ poderia estar associado com infecções persistentes por HPV de baixo e alto risco nenhuma associação estatisticamente significativa foi observada (Tabelas 10 e 11). Diferenças entre metodologias não estavam relacionadas à falta desta associação uma vez que as OR apresentadas nestas análises foram bem semelhantes. $\mathrm{O}$ ajuste realizado também evidenciou que esse resultado não poderia ser atribuído à distribuição racial apresentada pelo polimorfismo do códon 72 de p53. Esses dados em conjunto sugerem que este polimorfismo não estaria influenciando diretamente a persistência de HPV seja este de alto ou baixo risco. Entretanto, devido à heterogeneidade desses grupos, associações específicas para alguns tipos de HPV poderiam ser ocultadas. Apesar disso, uma análise específica para cada categoria individual (tipo de HPV) poderia promover grande 
flutuação estatística, uma vez que esta poderia apresentar número reduzido de amostras. Isso de fato pode ser observado quando apenas infecções persistentes por HPV-16 foram correlacionadas com o polimorfismo do códon 72 de p53 (Tabela 11). O pequeno número de amostras apresentados nesta análise fez com que as associações observadas diferissem não somente com relação ao observado para infecção persistente por HPV de alto risco, mas também nas diferentes metodologias utilizadas para detecção do polimorfismo do códon 72. A magnitude da associação (OR) ajustada por raça observada entre este polimorfismo e o risco de infecções persistentes por HPV-16 nas diferentes metodologias variou de 3,16 (95\% IC=0,49-20,43) a 8,45 (95\% IC=0,70-29,75). Além disso, a grande amplitude do intervalo de confiança, aliada ao fato deste incluir a unidade, fez com que estes dados fossem considerados possíveis eventos de flutuação estatística.

Numa segunda análise, a categoria persistência foi dividida em duas outras: persistência de curta duração, definida por duas visitas positivas para o mesmo tipo de HPV no decorrer do primeiro ano e persistência de longa duração, definida por três ou mais visitas positivas para o mesmo tipo de HPV no decorrer do primeiro ano. A correlação entre o polimorfismo do códon 72 e infecção persistente de curta duração por HPV-16 e 18 (Tabela 12) mostrou que essa variável não parece ser influenciada pelo genótipo apresentado pelo códon 72 deste gene. Pode ser observado também que, devido ao pequeno número de amostras disponíveis para esta análise, as diferentes metodologias apresentaram resultados ligeiramente diferentes. Ainda assim, nenhuma significância estatística foi observada uma vez que todos intervalos de confiança incluíram a unidade. A persistência de longa duração também apresentou resultados semelhantes com um 
ligeiro acréscimo na magnitude das associações observadas. Entretanto, o pequeno número de amostras já observado em outras categorias, fez com que essa análise fosse considerada pouco representativa.

Ao averiguar se o polimorfismo do códon 72 estaria correlacionado ao risco de desenvolvimento de lesões precursoras do carcinoma do colo, nenhuma associação foi observada (Tabelas 14 e 15). As diferentes metodologias também não apresentaram variações relevantes. O fato dos dados terem sido ajustados por raça não modificou a magnitude das associações observadas sem esta correção. Aparentemente, o fator racial não estaria influenciando as análises como possível fator de confusão.

De uma maneira geral, os dados apresentados por este trabalho corroboram os achados de tantos outros autores (BAEK et al., 2000; BASTIENS et al., 2001; BERTORELLE et al., 1999; CALHOUN et al., 2002; DYBIKOWSKA et al., 2000; GIANNOUDIS et al. 1999; GUSTAFSSON et al., 2001; HAYES et al., 1998; HELLAND et al., 1998; HILDESHEIM et al., 1998; JOSEFSSON et al., 1998; KIM et al., 2001; KLAES et al., 1999; KUCERA, et al., 2000; LANHAM et al., 1998; MADELEINE et al., 2000; MALCOLM et al., 2000; MINAGUCHI et al., 1998; NGAN et al., 1999; NGAN et al., 2000; NISHIKAWA et al., 2000; PEGORARO, et al., 2000; REZZA et al., 2001; ROSENTHAL et al., 1998; SKARKA, et al., 1999; SONODA et al., 1999; SUAREZ-RINCON et al., 2002; TACHEZY et al., 1999; TENTI et al., 2000; TONG et al., 1999; WANG et al., 1999; WONG et al., 2000; YAMASHITA et al., 1999). Entretanto, este trabalho é o primeiro a avaliar prospectivamente se infecções persistentes por HPV e as lesões precursoras do carcinoma do colo uterino (LSIL e HSIL) estariam correlacionadas ao genótipo encontrado no polimorfismo do códon 72 de $p 53$. 
Vale ressaltar, ainda, que apesar do pequeno número de amostras, o polimorfismo do códon 72 de p53 está associado à infecções persistentes por HPV-16 indicando assim um possível papel deste na persistência desta infecção.

Os dados obtidos pelo uso de diferentes metodologias poderiam nos dar indícios de que resultados de associações positivas entre o genótipo do códon 72 e o risco de neoplasia do colo uterino apresentassem influência da relativa eficiência de detecção da PCR alelo-específica e de SSCP. Entretanto, os dados apresentados por MAKNI e colaboradores (2000) observaram associação positiva deste polimorfismo com o risco de carcinoma do colo uterino mesmo excluindo da análise os resultados discordantes apresentados pelos três laboratórios onde o polimorfismo foi identificado a partir de PCR alelo-específica.

Dessa maneira, não é possível afirmar que a controvérsia observada na literatura seria devida ao uso de diferentes metodologias de detecção. O motivo que leva a ocorrência de resultados tão discordantes ainda permanece obscuro. Além disso, não podemos concluir que tais discrepâncias se devam à forma de análise dos resultados, onde as categorias homozigoto prolina e heterozigotas são combinadas como categoria de referência, já que o risco fora originalmente atribuído ao homozigoto arginina.

Estudos funcionais são igualmente exíguos e não permitem concluir o papel do polimorfismo do códon 72 de $p 53$ no desenvolvimento de lesões precursoras do carcinoma do colo uterino in vivo. 


\section{CONCLUSÕES}

- Houve elevada concordância entre todos os métodos testados, com exceção da PCR alelo-específica.

- Mulheres portadoras do genótipo homozigoto arginina apresentaram maior risco de infecção persistente por HPV-16, embora esta associação não seja significativa.

- Infecções persistentes por HPV de alto risco e lesões precursoras do carcinoma do colo uterino (LSIL e HSIL) aparentemente não estariam correlacionados ao genótipo encontrado no polimorfismo do códon 72 de $p 53$.

- O impacto causado pelo uso de diferentes metodologias de detecção não é suficiente para explicar os resultados controversos de associações entre o polimorfismo do códon 72 do gene $p 53$ e risco de neoplasia da cérvice uterina. 


\section{REFERÊNCIAS BIBLIOGRÁFICAS}

AGORASTOS, T.; LAMBROPOULOS, A. F.; CONSTANTINIDIS, T. C.; KOTSIS, A.; BONTIS, J. N. p53 codon 72 polymorphism and risk of intra-epithelial and invasive cervical neoplasia in Greek woman. Eur. J. Cancer Prev., v. 9, p. 113-118, 2000.

ANDERSSONS, S.; RYLANDER, E.; STRAND, A.; SALLSTROM, J.; WILANDER, E. The significance of $\mathrm{p} 53$ codon 72 polymorphism for the development of cervical adenocarcinomas. Br. J. Cancer, Vol. 19, p. 1153-1156, 2001.

APPLE, R.J.; ERLICH, H.Á.; KLITZ, W.; MANOS, M.M.; BECKER, T.M.; WHEELER, C.M. HLA DR-DQ associations with cervical carcinoma show papillomavirus-type specificity. Nature Genet., Vol. 6, p. 157-162, 1994.

ARENDS, M.J.; WYLLIE, A.H.; BIRD, C.C.; Papillomavirus and human cancer. Hum Pathol., Vol. 21, p. 686-698, 1990.

BAEK, W.K.; CHO, J.W.; SUH, S.I.; SUH, M.H.; SHIN, D.H.; CHO, C.H.; LEE, T.S.; CHA, S.D. p53 codon 72 polymorphism and risk of cervical carcinoma in Korean women. J. Korean Med. Sci., Vol. 1, p. 65-67, 2000.

BALINT, E.E.; VOUSDEN, K.H. Activation and activities of the p53 tumor suppressor protein. Br. J. Cancer, Vol 85, p. 1813-1823, 2001.

BARBOSA, M.S.; SCHLEGEL, R. The E6 and E7 genes of HPV-18 are sufficient for inducing two-stage in vitro transformation of human keratinocytes. Oncogene, Vol. 4, p. 1529-1532, 1989.

BASTIAENS, M.T.; STRUYK, L.; TJONG-A-HUNG, S.P.; GRUIS, N.; TER HUURNE, J.; WESTENDORP, R.G.; VERMEER, B.J.; BAVINCK, J.N.; TER SCHEGGET, J. Cutaneous squamous cell carcinoma and p53 codon 72 polymorphism: a need for screening ?. Mol. Carcinog., Vol 30, p. 56-61, 2001. 
BAUER, H.M.; HILDESHEIM, A.; SCHIFFMAN, M.H.; GLASS, A.G.; RUSH, B.B.; SCOTT, D.R.; CADELL, D.M.; KURMAN, R.J.; MANOS, M.M. Determinants of genital human papillomavirus infection in low-risk women in Portland Oregon. Sex Transm. Dis., Vol. 20, p. 274-278, 1993.

BECKMAN, G.; BIRGANDER, R. SJALANDER, A.; SAHA, N.; HOLMBERG, P.; KIVELD, S.; BECKMAN, L. Is p53 polymorphism maintained by natural selection? Hum. Hered., v. 44, p. 266-270, 1994.

BEDELL, M.A.; JONES, K.H.; GROSSMAN, S.R.; LAIMINS, L. A. Identification of human papillomavirus type 18 transforming genes in immortalized and primary cells. $\mathbf{J}$. Virol., Vol. 63, p. 1247-1255, 1989.

BEER-ROMERO, P.; GLASS, S.; ROLFE, M. Antisense targeting of E6AP elevates p53 in HPV-infected cells but not in normal cells. Oncogene, v. 14, p. 595-602, 1997.

BERNARD, H.U.; CHAN, S.Y.; MANOS, M.M.; ONG, C.K.; VILLA, L.L.; DELIUS, H.; PEYTON, C.L.; BAUER, H.M.; WHEELER, C.M. Identification and assessment of known and novel human papillomaviruses by polymerase chain reaction amplification, restriction fragment length polymorphisms, nucleotide sequence, and phylogenetic algorithms. J. Infect. Dis., v. 170, p. 1077-85, 1994.

BERTORELLE, R.; CHIECO-BIANCHI, L.; DEL MISTRO, A. Papillomavirus and p53 codon 72 polymorphism. Int. J. Cancer, v. 82, p. 616-17, 1999.

BHATTACHARYA, P.; DUTTAGUPTA, C.; SENGUPTA, S. Proline homozygosity in codon 72 of p53: a risk genotype for human papillomavirus related cervical cancer in Indian. Cancer Lett., Vol. 188, p. 207-211, 2002. 
BIRGANDER, R.; SJALANDER, A.; ZHOU, Z.; FAN, C.; BECKMAN, L.; BECKMAN, G. p53 polymorphisms and haplotypes in nasopharyngeal cancer. Hum Hered., v.46, p. 49-54, 1996.

BOSCH, X.F.; MANOS, M.M.; MUNÕZ, N.; SHERMAN, M.; JANSEN, A.M.; PETO, J.; SCHIFFMAN, M.H., MORENO, K.R.; SHAH, K. Prevalence of human papillomvavirus in cervical cancer: a worldwide perspective. J. Natl. Cancer Inst., Vol. 87, p. 796-802, 1995.

BOSCH, X.F.; DE SANJOSÉ, S.; CASTELLSAGUÉ, X.; MUNÕZ, N. Geographical and social patterns of cervical câncer incidence. In: FRANCO, E.; MONSONEGO, J. editors. New developments in cervical cancer screening and prevention. Boston: Blackwell Science, p. 23-33, 1997.

BOSCH, F.X.; LORINCZ, A.; MUÑOZ, N.; MEIJER, C. J. L. M.; SHAH, K. V. The causal relation between human papillomavirus and cervical cancer. J. Clin. Path., Vol. 55 , p. 244-265, 2002.

BROKER, T.R. Structure and genetic expression of papillomavirus. Obstet. Gynecol. Clin. North Am., Vol. 14, p. 329-347, 1987.

BROWN, D.R.; FIFE, K.H. Human papillomavirus infections of the genital tract. Med. Clin. North Am., Vol. 74, p. 1455-1485, 1990.

BULlER, R.E.; SOOD, A.; FULLENKAMP, C.; SOROSKY, J.; POWILLS, K.; ANDERSON, B. The influence of the p53 codon 72 polymorphism on ovarian carcinogenesis and prognosis. Cancer Gene Ther., v. 4, p. 239-45, 1997.

CABALLERO, O.L. PCR de baixa estringência na discriminação e quantificação de papilomavírus humano. São Paulo; 1998. [Tese de Doutorado - Instituto de Química da Universidade de São Paulo]. 
CAELLES, C.;HELMBERG, A. and KARIN, M. p53-dependent apoptosis in the absence of transcriptional activation of p53-target genes. Nature, v. 370, p. 220-23, 1994.

CALHOUN, E.S.; McGOVERN, R.M.; JANNEY, C.A.; CERHAN, J.R.; ITURRIA, S.J.; SMITH, D.I.; GOSTOUT, B.S.; PERSING, D.H. Host genetic polymorphism analysis in cervical cancer. Clin. Chem., Vol. 48, p. 1218-1224, 2002.

CARGILL, M.; ALTSHULER, D.; IRELAND, J.; SKLAR, P.; ARDLIE, K.; PATIL, N.; SHAW, N.; LANE, C.R.; LIM, E.P.; KALYANARAMAN, N.; NEMESH, J.; ZIAUGRA, L.; FRIEDLAND, L.; ROLFE, A.; WARRINGTON, J.; LIPSHUTZ, R.; DALEY, G.O.; LANDER, E.S. Characterization of single-nucleotide polymorphisms in coding regions of human genes. Nat. Genet., Vol. 22, p. 231-238, 1999.

CHAN, W.K.; KLOCK, G.; BERNARD, H.U. Progesterone and glucocorticoid response elements occur in the long control regions of several human papillomaviruses involved in anogenital neoplasia. J. Virol., v. 63, p. 3261-9, 1989.

CHANG, F.; SYRIANEN, S.; TERVAHAUTA, A.; SYRJANEN, K. Tumourigenesis associated with the p53 tumour suppressor gene. Br. J. Cancer, v. 68, p. 653-61, 1993. CHEN, M.; POPESCU, N.; WOODWORTH, C.; BERNEMAN, Z.; CORBELLINO, M.; LUSSO ABLASHI, D.; DI PAOLO, J. Á. Human herpesvirus 6 infects cervical epithelial cells and trasactivates human papilomavirus gene expression. J. Virol, Vol. 68, p. 1173$1178,1994$.

CHO, Y.; GORINA, S.; JEFFREY, P. and PAVLETICH, N. Crystal structure of a p53 tumour suppressor-DNA complex: understanding tumorigenic mutation. Science, v. 265, p. 346-55, 1994. 
CUZICK, J.; SZAREWSKI, A.; TERRY, G.; HO, L. HANBY, A.; MADDOX, A.M.; KOCJAN, G.; STEELE, S.T.; GUILLEBAUD, J. Human papillomavirus testing in primary cervical screening. Lancet, Vol. 345, p. 1533-1536, 1995.

DELLEO, A.B.; JAY, G.; APPELLA, E.; DUBOIS, G.C.; LAW, L.W.; OLD, I.J. Detection of a transformation-related antigen in chemically induced sarcomas and other transformed cells of the mouse. Proc. Natl. Acad. Sci., Vol. 76, p. 2420-2424, 1979.

DOKIANAKIS, D.N. \& SPANDIDOS, D.A. p53 codon 72 polymorphism as a risk factor in the development of HPV-associated cervical cancer. Mol. Cell Biol. Res. Commun., v. $111-14,2000$.

DONEHOVER, L.A.; HARVEY, M.; SLAGLE, B.L., McARTHUR, C.A.M. Jr.; BUTEL, J.S.; BRADLEY, A. Mice deficient in p53 are developmentally normal but susceptible to spontaneous tumors. Nature, v. 356, p. 215-21, 1992.

DÜRST, M.; DZARLIEVA-PETRUSEVSKA, R.T.; BOUKAMP, P.; FUSENIG, N.E.; GISSMANN, L. Molecular and cytogenetic analysis of immortalized human primary keratinocytes obtained after transfection with human papillomavirus type 16 DNA. Oncogene, 1: 251-56, 1987.

DUTTA, A.; RUPPERT, J.M.; ASTER, J.C.; WINCHESTER, E. Inhibition of DNA replication factor RPA by p53. Nature, Vol. 365, p. 79-82, 1993.

DYBIKOWSKA, A.; DETTLAFF, A.; KONOPA, K.; PODHAJSKA, A. p53 codon 72 polymorphism in cervical cancer patients and healthy women from Poland. Acta Biochim. Pol,. Vol. 47, p. 1179-1182, 2000.

EL-DEIRY, W.S.; KERN, S.E.; PIETENPOL, J.A; KINZLER, K.W.; VOGELSTEIN, B. Definition of a consensus binding site for p53. Nat Genet., Vol. 1, p. 45-49, 1992. 
El-DEIRY, W.; TOKINO, T.; VELCULESCU, V.; LEVY, D.; PARSONS, R.; TRENT, J.; LIN, D.; MERCER, W.; KINZER, K.; VOGELSTEIN, B. WAF1, a potential mediator of p53 tumour suppression. Cell, v. 75, p. 817-25, 1993.

ELIYAHU, D.; RAZ, A.; GRUSS, P.; GIVOL, D.; OREN, M. Participation of p53 cellular tumour antigen in transformation of normal embryonic cells. Nature, Vol. 312, p. 646-649, 1984.

ELIYAHU, D.; MICHALOVITZ, D.; ELIYAHU, S.; PINHASI-KIMHI, O.; OREN, M. Wild-type p53 can inhibit oncogene-mediated focus formation. Proc. Natl. Acad. Sci. Vol. 86, p. 8763-8767, 1989.

EVANDER, M.; EDLUND, K.; GUSTAFSSON, A.; JONSSON, M.; KARLSSON, R.; RYLANDER, E.; WADELL, G. Human papillomavirus infections is transient in young women: a population-based cohort study. J. Infect. Dis., Vol. 171, p. 1026-30, 1995.

FINLAY, C.A.; HINDS, P.W.; LEVINE, A.J. The p53 proto-oncogene can act as a suppressor of transformation. Cell, Vol. 57, p. 1083-1093, 1989.

FRANCO, E.L. Cancer causes revised: human papillomavirus and cervical neoplasia. J. Natl. Cancer Inst., v. 87, p. 779-80, 1995.

FRANCO, E.L.;VILLA, L.L.; RICHARDSON, H.; RONAN, T.; FERENCZY, A. Epidemiology of cervical human papillomavirus infection. In: Franco, E.L. and Monsonego, J. Ed. New Developments in Cervical Cancer and Prevention. WHO/EUROGIN monograph, Blackwell Science, p. 14-22, 1997.

FRANCO, E.L.; VILLA, L.L.; SOBRINO, J.P.; PRADO, J.M.; ROUSSEAU, M.C.; DESY, M.; ROHAN, T.E. Epidemiology of acquisition and clearance of cervical human papillomavirus infection in women from a high-risk area for cervical cancer. J. Infect. Dis., v. 5, p. 1415-23, 1999. 
GIANNOUDIS, A.; GRAHAM, D.A.; SOUTHERN, S.A.; HERRINGTON, C.S. p53 codon $72 \mathrm{ARG} / \mathrm{PRO}$ polymorphism is not related to HPV type or lesion grade in lowand high-grade squamous intra-epithelial lesions and invasive squamous carcinoma of the cervix. Int. J. Cancer, v. 83, p. 66-69, 1999.

GORINA, S.; PAVLETICH, N.P. Structure of the p53 tumor suppressor bound to the ankyrin and SH3 domains of 53BP2. Science, Vol. 274, p. 1001-1005, 1996.

GUSTAFSSON, A.C.; GUO, Z.; HU, X.; AHMADIAN, A.; BRODIN, B.; NILSSON, A.; PONTEN, J.; PONTEN, F.; LUNDEBERG, J. HPV-related cancer susceptibility and p53 codon 72 polymorphism. Acta Derm Venereol. vol. 81, n. 2, p. 125-9, 2001.

HAUPT, Y.; ROWAN, S.; SHAULIAN, E.; VOUSDEN, K.; OREN, M. Induction of apoptosis in Hela cells by transactivation-deficient p53. Gene Dev., v. 9, p. 2170-83, 1995.

HAUPT, Y.; MAYA, R.; KAZAZ, A.; OREN, M. Mdm2 promotes the rapid degradation of p53. Nature, Vol. 387, p. 296-299, 1997.

HAYES, V.M.; HOFSTRA, R.M.; BUYS, C.H.; HOLLEMA, H.; VAN DER ZEE, A.G. Homozygous arginine-72 in wild type p53 and risk of cervical cancer. Lancet, v. 352, p. $1756,1998$.

HELLAND A, LANGEROD A, JOHNSEN H, OLSEN AO, SKOVLUND E, BORRESEN-DALE AL. p53 polymorphism and risk of cervical cancer. Nature, v. 396, p. 530-31, 1998.

HERBST, A.L. The Bethesda system for cervical/vaginal cytologic diagnoses. Clin. Obstet. Gynecol. Vol. 35, p. 22-27, 1992. 
HERNANDEZ-BOUSSARD, T.; RODRIGUEZ-TOME, P.; MONTESANO, R.; HAINAUT, P. IARC p53 mutation database: a relational database to compile and analyze p53 mutations in human tumors and cell lines. International Agency for Research on Cancer. Hum Mutat., Vol. 14, p. 1-8, 1999.

HERSHKO, A. \& CIECHANOVER, A. The ubiquitin system for protein degradation. Annu. Rev. Biochem., v. 61, p. 761-807, 1992.

HILDESHEIM, A.; SCHIFFMAN, M.H.; GRAVITT, P.E.; GLASS, A.G.; GREER, C.E.; ZHANG, T.; SCOTT, D.R.; RUSH, B.B.; LAWLER, P.; SHERMAN, M.E. Persistence of type-specific human papillomavirus infection among cytologically normal women. J. Infect. Dis., v. 169, p. 235-40, 1994.

HILDESHEIM A, SCHIFFMAN M, BRINTON LA, FRAUMENI JF JR, HERRERO R, BRATTI MC, SCHWARTZ P, MORTEL R, BARNES W, GREENBERG M, MCGOWAN L, SCOTT DR, MARTIN M, HERRERA JE, CARRINGTON M. p53 polymorphism and risk of cervical cancer. Nature, v. 396, p. 531-32, 1998.

HILLEBRANDT, S.; STREFFER, C.; DEMIDCHIK, E.P.; BIKO, J.; REINERS, C. Polymorphisms in the p53 gene in thyroid tumours and blood samples of children from areas in Belarus. Mutat. Res., v. 381, p. 201-07, 1997.

HINDS, P.; FINLAY, C. LEVINE, A.J. Mutation is required to activate the p53 gene for cooperation with the ras oncogene and transformation. J. Virol., Vol. 739-746, 1989.

HO, G.Y.; BURK, R.; KLEIN, S.; KADISH, A.; CHANG, C.; PALAN, P.; BASU, J.; TACHEZY, R.; LEWIS, R.; ROMNEY, S. Persistent genital human papillomavirus infection as a risk factor for persistent cervical dysplasia. J. Natl. Cancer Inst., v. 87, p. $1635-71,1995$. 
HOLLSTEIN, M.; RICE, K.; GREENBLATT, M.S.; SOUSSI, T.; FUCHS, R.; SORLIE, T.; HOVIG, E.; SMITH-SORENSEN, B. MONTESANO, R.; HARRIS, C.C. Database of p53 gene somatic mutations in human tumors and cell lines. Nucleic Acids Res. v. 22, p. 3551-5, 1994.

HOWLEY, P.M. Papillomavirinae: the viruses and their replication. In: FIELDS, B.N.; KNIPE, D.M.; HOWLEY, P.M; editors. Fundamental virology, $3^{\text {rd }}$ ed. Philadelphia: Lippincott-Raven; p. 947-977, 1996.

HUANG, T.S.; KUO, M.L.; SHEW, J.Y.; CHOU, Y.W. YANG, W.K. Distinct p53mediated G1/S checkpoint responses in two NIH3T3 subclone cells following treatment with DNA-damaging agents. Oncogene, Vol. 13, p. 625-632, 1996.

HUIBREGTSE, J.M.; SCHEFFNER, M.; HOWLEY, P.M. A cellular protein mediates association of p53 with the E6 oncoprotein of human papillomavirus types 16 or 18 . EMBO J., v. 10, p. 4129-35, 1991.

HUIBREGTSE, J.M.; SCHEFFNER, M.; HOWLEY, P.M. Localization of the E6-AP regions that direct human papillomavirus E6 binding, association with p53, and ubiquitination of associated proteins. Mol Cell Biol., v. 13, p. 4918-27, 1993.

HUIBREGTSE, J.M.; SCHEFFNER, M.; BEAUDENON, S.; HOWLEY, P.M. A family of proteins structurally and functionally related to the E6-AP ubiquitin-protein ligase. Proc. Natl. Acad. Sci., v. 92, p. 2563-7, 1995.

IARC - International Agency for Research on Cancer. Human papillomavirus, Lyon: IARC; (Monographs on the Evaluation of Carcinogenic Risks to humans, Vol. 64, 1995.

IARC - International Agency for Research on Cancer. Human papillomavirus, Lyon: IARC; (Monographs on the Evaluation of Carcinogenic Risks to humans, Vol. 78, 2001. 
INCA - INSTITUTO NACIONAL DO CÂNCER. Estimativas da incidência e mortalidade por câncer no Brasil; Rio de Janeiro, 2000.

INCA - INSTITUTO NACIONAL DO CÂNCER. Estimativas da incidência e mortalidade por câncer no Brasil; Rio de Janeiro, 2002.

IWABUCHI, K.; BARTEL, P.L.; LI, B.; MARRACCINO, R.; FIELDS, S. Two cellular proteins that bind to wild-type but not mutant p53. Proc. Natl. Acad. Sci., Vol. 91, p. 6098-6102, 1994.

JENKINS, J.R.; RUDGE, K.; CURRIE, G.A. Cellular immortalization by a cDNA clone encoding the transformation-associated phosphoprotein p53. Nature, Vol. 312, p. 651654, 1984.

JENKINS, J.R.; CHUMAKOV, P.; ADDISON, C.; STURZBECHER, H.W.; WADEEVANS, A. Two distinct regions of the murine p53 primary amino acid sequence are implicated in stable complex formation with simian virus $40 \mathrm{~T}$ antigen. J Virol., Vol. 62, p. 3903-3906, 1988.

JIANG, M.; MILNER, J. Selective silencing of viral gene expression in HPV-positive human cervical carcinoma cells treated with siRNA, a primer of RNA interference. Oncogene, Vol. 21, p. 6041-6048, 2002.

JIN, X.; WU, X.; ROTH, J.A.; AMOS, C.I.; KING, T.M.; BRANCH, C.; HONN, S.E.; SPITZ, M.R. Higher lung cancer risk for younger African-Americans with the Pro/Pro p53 genotype. Carcinogenesis., v. 16, p. 2205-08, 1995.

JOSEFSSON AM, MAGNUSSON PK, YLITALO N, QUARFORTH-TUBBIN P, PONTEN J, ADAMI HO, GYLLENSTEN UB.p53 polymorphism and risk of cervical cancer. Nature, v. 396, p. 531, 1998. 
KAIANO, J. H. L. Correlação entre o polimorfismo do códon 72 do gene p53 e a presença de DNA de papilomavírus humano (HPV) em carcinoma de pênis. São Paulo, 2000. 74p. Dissertação de Mestrado - Fundação Antônio Prudente.

KANDA, T.; FURUNO, A.; YOSHIIKE, K. Human papillomavirus type 16 open reading frame E7 encodes a transforming gene for rat 3Y1 cells. J. Virol., Vol. 62, p. 610-613, 1988.

KAUR, P.; McDOUGALL, J.K. Characterization of primary human keratinocytes transformed by human papillomavirus type 18. J. Virol., Vol. 62, p. 1917-1924, 1988.

KIM, J.W.; ROH, J.W.; PARK, N.H.; SONG, Y.S.; KANG, S.B.; LEE, H.P. Polymorphism of TP53 codon 72 and the risk of cervical cancer among Korean women. Am. J. Obstet. Gynecol., Vol. 184, n. 2, p. 55-8, 2001.

KIRCHHOFF, M.; ROSE, H.; PETERSEN, B.L.; MAAHR, J.; GERDES, T.; LUNDSTEEN, C.; BRYDORF, T.; KRYGER-BAGGESEN, N.; CHRISTENSEN, L.; ENGELHOLM, S.A.; PHILIP, J. Comparative genomic hybridization reveals a recurrent pattern of chromosomal aberrations in severe dysplasia/carcinoma in situ of the cervix and in advanced-stage cervical carcinoma. Genes Chromosomes Cancer, Vol. 24, p. 144-150, 1999.

KLAES, R.; RIDDER, R.; SCHAEFER, U.; BENNER, A.; VON KNEBEL DOEBERITZ, M. No evidence of p53 allele-specific predisposition in human papillomavirus-associated cervical cancer. J. Mol. Med., v. 77, p. 299-302, 1999.

KLAES, R.; FRIEDRICH, T.; SPITKOYSKY, D.; RIDDER, R.; RUDY, W.; PETRY, U.; DALLENBACH-HELLWEG, G.; SCHMIDT, D.; VON KNEBEL DOEBERITZ, M. Overexpression of p16(INK4A) as a specific marker for dysplastic and neoplastic epithelial cells of the cervix uteri. Int. J. Cancer, Vol. 92, p. 276-284, 2001. 
KLINGELHUTZ, A.J.; FOSTER, S.A.; McDOUGALL, J.K. Telomerase activation by the E6 gene product of human papillomavirus type 16. Nature, Vol. 380, p. 79-82, 1996.

KLUG, S.J.; WILMOTTE, R.; SANTOS, C.; ALMONTE, M.; HERRERO, R.; GUERRERO, I.; CACERES, E.; PEIXOTO-GUIMARAES, D.; LENOIR, G.; HAINAUT, P.; WALBOOMERS, J.M.; MUNOZ, N. TP53 polymorphism, HPV infection, and risk of cervical cancer. Cancer Epidemiol. Biomarkers Prev., Vol. 10, p.1009-1012, 2001.

KO, L.J.; PRIVES, C. p53: puzzle and paradigm. Genes Dev., Vol. 10, p. 1054-1072, 1996.

KOUTSKY, L.A.; HOLMES, K.K.; CRITCHLOW, C.W.; STEVENS, C.E.; PAAVONEN, J.; BECKMANN, A.M.; DeROUEN, T.A.; GALLOWAY, D.A.; VERNON, D.; KIVIAT, N.B. A cohort study of the risk of cervical intraepithelial neoplasia grade 2 or 3 in relation to papillomavirus infection. N. Engl. J. Med., v. 18, p. 1272-8, 1992.

KRCMÁR, M; SUCÁNKOVÁ, A.; KANKA, J.; VONKA, V. Prospective study on the relationship between cervical neoplasia and herpex simplex 2 virus. III. Presence of herpex simplex type 2 antibody in sera of subjects who developed cervical neoplasia later in the study. Int. J. Cancer, Vol. 38, p. 161-165, 1986.

KUCERA, E.; TONG, D.; REINTHALLER, A.; LEODOLTER, S.; ZEILLINGER, R.; SLIUTZ, G. p53 polymorphism at codon 72--does it constitute a risk for squamous intraepithelial lesions and invasive cancer of the cervix in Central Europeans? Wien Klin Wochenschr., vol. 112, n. 18, p. 817-20, 2000.

LANE, D.P.; CRAWFORD, L.V. T antigen is bound to a host protein in SV40 transformed cells. Nature, v. 278, p. 261-3, 1979. 
LANHAM S, CAMPBELL I, WATT P, GORNALL R.P53 POLYMORPHISM AND RISK OF CERVICAL CANCER. Lancet, v. 352, p. 1631, 1998.

LEVINE, A.J.; MOMAND, J. FINLAY, C.A. The p53 tumor suppressor gene. Nature, v. 351, p. $453-6,1991$.

LEVINE, A.J. p53, the cellular gatekeeper for growth and division. Cell, v. 88, p. 323-31, 1997.

LI, X.; COFFINO, P. Identification of a region of p53 that confers lability. J. Biol. Chem., Vol. 271, p. 4447-4451, 1996.

LINZER, D.I.; LEVINE, A.J. Characterization of a 54K dalton cellular SV40 tumor antigen present in SV40-transformed cells and uninfected embryonal carcinoma cells. Cell, Vol. 17, p. 43-52, 1979.

LU, X.; LANE, D.P. Differential induction of transcriptionally active p53 following UV or ionizing radiation: defects in chromosome instability syndromes? Cell, Vol. 75, p. 765-778, 1993.

LU, H.; LEVINE, A.J. Human TAFII31 protein is a transcriptional coactivator of the p53 protein. Proc. Natl. Acad. Sci., Vol. 92, p. 5154-8, 1995.

MACIAG, C.; VILLA, L.L. Genetic susceptibility to HPV infection and cervical cancer. Braz. J. Med. Biol. Res., Vol. 32, p. 915-922, 2000.

MADELEINE, M.M.; SHERA, K.; SCHWARTZ, S.M.; DALING, J.R.; GALLOWAY, D.A.; WIPF, G.C.; CARTER, J.J.; MCKNIGHT, B.; MCDOUGALL, J.K. The p53 Arg72Pro polymorphism, human papillomavirus, and invasive squamous cell cervical cancer. Cancer Epidemiol. Biomarkers Prev., v. 9, p. 225-27, 2000. 
MAGALHÃES, O. Verruga dos bovídeos. Brasil-Médico, Vol. 34, p. 430-431, 1920.

MAGNUSSON, P.K.; SPAREN, P.; GYLLENSTEN, U.B. Genetic link to cervical tumours. Nature, Vol. 400, p. 29-30, 1999.

MAKNI, H.; FRANCO, E.L.; KAIANO, J.; VILLA, L.L.; LABRECQUE, S.; DUDLEY, R.; STOREY, A.; MATLASHEWSKI, G. p53 polymorphism in codon 72 and risk of human papillomavirus-induced cervical cancer: effect of inter-laboratory variation. Int. J. Cancer., v. 87, p. 528-33, 2000.

MALCOLM, E.K.; BABER, G.B.; BOYD, J.C.; STOLER, M.H. Polymorphism at codon 72 of p53 is not associated with cervical cancer risk. Mod. Pathol., v. 13, p. 373-78, 2000 .

MALKIN, D.; LI, F.P.; STRONG, L.C., FRAUMENI, Jr.; NELSON, C.E.; KIM, D.H.; KASSEL, J.; GRYKA, M.A.; BISCHOFF, F.Z.; TAINSKY, M.; FRIEND, S.H. Germ line p53 mutations in a familial syndrome of breast cancer, sarcomas and others neoplasms. Science, v. 250, p. 1233-8, 1990.

MANOS, M.M.; TING, Y.; WRIGHT, D.K.; LEWIS, A.J.; BROKER, T.R.; WOLINSKY, S.M. Use of polimerase chain reaction amplification for the detection of genital human papillomaviruses. Cancer Cells, 7: 209-14, 1989.

MANTOVANI, F.; BANKS, L. The interaction between p53 and papillomaviruses. Semin. Cancer Biol., Vol. 9, p. 387-395, 1999.

MANTOVANI, F.; BANKS, L. The human papillomavirus E6 protein and its contribution to malignant progression. Oncogene, Vol. 20, p. 7874-7887, 2001. 
MARIN MC, JOST CA, BROOKS LA, IRWIN MS, O'NIONS J, TIDY JA, JAMES N, MCGREGOR JM, HARWOOD CA, YULUG IG, VOUSDEN KH, ALLDAY MJ, GUSTERSON B, IKAWA S, HINDS PW, CROOK T, KAELIN WG JR. A common polymorphism acts as an intragenic modifier of mutant p53 behaviour. Nat Genet., Vol. 25, p. 47-54, 2000.

MATLASHEWSKI, G.J.; SCHNEIDER, J.; BANKS, L.; JONES, N.; MURRAY, A.; CRAWFORD, L.V. Human papillomavirus type 16 DNA cooperates with activated ras in transforming primary cells. EMBO J., Vol. 6, p. 1741-1746, 1987.

MATLASHEWSKI, G.J.; TUCK, S.; PIM, D.; LAMB, P.; SCHNEIDER, J.; CRAWFORD, L.V. Primary structure polymorphism at amino acid residue 72 of human p53. Mol. Cell. Biol., v. 7, p. 961-63, 1987 b.

MAY, P. and MAY, E. Twenty years of p53 research: structural and functional aspects of the p53 protein. Oncogene, v. 18, p. 7621-36, 1999.

McDOUGALL, J.K. Imortalization and transformation of human cells by human papillomavirus. Curr. Top. Microbiol. Immunol. Vol. 186, p. 101-119, 1994.

McMURRAY, H.R.; NGUYEN, D.; WESTBROOK, T.F.; McANCE, D.J. Biology of human papillomavirus. Int. J. Exp. Pathol., Vol. 82, p. 15-33, 2001.

MINAGUCHI, T.; KANAMORI, Y.; MATSUSHIMA, M.; YOSHIKAWA, H.; TAKETANI, Y.; NAKAMURA, Y. No evidence of correlation between polymorphism at codon 72 of p53 and risk of cervical cancer in Japanese patients with human papillomavirus 16/18 infection. Cancer Res., v. 58, p. 4585-86, 1998.

MOMAND, J.; ZAMBETTI, G.P.; OLSON, D.C.; GEORGE, D.; LEVINE, A.J. The mdm-2 oncogene product forms a complex with the p53 protein and inhibits p53mediated transactivation. Cell, Vol. 69, p. 1237-1245, 1992. 
MIYASHITA T, REED JC. Tumor suppressor p53 is a direct transcriptional activator of the human bax gene. Cell., v. 80, p. 293-99, 1995

MOREAU, F. and MATLASHEWSKI, G. Molecular analysis of different allelic variants of wildtype human p53. Biochem. Cell. Biol., v. 70, p. 1014-1019, 1992.

MORENO, V.; BOSCH, F.X.; MUNOZ, N.; MEIJER, C.J.; SHAH, K.V.; WALBOOMERS, J.M.; HERRERO, R.; FRANCESCHI, S. Effect of oral contraceptives on risk of cervical cancer in women with human papillomavirus infection: the IARC multicentric case-control study. Lancet, Vol. 359, p. 1085-1092, 2002.

MUNGER, K.; BASILE, J.R.; DUENSING, S.; EINCHTEN, A.; GONZALEZ, S.L; GRACE, M.; ZACNY, V.L. Biological activities and molecular targets of the human papillomavirus E7 oncoprotein. Oncogene, Vol. 20, p. 7888-7898, 2001.

MUNÕZ, N.; BOSCH, F.X. The causal link between HPV and cervical cancer and its implications for prevention of cervical cancer. Bull. Pan. Am. Health Organ., Vol. 30, p. 362-377, 1996.

MUNÕZ, N.; FRANCESCHI, S.; BOSETTI, C.; MORENO, V.; HERRERO, R.; SMITH, J.S.; SHAH, K.V.; MEIJER, C.J.; BOSCH, F.X. Role of parity and human papillomavirus in cervical cancer: the IARC multicentric case-control study. Lancet, Vol. 359, p. 1093-1101, 2002.

NELSON, W.G.; KASTAN, M.B. DNA strand breaks: the DNA template alterations that trigger p53-dependent DNA damage response pathways. Mol. Cell Biol. Vol. 14, p. 1815-1823, 1994.

NGAN, H.Y.; LIU, V.W.; LIU, S.S. Risk of cervical cancer is not increased in Chinese carrying homozygous arginine at codon 72 of p53. Br. J. Cancer., v. 80, p. 1828-29, 1999. 
NGAN, H.Y.; LIU, V.W.; LIU, S.S.; CHENG, D.K., NG, T.Y.; WONG, L.C. Homozygous arginine at codon 72 of p53 has no prognostic significance in cervical cancer. Tumour Biol., Vol. 21, p. 135-138, 2000.

NISHIKAWA, A.; FUJIMOTO, T.; AKUTAGAWA, N.; IWASAKI, M.; TAKEUCHI, M.; FUJINAGA, K.; KUDO, R. p53 Polymorphism (codon-72) has no correlation with the development and the clinical features of cervical cancer. Int. J. Gynecol. Cancer., Vol. 10, p. 402-407, 2000.

NOBBENHUIS, M.A.; WALLBOOMERS, J.M.; HELMERHORST, T.J.; ROZENDAAL, L.; REMMINK, A.J.; RISSE, E.K.; VAN DER LINDEN, H.C.; VOORHORST, F.J.; KENEMANS, P.; MEIJER, C.J. Relation of human papillomavirus status to cervical lesions and consequences for cervical-cancer screening: a prospective study. Lancet, Vol. 354, p. 20-25, 1999.

NUBER, U.; SCHWARZ, S.E.; SCHEFFNER, M. The ubiquitin-protein ligase E6associated protein (E6-AP) serves as its own substrate. Eur. J. Biochem., v. 254, p. 64349,1998 .

O’DONOVAN, M.C.; OEFNER, P.J.; ROBERTS, S.C.; AUSTIN, J.; HOOGENDOORN, B.; GUY, C.; SPEIGHT, G.; UPADHYAYA, M.; SOMMER, S.S.; McGUFFIN, P. Blind analysis of denaturing high-performance liquid chromatography as a tool for mutation detection. Genomics, Vol. 52, p. 44-49, 1998.

OKOROKOV, A.L.; PONCHEL, F.; MILNER, J. Induced N- and C-terminal cleavage of p53: a core fragment of $\mathrm{p} 53$, generated by interaction with damaged DNA, promotes cleavage of the $\mathrm{N}$-terminus of full-length $\mathrm{p} 53$, whereas ssDNA induces C-terminal cleavage of p53.EMBO J., Vol. 16, p. 6008-6017, 1997. 
OLINER, J.D.; PIETENPOL, J.A.; THIAGALINGAM, S.; GYURIS, J.; KINZLER, K.W.; VOGELSTEIN, B. Oncoprotein MDM2 conceals the activation domain of tumour suppressor p53. Nature, Vol. 362, p. 857-60, 1993.

OREN, M.; MALTZMAN, W.; LEVINE, A.J. Post-translational regulation of the 54K cellular tumor antigen in normal and transformed cells. Mol. Cell. Biol. Vol. 1, p. 101$110,1981$.

OWEN-SCHUB, L.; ZHANG, W.W.; CUSACK, J.; ANGELO, L.; SANTEE, S.; FUJIWARA, T.; ROTH, J. DEISSEROTH, A.; ZHANG, W.; KRUZEL, E.; RADINSKY, R. Wild-type human p53 and a temperature-sensitive mutant induce Fas/APO-1 expression. Mol. Cell. Biol. v. 15, p. 3032-40, 1995.

OZBUN, M.A. BUTEL, J.S. Tumor suppressor p53 mutations and breast cancer: a critical analysis.Adv. Cancer Res., v. 66, p. 141, 1995.

PAPANICOLAOU, G.N.; TRAUT, H.F. Diagnosis of uterine câncer by the vaginal smear. New York: Commonwealth Fundation, 1943.

PARADA, L.F.; LAND, H.; WEINBERG, R.A.; WOLF, D.; ROTTER, V. Cooperation between gene encoding p53 tumour antigen and ras in cellular transformation. Nature, Vol. 312, p. 649-51, 1984.

PEGORARO, R.; MOODLEY, J.; NAIKER, S.; LANNING, P.; ROM, L. The p53 codon 72 polymorphism in black South African women and the risk of cervical cancer. BJOG., Vol. 107, n. 9, p. 1164-5, 2000.

PEGORARO, R.J.; ROM, L.; LANNING, P.a; MOODLEY, M.; NAIKER, S.; MOODLEY, J. P53 codon 72 polymorphism and human papillomavirus type in relation to cervical cancer in South African women. Int. J. Gynecol. Cancer. Vol. 12, p. 383$388,2002$. 
PETRY, K.U.; SCHEFFEL, D.; BODE, U.; GABRYSIAK, T.; KÖCHEL, H.; KUPSCH, E.; GLAUBITZ, M.; NIESERT, S.; KÜHNLE, H.; SCHEDEL, I. Celular immunodeficiency enhances the progression of human papillomavirus-associated cervical lesions. Int. J. Cancer, Vol. 57, p. 836-840, 1994.

PIETENPOL, J.; TOKINO, T.; THIAGALINGAM, S.; EL-DEIRY, W.; KINZER, K.; VOLGESTEIN, B. Sequence-specific transcriptional activation is essential for growth suppression by p53. Proc. Natl. Acad. Sci., v. 91, p. 1998-2002, 1994.

PIM, D.; COLLINS, M.; BANKS, L. Human papillomavirus type 16 E5 gene stimulates the transforming activity of the epidermal growth fator receptor. Oncogene, Vol. 7, p. 27 $32,1992$.

PIRISI, L.; YASUMOTO, S.; FELLER, M.; DONIGER, J.; DIPAOLO, J.A. Transformation of human fibroblasts and keratinocytes with human papillomavirus type 16 DNA. J. Virol., Vol. 61, p. 1061-1066, 1987.

PIRISI, L.; CREEK, K.E.; DONIGER, J.; DIPAOLO, J.A. Continuous cell lines with altered growth and differentiation properties originate after transfection of human keratinocytes with human papillomavirus type 16 DNA. Carcinogenesis, Vol. 9 p. 1573$1579,1988$.

PRIVES, C. How loops, beta sheets, and alpha helices help us to understand p53. Cell, v. 78 , p. 543-46, 1994.

REICH, N.C.; OREN, M.; LEVINE, A.J. Two distinct mechanisms regulate the levels of a cellular tumor antigen, p53. Mol. Cell Biol., Vol. 3, p. 2143-2150, 1983. 
REZZA, G.; GIULIANI, M.; GARBUGLIA, A.R.; SERRAINO, D.; CAPPIELLO, G.; MIGLIORE, G.; BRANCA, M.; BENEDETTO, A.; IPPOLITO, G. Lack of association between p53 codon-72 polymorphism and squamous intraepithelial lesions in women with, or at risk for, human immunodeficiency virus and/or human papillomavirus infections. Cancer Epidemiol. Biomarkers Prev., Vol. 10, p. 565-566, 2001.

RICHART, R.M. Cervical intraepithelial neoplasia: a review. Pathol. Annu. Vol. 8, p. 302-328, 1973.

RICHART, R.M. A modified terminology for cervical intraepithelial neoplasia. Obstet. Gynecol., Vol. 75, p. 131-133, 1990.

ROMANCZUK, H.; HOWLEY, P.M.; Disruption of either the E1 or the E2 regulatory gene of human papillomavirus type 16 increases viral immortalization capacity. Proc. Natl. Acad. Sci., Vol. 89, p. 3159-3163, 1992.

ROSENTHAL, A.N.; RYAN, A.; AL-JEHANI, R.M.; STOREY, A.; HARWOOD, C.A.; JACOBS, I.J. p53 codon 72 polymorphism and risk of cervical cancer in UK. Lancet, v. 352, p. 871-72, 1998.

ROUSSEAU, M.C.; FRANCO, E.L.; VILLA, L.L.; SOBRINHO, J.P.; TERMINI, L.; PRADO, J.M.; ROHAN, T.E. A cumulative case-control study of risk factor profiles for oncogenic and nononcogenic cervical human papillomavirus infections. Cancer Epidemiol. Biolmarkers Prev., Vol. 9, p. 469-476, 2000.

ROZENDAAL, L.; WALBOOMERS, J.M.M.; van den LINDEN, J.C.; VOORHORST, F.J.; KENEMANS, P.; HELMERHORST, T.J.M.; BALLEGOOIJEN, M.; MEIJER, C.J.L.M. PCR-based high risk HPV test in cervical cancer screening gives objectives risk assessment of women with cytomorphologically normal cervical smears. Int. J. Cancer, Vol. 68, p. 766-69, 1996. 
RUPPERT, J.M.; STILLMAN, B. Analysis of a protein-binding domain of p53. Mol. Cell Biol., Vol. 13, p. 3811-3820, 1993.

SAIKI, R.K.; GELFAND, D.H.; STOFFEL, S.; SCHARF, S.S.; HIGUCHI, H.; HORN, G.T.; MULLIS, K.B.; ERLICH, H.A. Primer-directed enzymatic amplification of DNA with a thermostable DNA polymerase. Science, Vol. 239, p. 487-97, 1988.

SAKAGUCHI, K.; HERRERA, J.E.; SAITO, S.; MIKI, T.; BUSTIN, M.; VASSILEY, A.; ANDERSON, C.W.; APPELLA, E. DNA damage activates p53 through a phosphorylation-acetylation cascade. Genes Dev., Vol. 12, p. 2831-2841, 1998.

SAKAMURO, D.; SABBATINI, P.; WHITE, E.; PRENDERGAST, G. The polyproline region of p53 is required to activate apoptosis but not growth arrest. Oncogene, v. 15, p.887-98, 1997.

SANGUINETTI, C.J.; DIAS NETO, E.; SIMPSON, A.J.G. Rapid silver staining and recovery of PCR products separeted on polyacrilamide gels. Biotechniques, 17: 3-6, 1994.

SARANATH, D.; KHAN, Z.; TANDLE, A.T.; DEDHIA, P.; SHARMA, B.; CONTRACTOR, R.; SHRIVASTAVA, S.; DINSHAW, K. HPV16/18 prevalence in cervical lesions/cancers and p53 genotypes in cervical cancer patients from India. Gynecol. Oncol., Vol. 86, p. 157-162, 2002.

SCHEFFNER, M.; WERNESS, B.A.; HUIBREGTSE, J.M.; LEVINE, A.J.; HOWLEY, P.M. The E6 oncoprotein encoded by human papillomavirus types 16 and 18 promotes the degradation of p53. Cell, v. 63, p. 1129-36, 1990.

SCHEFFNER, M.; TAKAHASHI, T.; HUIBREGTSE, J.M.; MINNA, J.D.; HOWLEY, P.M. Interaction of the human papillomavirus type $16 \mathrm{E} 6$ oncoprotein with wild-type and mutant human p53 proteins. J. Virol., v. 66, p. 5100-5, 1992. 
SCHEFFNER, M.; HUIBREGTSE, J.M.; VIERSTRA, R.D.; HOWLEY, P.M. The HPV16 E6 and E6-AP complex functions as a ubiquitin-protein ligase in the ubiquitination of p53. Cell, v. 75, p. 495-505, 1993.

SCHIFFMAN, M.H. Recent progress in defining the epidemiology of human papillomavirus infection and cervical neoplasia. J. Natl. Cancer Inst. Vol. 84, p. $394-$ $398,1992$.

SCHIFFMAN, M.H.; BAUER, H.M.; HOOVER, R.N.; GLASS, A.G.; CADELL, D.M.; RUSH, B.B.; SCOTT, D.R.; SHERMAN, M.E.; KURMAN, R.J.; WACHOLDER, S.; STANTON, C.K.; MANOS, M.M. Epidemiologic evidence showing that papillomavirus infection causes most cervical intraepithelial neoplasia. J. Natl. Cancer Inst., v. 85, p.958-64, 1993.

SCHILLER, J.T.; VASS, W.C; VOUSDEN, K.H.; LOWY, D.R. The E5 open reading frame of bovine papillomavirus type 1 encodes a transforming gene. J. Virol., Vol. 57, p. $1-6,1986$.

SCHLECHT, N.F.; KULAGA, S.; ROBITAILlE, J.; FERREIRA, S.; SANTOS, M.; MIYAMURA, R.A.; DUARTE-FRANCO, E.; ROHAN, T.E.; FERENCZY, A.; VILLA, L.L.; FRANCO, E.L. Persistent human papillomavirus infection as a predictor of cervical intraepithelial neoplasia. JAMA., Vol. 286, p. 3106-3114, 2001.

SCHLEGEL, R., PHELPS, W.C.; ZHANG, Y.L.; BARBOSA, M. Quantitative keratinocyte assay detecs two biological activities of human papillomavirus DNA and identifies viral types associated with cervical carcinoma. EMBO J., Vol. 7, p. 3181$3187,1988$. 
SCHNEIDER-GADICKE, A.; SCHWARZ, E. Different human cervical carcinoma cell lines show similar transcription patterns of human papillomavirus type 18 early genes. EMBO J., Vol. 5, p. 2285-2292, 1986.

SCHWARZ, S.E.; FREESE, U.K.; GISSMAN, L.; MAYER, W.; ROGGENBUCK, B.; STREMLAU, A.; ZUR HAUSEN, H. Structure and transcription of human papillomavirus sequences in cervical carcinoma cells. Nature, Vol. 314, p. 111-114, 1985.

SCHWARZ, S.E.; ROSA, J.L.; SCHEFFNER, M. Characterization of human hect domain family members and their interaction with $\mathrm{UbcH} 5$ and UbcH7. J. Biol. Chem., v. 273, p. 12148-54, 1998.

SHAW, P.; FREEMAN, J.; BOVEY, R.; IGGO, R. Regulation of specific DNA binding by $\mathrm{p} 53$ : evidence for a role for O-glycosylation and charged residues at the carboxyterminus. Oncogene, Vol. 12, p. 921-930, 1996.

SHOPE, R.E. Infectious papillomatosis of rabbits. J. Exp. Med., Vol. 58, p. 607-627, 1933.

SJALANDER, A.; BIRGANDER, R.; HALLMANS, G.; CAJANDER, S.; LENNER, P.; ATHLIN, L.; BECKMAN, G.; BECKMAN, L. p53 polymorphisms and haplotypes in breast cancer. Carcinogenesis, Vol. 17, p. 1313-1316, 1996.

SKARKA, K.; VERESS, G.; KONYA, J.; GERGELY, L. Frequency of p53 codon 72 genotypes in human papillomavirus associated squamous intraepithelial lesions and cervical cancer. Anticancer Res. Vol. 19, p. 2377-2379, 1999. 
SKARKA, K.; VERESS, G.; JUHASZ, A.; KONYA, J.; SAPY, T.; SOOS, G.; HERNADI, Z.; GERGELY, L. Integration status of virus DNA and p53 codon 72 polymorphism in human papillomavirus type 16 positive cervical cancers. Anticancer. Res., vol. 20, n. 3B, p. 2161-7, 2000.

SMITH, J.S.; MUNÕZ, N.; HERRERO, R.; ELUF-NETO, J.; NGELANGEL, C.; FRANCESCHI, S.; BOSCH, F.X.; WALBOOMERS, J.M.; PEELING, R.W. Evidence for Chlamydia trachomatis as a human papillomavirus cofactor in the etiology of invasive cervical cancer in Brazil and the Philippines. J. Infect. Dis.. Vol. 185, p. 324-331, 2002.

SMOTKIN, D.; WETTSTEIN, F.O. Transcription of human papillomavirus type 16 early genes in a cervical cancer and a cancer-derived cell line and identification of the E7 protein. Proc. Natl. Acad. Sci., Vol. 83, p. 4680-4684, 1986.

SONODA, Y.; SAIGO, P.E.; BOYD, J. p53 and genetic susceptibility to cervical cancer. J. Natl. Cancer Inst., Vol. 91, p. 557, 1999.

STERN, P.L. Immunity to human papillomavirus-associated cervical neoplasia. Adv. Cancer Res. Vol. 69, p. 175-211, 1996.

STOREY, A. THOMAS, M.; KALITA, A.; HARWOOD, C.; GARDIOL, D.; MANTOVANI, F.; BREUER, J.; LEIGH, I.; MATLASHEWSKI, G.; BANK, L. Role of p53 polymorphism in the development of human papillomavirus-associated cancer. Nature, v. 393, p. 229-34, 1998.

SUAREZ-RINCON, A.E.; MORAN-MOGUEL, M.C.; MONTOVA-FUENTES, H.; GALLEGOS-ARREOLA, M.P.; SANCHEZ-CORONA, J. Polymorphism in codon 72 of the p53 gene and cervico-uterine cancer risk in Mexico. Ginecol. Obstet. Mex. Vol. 70, p. $344-348,2002$. 
TACHEZY, R.; MIKYSKOVA, I.; SALAKOVA, M.; VAN RANST, M. Correlation between human papillomavirus-associated cervical cancer and p53 codon 72 arginine/proline polymorphism. Hum. Genet., v. 105, p. 564-66, 1999.

TENTI, P., VESENTINI, N., RONDO, M., ZAPPATORE, R., MIGILIORA, P. CARNEVALI, L., RANZANI, G. P53 polymorphism does not affect the risk of cervical cancer in patients from northern italy. Cancer Epidemiol. Biomarkers Prev., vol. 9, p. 435-38, 2000.

THIERRY, F.; YANIV, M. The BPV1-E2 trans-acting protein can be either an activator or a repressor of the HPV18 regulatory region. ЕMBO J., Vol. 6, p. 3391-3397, 1987.

THOMAS, M. AND BANKS, L. Inhibition of Bak-induced apoptosis by HPV-18 E6. Oncogene, v. 17, p. 2943-54, 1998.

THOMAS, M.; KALITA, A.; LABRECQUE, S.; PIM, D.; BANKS, L.; MATLASHEWSKI, G. Two polymorphic variants of wild-type p53 differ biochemically and biologically. Mol. Cell Biol., v. 19, p. 1092-100, 1999a.

THOMAS, M.; PIM, D.; BANKS, L. The role of the E6-p53 interaction in the molecular pathogenesis of HPV. Oncogene, Vol. 18, p. 7690-7700, 1999b.

THUT, C.J.; CHEN, J.L.; KLEMM, R.; TJIAN, R. p53 transcriptional activation mediated by coactivators TAFII40 and TAFII60. Science, Vol. 267, p. 100-104, 1995.

TING, Y. \& MANOS, M. Detection and typing of genital human papillomaviruses. In: Innis, M.A.et al. PCR protocols. A guide to methods and applications. Academic Press, Inc. 356-59, 1990. 
TONG, X. \& HOWLEY, P.M. The bovine papillomavirus E6 oncoprotein interacts with paxilin and disrupts the actin cytoesqueleton. Proc. Natl. Acad. Sci., Vol. 94, p. 44124417, 1997.

VAN DUIN, M.; SNIJDERS, P.J.; VOSSEN, M.T.; KLAASSEN, E.; VOORHORST, F.; VERHEIJEN, R.H.; HELMERHORST, T.J.; MEIJER, C.J.; WALBOOMERS, J.M. Analysis of human papillomavirus type $16 \mathrm{E} 6$ variants in relation to p53 codon 72 polymorphism genotypes in cervical carcinogenesis. J. Gen. Virol., v. 2, p. 317-25, 2000.

VAN REGENMORTEL, M.H.V.; FAUQUET, C.M.; BISHOP, D.H.L.; CARSTENS, E.B.; ESTES, M.K.; LEMON, S.M.; MANILOFF, J.; MAYO, M.A.; McGEOCH, D.J.; PRINGLE, C.R.; WICKNER, R.B. Virus taxonomy: seventh report of the International Comité on Taxonomy of Virus. Academic Press, 1999.

VERNON, S.D.; UNGER, E.R.; MILLER, D.L.; LEE, D.R.; REEVES, W.C. Association of human papillomavirus type 16 integration in the E2 gene with poor disease-free survival from cervical cancer. Int. J. Cancer, Vol. 74, p. 50-56, 1997.

VILLA, L.L.; FRANCO, E.L. Epidemiologic correlates of cervical neoplasia and risk of human papillomavirus infection in asymptomatic women in Brazil. J. Natl. Cancer Inst., Vol. 81, p. 332-340, 1989.

VILLA, L.L. Human papillomaviruses and cervical cancer. Adv. Cancer Res., v. 71, p. $321-41,1997$.

VOUSDEN, K.H.; DONIGER, J.; DI PAOLO, JÁ; LOWY, D.R.; The E7 open reading frame of human papillomavirus type 16 encodes a transforming gene. Oncogene Res., Vol. 3, p. 167-175, 1988. 
VOUSDEN, K.H.; LU, X. Live or let die: the cell's response to p53. Nat. Rev. Cancer. Vol. 2, p. 594-604, 2002.

WADDELL, S. AND JENKINS, J.R. Defining the minimal requirements for papilloma viral E6-mediated inhibition of human p53 activity in fission yeast. Oncogene, v. 16, p. 1759-65, 1998.

WALBOOMERS, J.M; JACOBS, M.V.; MANOS, M.M.; BOSCH, F.X.; KUMMER, J.A.; SHAH, K.V.; SNIJDERS, P.J.; PETO, J.; MEIJER, C.J.; MUNOZ, N. Human papillomavirus is a necessary cause of invasive cervical cancer worldwide. J. Pathol., v. 1, p. 12-9, 1999.

WALKER, K.K. AND LEVINE, A.J. Identification of a novel p53 functional domain that is necessary for efficient growth suppression. Proc. Natl. Acad. Sci., v. 96, p. $15335-40,1996$.

WANG, Y.; PRIVES, C. Increased and altered DNA binding of human p53 by S and G2/M but not G1 cyclin-dependent kinases. Nature, Vol. 376, p. 88-91, 1995.

WANG, X.; LIU, Y.; CHOW, L.S; WONG, S.C.; TSAO, S.W.; KWONG, D.L.; WANG, J.; SHAM, J.S.; NICHOLLS, J.M. Cisplatin-induced p53-independent growth arrest and cell death in cancer cells. Int. J. Oncol., Vol. 15, p. 1097-1102, 1999.

WERNESS, B.A.; LEVINE, A.J.; HOWLEY, P.M. Association of human papillomavirus types 16 and 18 E6 proteins with p53. Science, v. 248, p. 76-9, 1990.

WESTON, A.; PERRIN, L.S.; FORRESTER, K.; HOOVER, R.N.; TRUMP, B.F.; HARRIS, C.C.; CAPORASO, N.E. Allelic frequency of a p53 polymorphism in human lung cancer. Cancer Epidemiol. Biomarkers Prev. Vol, 1, p. 481-483, 1992. 
WESTON, A.; PAN, C.F.; KSIESKI, H.B.; WALLENSTEIN, S.; BERKOWITZ, G.S.; TARTTER, P.I.; BLEIWEISS, I.J.; BROWER, S.T.; SENIE, R.T.; WOLFF, M.S. p53 haplotype determination in breast cancer. Cancer Epidemiol. Biomarkers Prev., v. 6, p. 105-12, 1997.

WONG, Y.F.; CHUNG, T.K.; CHEUNG, T.H.; NOBORI, T.; HAMPTON, G.M.; WANG, V.W.; LI, Y.F.; CHANG, A.M. p53 polymorphism and human papillomavirus infection in Hong Kong women with cervical cancer. Gynecol. Obstet. Invest., Vol. 50, p. $60-63,2000$.

WOODWORTH, C.D.; WAGGONER, S.; BARNES, W.; STOLER, M.H.; DI PAOLO, J.Á. Human cervical and foreskin epithelial cells immortalized by human papillomavirus DNAs exhibit dysplastic differentiation in vivo. Cancer Res., Vol. 50, p. 3709-3715, 1990 .

WU, T.C.; TRUJILlO, J.M.; KASHIMA, H.K.; MOUNTS, P. Association of human papillomavirus with nasal neoplasia. Lancet., Vol 341, p. 522-524, 1993.

YAMASHITA, T.; YAGINUMA, Y.; SAITOH, Y.; KAWAI, K.; KURAKANE, T.; HAYASHI, H.; ISHIKAWA, M. Codon 72 polymorphism of p53 as a risk factor for patients with human papillomavirus-associated squamous intraepithelial lesions and invasive cancer of the uterine cervix. Carcinogenesis, Vol. 20, p. 1733-1736, 1999.

YEW, P.R.; BERK, A.J. Inhibition of p53 transactivation required for transformation by adenovirus early 1B protein. Nature, Vol. 357, p. 82-85, 1992.

YLITALO, N.; SORENSEN, P.; JOSEFSSON, A.; FRISCH, M.; SPARÉN, P.; PONTÉN, J.; GYLLENSTEN, U.; MELBYE, M.; ADAMI, H. Smoking and oral contraceptives as risks factors for cervical carcinoma in situ. Int. J. Cancer, Vol. 81, p. $357-365,1999$. 
ZEHBE, I.; VOGLINO, G.; WILANDER, E.; GENTA, F.; TOMMASINO, M. Codon 72 polymorphism of p53 and its association with cervical cancer. Lancet., v. 354, p. 218-19, 1999.

ZEHBE, I.; VOGLINO, G.; WILANDER, E.; DELIUS, H.; MARONGIU, A.; EDLER, L.; KLIMEK, F.; ANDERSSON, S.; TOMMASINO, M. p53 codon 72 polymorphism and various human papillomavirus 16 E6 genotypes are risk factors for cervical cancer development. Cancer Res., vol. 61, n. 2, p. 608-11, 2001.

ZHOU, J.; FRAZER, I.H. Papovaviridae: capsid structure and capsid protein function. In: LACEY, C. editor. Papillomavirus reviews: current research on papillomavirus. London: Leeds University Press; p. 93-100, 1996.

zur HAUSEN, H. Human papillomaviruses and their possible role in squamous cell carcinomas. Curr. Top. Microbiol. Immunol. Vol. 78, p. 1-30, 1977.

zur HAUSEN, H. Papillomavirus infections: a major cause of human cancer. Biochim. Biophys. Acta, v. 1288, p. 55-78, 1996.

zur HAUSEN, H. Papillomaviruses causing cancer: evasion from host-cell control in early events in carcinogenesis. J. Natl. Cancer Inst. Vol. 92, p. 690-698, 2000.

zur HAUSEN, H. Papillomaviruses and cancer: from basic studies to clinical application. Nat Rev Cancer, Vol. 2, p. 342-350, 2002.

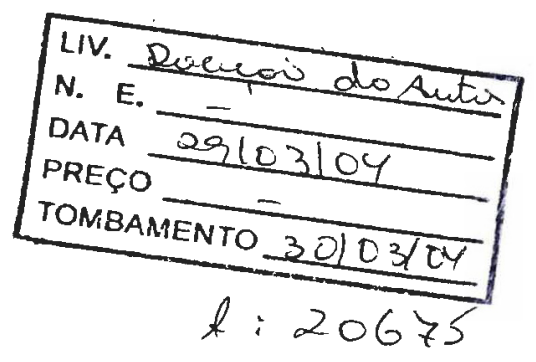

